\title{
Geology and Mineral Deposits of the Miners Gulch Area, Granite County, Montana
}

Gold Placer Deposits and a Molybdenum Anomaly in the Miners Gulch Area, Granite County, Montana

Colluvial Gold Placers Near Miners Gulch, Granite County, Montana

\section{U.S. GEOLOGICAL SURVEY BULLETIN 1791}

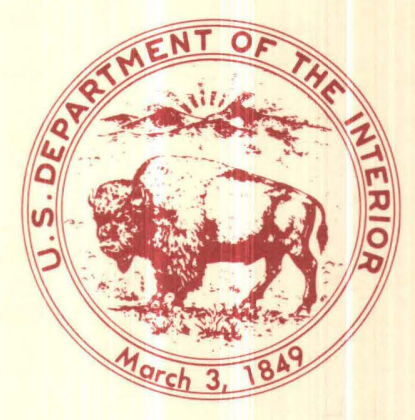





\section{Geology and Mineral Deposits of the Miners Gulch Area, Granite County, Montana}

A. Gold Placer Deposits and a Molybdenum Anomaly in the Miners Gulch Area, Granite County, Montana

By JEFFREY S. LOEN, MICHAEL J. BLASKOWSKI, and JAMES E. ELLIOTT

B. Colluvial Gold Placers

Near Miners Gulch,

Granite County, Montana

BY JEFFREY S. LOEN

This volume is published as chapters A and B.

These chapters are not available separately. 


\section{DEPARTMENT OF THE INTERIOR DONALD PAUL HODEL, Secretary}

U.S. GEOLOGICAL SURVEY

Dallas L. Peck, Director

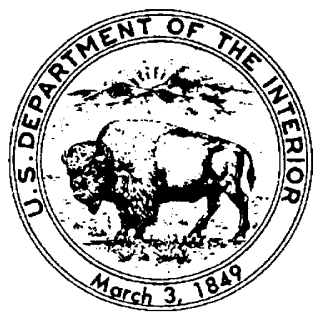

Any use of trade names in this report is for descriptive purposes only and does not imply endorsement by the U.S. Geological Survey.

UNITED STATES GOVERNMENT PRINTING OFFICE: 1989

For sale by the

Books and Open-File Reports Section

U.S. Geological Survey

Federal Center, Box 25425

Denver, CO 80225

\section{Library of Congress Cataloging-in-Publication Data}

Geology and mineral deposits of the Miners Gulch Area, Granite County, Montana.

(U.S. Geological Survey bulletin ; 1791)

Bibliography: $p$.

Includes index.

Contents: Gold placer deposits and a molybdenum anomaly in the Miners Gulch Area, Granite County, Montana / by Jeffrey S. Loen, Michael J.

Blaskowski, and James E. Elliott - Colluvial gold placers near Miners Gulch, Granite County, Montana / by Jeffrey S. Loen.

Supt. of Docs. no.: । 19.3:1791

1. Geology-Montana-Granite County. 2. Mines and mineral resources-Montana-Granite County. I. Blaskowski, Michael J. James E. III. Title. IV. Title: Miners Gulch Area, Granite County, Montana. V. Series.

QE75.B9 no. 1791 
Chapter A

Gold Placer Deposits and a Molybdenum Anomaly in the Miners Gulch Area, Granite County, Montana

BY JEFFREY S. LOEN, MICHAEL J. BLASKOWSKI, and JAMES E. ELLIOTT

U.S. GEOLOGICAL SURVEY BULLETIN 1791 


\section{CONTENTS}

\section{Abstract A1}

Introduction A1

Location and accessibility A2

Topography A2

Climate and vegetation A2

Previous investigations A2

Present investigation A2

Acknowledgments A2

Geologic setting A2

Structure of the Upper Willow Creek valley $\mathbf{A 3}$

Geomorphology A5

Landscape development A5

Piedmont alluvial plains A5

Flood plain A6

Terrace remnants A6

Hills A6

Regional drainage development A6

Local drainage development A7

\section{Lithology A9}

Middle Proterozoic sedimentary rocks A9

Snowslip Formation A9

Mount Shields Formation A9

Bonner Quartzite A9

Cretaceous-Tertiary igneous rocks A9

Miners Gulch stock and related dikes A9

Granodiorite of Miners Gulch A9

Cretaceous or Tertiary porphyritic granodiorite $\mathbf{A 1 0}$

Tertiary dikes and flows $\mathbf{A 1 0}$

Rhyolite A10

Miscellaneous dikes A10

Basalt A11

Cenozoic sedimentary deposits A11

Tertiary deposits A11

Older colluvium A11

Pliocene(?) or lower Quaternary deposits A11

Upper terrace deposits A11

Older fanglomerate $\mathbf{A 1 3}$

Quaternary deposits A13

Lower terrace deposits $\mathbf{A 1 3}$

Younger fanglomerate A13

Alluvium A13

Younger colluvium $\mathbf{A 1 5}$

Geologic history A15

Economic geology A17

History of mining A17

Production A18

Gold placer deposits A18

Types of placer deposits $\mathbf{A 1 8}$

Alluvial placers A18 
Economic geology-Continued

Colluvial placers A18

Terrace deposits A19

Descriptions of mined stream drainages A19

Alder Gulch A20

Niles Gulch A20

Homestake Gulch A20

Unnamed hillside placer A20

Deadwood Gulch A20

Miners Gulch A21

Cowan Gulch A21

Baboon Gulch A21

Coles Gulch A21

Sawpit Gulch A21

Scotchman Gulch A21

Vein deposits and altered areas $\mathbf{A 2 2}$

Stages of veining $\mathbf{A 2 2}$

Alteration A22

Geochemistry A22

Sampling and laboratory procedure A22

Correlation analysis A24

Discussion of geochemical maps A29

Analysis of gold samples $\mathbf{A 3 3}$

Character of gold $\mathbf{A 3 3}$

Electron microprobe study A34

Discussion of characteristics of gold grains $\mathbf{A 3 5}$

Molybdenum anomaly A41

Geophysical studies $\mathbf{A 4 2}$

Discussion of molybdenum anomaly $\mathbf{A 4 3}$

Comparison of molybdenum anomaly to known porphyry

molybdenum deposits $\mathbf{A 4 3}$

Origin of gold placer deposits $\mathbf{A 4 7}$

References cited A50

PLATE

[Piate in pocket]

1. Geologic map and sample localities of part of the Alder Gulch quadrangle, Granite County, Montana

\section{FIGURES}

1. Map showing location of study area and local geologic and geographic features $\mathbf{A 3}$

2. Generalized geologic map of part of the John Long and Sapphire Mountains, Montana A4

3. Benches east of Upper Willow Creek A6

4. North-dipping remnant of Pliocene(?) or early Pleistocene upper terrace deposits, between mouths of Homestake and Niles Gulches A7

5. Longitudinal profiles of streams in study area $\mathbf{A 8}$

6. Schematic representation of stratigraphic relationships of Cenozoic sedimentary deposits in Miners Gulch area $\mathbf{A 1 2}$

7. Stratigraphic column of upper terrace deposits south of Sawpit Gulch A14

8. Stratigraphic column of Quaternary alluvium in Sawpit Gulch A14 
9. Placer workings north of mouth of Alder Gulch A20

10. Map of vein attitudes in study area $\mathbf{A 2 3}$

11. Geochemical distribution of antimony and arsenic from 133 rock samples

12. Geochemical distribution of gold from 133 rock samples $\mathbf{A 3 7}$

13. Geochemical distribution of barium from 133 rock samples $\mathbf{A 3 8}$

14. Geochemical distribution of molybdenum from 133 rock samples A39

15. Geochemical distribution of tungsten from 133 rock samples $\mathbf{A 4 0}$

16. Gold grain with attached quartz crystal from alluvium in gulch south of Sawpit Gulch A41

17. Rounded gold nugget from alluvium in Homestake Gulch $\mathbf{A 4 1}$

18. Wire gold and angular nuggets from placer mine in Upper Sawpit Gulch

19. Wire gold from barite vein south of Sawpit Gulch A41

20. Histogram of gold fineness data, study area $\mathbf{A 4 2}$

21. Graphs showing variations in gold fineness from rims to cores of grains $\mathbf{A 4 3}$

22. Gravity map, John Long and Sapphire Mountains, southwest Montana A45

23. Aeromagnetic map of study area A46

24. East-west geologic cross section through study area in vicinity of Miners Gulch A47

25. Distribution of average fineness of gold grains with fineness $>900$ in streamsediment samples A49

\section{TABLES}

1. Lithologies and estimated frequency of 4-6 in. cobbles in upper terrace deposits $\mathbf{A 1 3}$

2. Lithologies in alluvium in study area based on visual examination of clast lithologies and their characteristics seen in mine tailings of placer-mined stream channels A16

3. Production data for Miners Gulch area and neighboring placer districts A19

4. Semiquantitative spectrographic analyses for selected elements and atomic absorption analyses for gold in grab samples of altered rock or vein A25

5. Atomic absorption analyses for selected elements in grab samples of altered rock or vein A29

6. Semiquantitative spectrographic analyses for selected elements and atomic absorption analyses for gold in panned concentrates of stream-sediment samples A30

7. Semiquantitative spectrographic analyses for selected elements in panned concentrates of stream-sediment samples, fraction magnetic at $\mathbf{0 . 6}$ amperes $\mathbf{A 3 1}$

8. Semiquantitative spectrographic analyses for selected elements in panned concentrates of stream-sediment samples, hand-magnet fraction $\mathbf{A 3 2}$

9. Semiquantitative spectrographic analyses for selected elements in panned concentrates of stream-sediment samples, fraction magnetic at $\mathbf{2 . 0}$ amperes $\mathbf{A 3 2}$

10. Semiquantitative spectrographic analyses for selected elements in panned concentrates of stream-sediment samples, nonmagnetic fraction A33

11. Semiquantitative spectrographic analyses for selected elements in panned concentrates of vein samples $\mathbf{A 3 3}$

12. Semiquantitative spectrographic analyses for selected elements and atomic absorption analyses for gold and fluorine in soil samples A34

13. Positive linear correlation coefficients for pairs of elements from geochemical analyses of rock samples $\mathbf{A 3 5}$

14. Linear correlation coefficients between gold and 24 selected elements $\mathbf{A 3 5}$

15. Fineness ranges for sample types analyzed by electron microprobe 


\title{
Gold Placer Deposits and a Molybdenum Anomaly in the Miners Gulch Area, Granite County, Montana
}

\author{
By Jeffrey S. Loen, Michael J. Blaskowski, \\ and James E. Elliott
}

\section{Abstract}

Mineral occurrences in the Miners Gulch area include placer gold, barite veins, base and precious metal veins, and a molybdenum anomaly. Placer miners, working mainly between 1867 and 1890, mined gold-bearing deposits along 17 linear mi of stream channel. The amount of gold recovered is estimated from the extent of workings mapped in this study at about 2,200 ounces, then worth approximately $\$ 46,000$ at $\$ 20.67$ per fine ounce. At least one lode mine apparently produced a small amount of gold during the $1890^{\prime} \mathrm{s}$. Barite has a low resource potential, and the molybdenum anomaly has not yet been sufficiently investigated to confirm the presence of a porphyry molybdenum system.

Results of geologic and geomorphological mapping, geochemical sampling, and microprobe analyses suggest that the gold placers in the Miners Gulch area formed through Pleistocene erosion and reconcentration of gold from local veins and from fluvial terrace deposits of Pliocene(?) or early Pleistocene age. Stream rejuvenation, apparently caused by the reversal of Upper Willow Creek, resulted in repeated periods of downcutting and aggradation that were responsible for alluvial placer formation. Placer deposits are of three types: alluvial, colluvial, and terrace deposits. Alluvial placers of Quaternary age, which include stream channel, stream terrace, and fanglomerate deposits, were mined most extensively. Colluvial placers of late Pleistocene and Holocene age, typically consisting of stratified deposits of gravel and grus filling depressions between granodiorite outcrops on hillsides, were mined locally. Colluvial placers served as intermediate collectors of placer gold being transported by hillslope processes from the two gold sources on hillslopes to alluvial placers in stream channels. Terrace deposits of Pliocene(?) or early Pleistocene age on hilltops were not mined and apparently contain only small concentrations of gold.

Vein deposits are widespread in the area and result from four stages of veining. From oldest to youngest these stages are: a barren quartz phase, a predominantly sulfide phase, a barite phase, and a quartz-sulfide phase. The quartz-sulfide phase includes a low-temperature association consisting of antimony, arsenic, mercury, and probably gold. The quartz-sulfide phase of veining is the indicated source of low-purity gold (659-900 fine) observed in placers, whereas high-purity gold ( $>900$ fine) in placers appears to have been transported into the area from external sources.

A molybdenum anomaly showing many similarities to known fluorine-deficient, stock-type, calcalkaline porphyry molybdenum deposits exists in the Cretaceous Miners Gulch stock. Concentric zones of anomalous metal values from geochemical samples, and aeromagnetic and gravity lows are centered on a pervasively altered porphyritic granodiorite plug.

\section{INTRODUCTION}

This report appraises the mineral resources of the Miners Gulch area, near Philipsburg, Mont. No previous appraisals have been published, although the area has been familiar to local miners for many years. In the early 1980's, commercial mineral-exploration firms made several surveys of the area. The best-known mineral deposits in the area are gold placer deposits which occur in gulches within the outcrop area of the Miners Gulch stock, a Cretaceous granodiorite.

An integrated approach was used in this appraisal. Geologic mapping determined the distribution of bedrock units, surficial deposits, the extent of placer workings, and the type and occurrences of veins and bedrock alteration. Samples of gold were obtained for electronmicroprobe analysis from placer-mined stream channels, gravel hill cappings, and veins. In addition, extensive geochemical sampling combined with geophysical evidence revealed the presence of a previously unrecognized molybdenum anomaly area near the center of the study area.

Results from this work contribute to resource evaluation of gold in the Butte $1^{\circ} \times 2^{\circ}$ quadrangle, Montana. This study was conducted as part of the U.S. Geological Survey's Conterminous United States Mineral Assessment Program (CUSMAP). 


\section{Location and Accessibility}

The study area is located in and west of the Upper Willow Creek valley, near the center of the John Long Mountains, in Granite County, Mont. (fig. 1). The area encompasses about $21 \mathrm{mi}^{2}$ drained by five principal eastflowing tributaries to Upper Willow Creek. From north to south they are Alder, Niles, Miners, Cowan, and Scotchman Gulches (fig. 1). The center of the study area is $12 \mathrm{mi}$ northwest of Philipsburg, the seat of Granite County.

A graded gravel road, accessible by State Highway 348 west of Philipsburg, skirts the eastern edge of the area. Forest Service roads lead west from this gravel road to Scotchman and Miners Gulches, providing access to the center of the study area. One mining road leads to placer workings in Sawpit Gulch. During field work, several square miles of thickly timbered land to the north and west of these roads were accessible only by foot travel. A gravel road leading north from Miners Gulch was constructed in 1985 .

\section{Topography}

Rugged terrain composed of steep-sided gulches and irregular ridges characterize much of the Miners Gulch area. Sandstone Ridge (fig. 1), at an elevation of $8,272 \mathrm{ft}$, is the highest nearby point. East of Sandstone Ridge, hillsides are composed of pinnacles and spheroidally weathered granodiorite outcrops as high as $140 \mathrm{ft}$. Farther east, near Upper Willow Creek, the topography is more subdued, and smooth, broad surfaces form wide interfluves.

Evidence for glaciation was not seen in the study area, but two small drainages north of the area, Bear and Beaver Creeks, hosted glaciers during Pleistocene time.

\section{Climate and Vegetation}

The climate is characterized by cold, snowy winters and warm, dry summers. Average annual precipitation ranges from 12 to 15 in. Flat areas and south-facing slopes usually host sagebrush or sparse grass, whereas northfacing slopes hold thick stands of conifers. Climax forests, consisting of fir, spruce, and pine were mostly cut during the late 19th century, and a few remaining stands and second-growth fir forests were logged by clearcut methods during the 1960's and 1970's. The Upper Willow Creek flood plain, with the aid of irrigation, supports cattle grazing and commercial alfalfa production.

\section{Previous Investigations}

Little geologic work has been published about the
Miners Gulch area. Lyden (1948) included a brief mention of placer-mining activity in the Upper Willow Creek valley. Hughes $(1970,1971)$ described the petrology and tectonic setting of the Henderson-Willow Creek igneous belt, which includes the Cretaceous Henderson and Miners Gulch stocks and the Eocene volcanics of Willow Creek. In 1975 he suggested that the magma of the Henderson and Miners Gulch stocks was injected into an allochthonous block of Middle Proterozoic Belt sedimentary rocks penecontemporaneously with eastward tectonic transport from the Idaho batholith. Blaskowski and others (1983) described the geology and mineral resources of part of the area covered in this report.

\section{Present Investigation}

During June to September 1982, and in June 1983, about $21 \mathrm{mi}^{2}$ in the Miners Gulch area were mapped and sampled. Mapping and sampling was done chiefly by Loen and Blaskowski. Loen studied Cenozoic stratigraphy, geomorphology, and gold placers. Blaskowski defined the molybdenum anomaly, mapped the altered areas, and interpreted the geochemical data. Elliott visited mines and prospects, examined thin sections of igneous rocks, and analyzed gold with the electron microprobe.

\section{Acknowledgments}

Everett Miller, of Philipsburg, Mont., provided information on and access to active placer workings and claims. Hans Luthje, Charlie Carpp, and Henry Hull offered historical data about early mining days.

M. R. Waters contributed valuable interpretations of soils and geomorphology during several days spent in the field. A. R. Wallace and S. A. Schumm read early drafts of the manuscript and made helpful suggestions. J. J. Connor and W. H. Raymond reviewed the manuscript. This study was conducted as part of the U.S. Geological Survey's Conterminous United States Mineral Assessment Program (CUSMAP).

\section{GEOLOGIC SETTING}

The Miners Gulch area lies in a thrust belt of westcentral Montana that consists of folded and thrust-faulted Proterozoic sediments of the Belt Supergroup that were intruded in Late Cretaceous and early Tertiary time by granite and granodiorite stocks (Ruppel and others, 1981). General geology of the area is shown on figure 2.

Belt metasedimentary rocks and the Cretaceous stocks are cut locally by Tertiary andesitic and rhyolitic dikes and by quartz veins. Eocene andesitic to dacitic volcanic rocks are present in the Rock Creek and Upper Willow Creek valleys. North-trending late Cenozoic basin-range-type faults largely control the valley locations. 


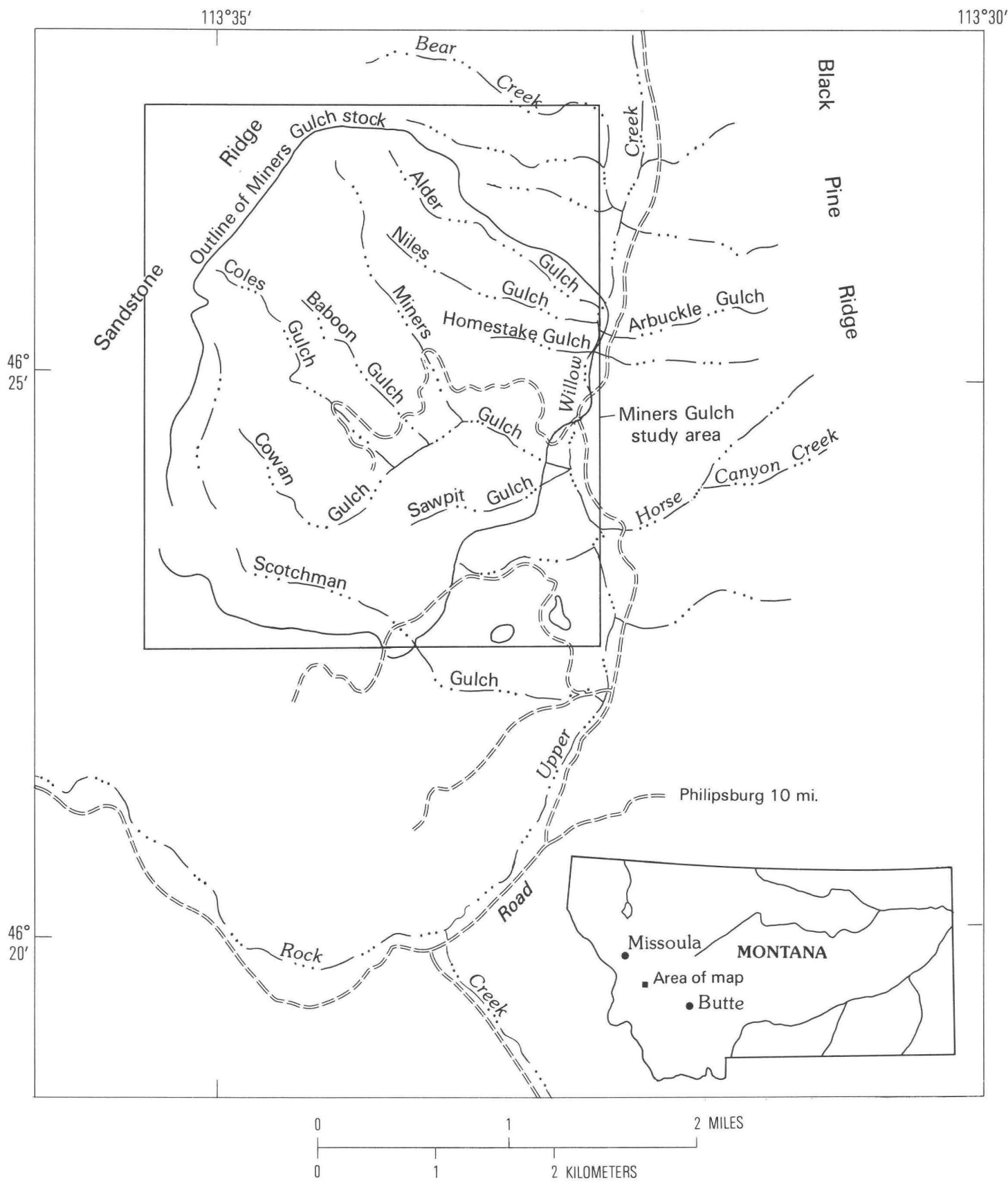

Figure 1. Map showing location of study area and local geologic and geographic features.

Variable thicknesses of Tertiary basin-fill sediments, Pliocene(?) or lower Pleistocene terrace gravels, Pleistocene and Holocene fluvial and glacial deposits, and colluvium locally mantle the older rocks.

\section{Structure of the Upper Willow Creek Valley}

The Upper Willow Creek valley was probably formed in mid-Miocene time when crustal extension caused basin-range-type normal faulting in western Montana (Reynolds, 1979). A zone of normal faulting is present along the east side of the valley, near the topographic break between the benchlands and the mountain front. The location of the fault zone is defined by zones of fault breccia, faceted spurs, phototraces on aerial photographs, and by presumably tectonic joints, trending north and dipping 80 degrees west, parallel to the topographic scarp. Seismic activity has been recorded in this part of the John Long Mountains by the Montana Bureau of Mines and 


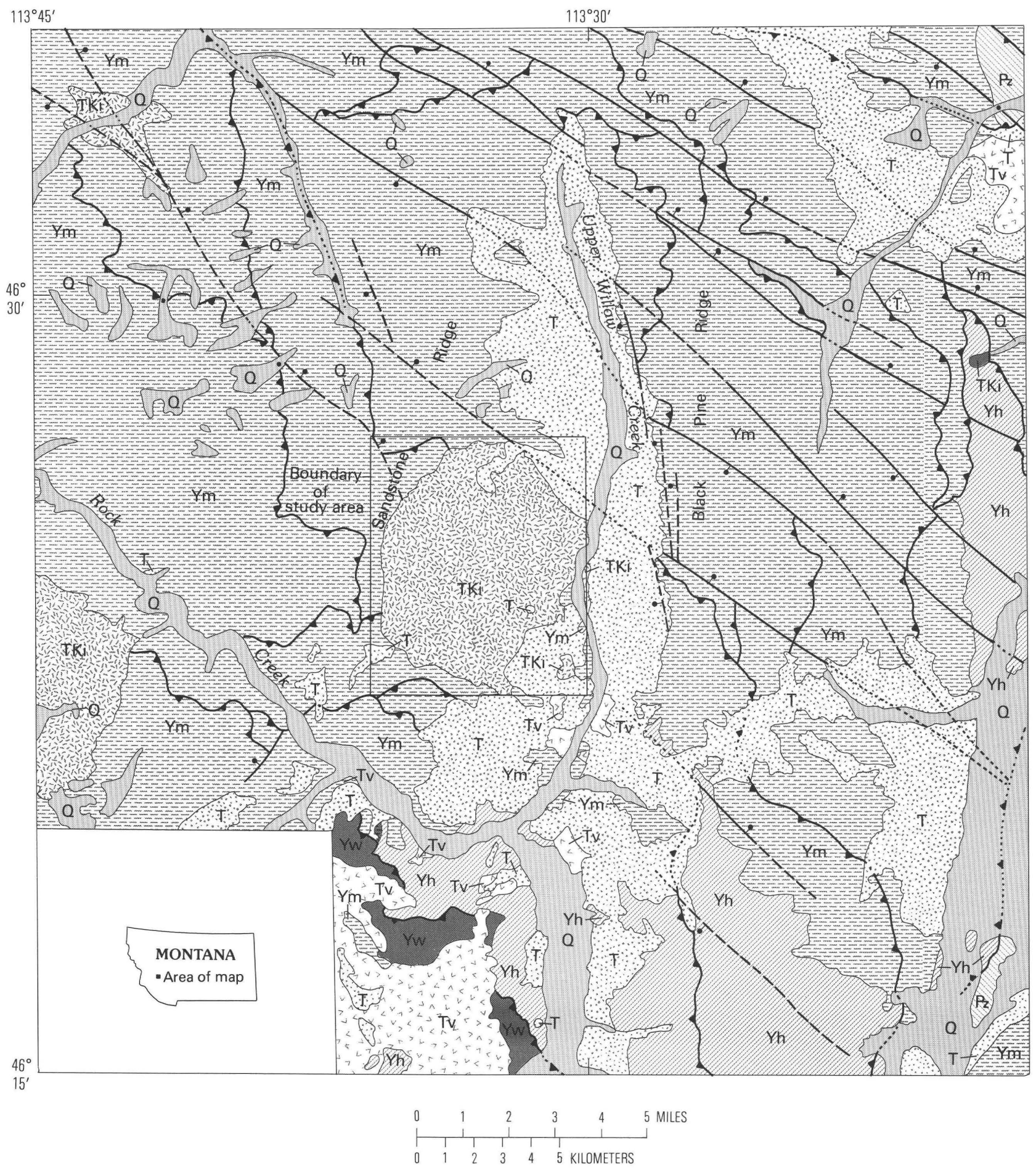

Figure 2 (above and facing page). Generalized geologic map of part of the John Long and Sapphire Mountains, Montana (modified from C. A. Wallace, 1984, unpublished mapping).

Geology (M. Stickney, oral commun., 1983) and may document recent movement along this fault zone. The fault zone has been mapped previously by Pardee (1950), Hughes $(1970,1971)$, and Wallace and others (1981).

Evidence was found during this study that indicates continued tilting of the valley block toward the east, most likely by downdrop along the fault zone on the east side of the valley. Terrace deposits of Pliocene or early Pleistocene age are known only on the west side of the valley, where they tilt east to northeast at 6 to 10 degrees. This 


\section{DESCRIPTION OF MAP UNITS}
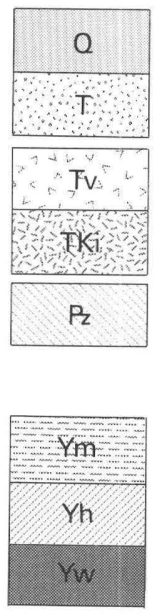

Alluvium, colluvium (Holocene and Pleistocene)

Valley-fill sediments (Tertiary), includes some Quaternary(?) alluvial and colluvial deposits

Volcanic rocks, undivided (Tertiary)

Intrusive igneous rocks, undivided (Tertiary and Cretaceous)

Sedimentary rocks, undivided (Paleozoic)

Belt Supergroup sedimentary rocks (Middle Proterozoic)

Missoula Group

Helena Formation

Wallace Formation

Of same general age

Contact

Thrust fault-Dashed where approximately located, dotted where inferred from stratigraphic information and trace on air photo. Sawteeth on upper plate.

- Fault-Dashed where approximately located, dotted where inferred. Bar and ball on downthrown side.

eastward tilting may be indicated also by attitudes of Eocene volcanic flows of Willow Creek south of the study area (Hughes, 1971, p. 152), many of which dip about 35 degrees toward the east, and Pliocene(?) basalt flows within the study area, which show variable dips to the northeast. The development of benchlands on the east side of the valley and the preservation of Tertiary basinfill sediments beneath the benchlands are also interpreted as evidence for eastward tilting of the valley block during block faulting. The possibility that the valley lies in a graben was considered but could not be confirmed.

Northwest-trending, high-angle normal faults were mapped to the west, north, and east of the study area by Wallace (fig. 2). Wallace (oral commun., 1985) suggested that these faults are long-lived structures perhaps related to movement along the Lewis and Clark Line. Movement on the faults may be pre-Cretaceous, because the faults were not observed by us to cut the Cretaceous Miners Gulch stock.

\section{Geomorphology}

\section{Landscape Development}

The study area is located in the southwestern part of the Upper Willow Creek valley. The Upper Willow Creek valley forms a north-south-trending basin $16 \mathrm{mi}$ long. Its area is about $85 \mathrm{mi}^{2}$. The valley widens from about $1 \mathrm{mi}$ across at the north end to $8 \mathrm{mi}$ wide near the study area and then narrows again to about $2 \mathrm{mi}$ wide at the south end. As discussed previously, faulting has been active on the east side of the valley, and local geomorphic forms are strongly related to it. The main geomorphic elements of the valley consist of piedmont alluvial plains, flood plains, and terrace remnants. The remaining parts of the valley, 60 percent by area, are outcrops of Belt strata, Cretaceous granodiorite, and Tertiary volcanic rocks.

\section{Piedmont Alluvial Plains}

Piedmont plains or "benches," of probable Pliocene or early Pleistocene age, occupy parts of the east side of the Upper Willow Creek valley (fig. 3). They are the most conspicuous geomorphic features in the valley because they are generally barren of trees. The benches slope gently westward from the mountain front toward the present flood plain. The main bench, generally less than $1 \mathrm{mi}$ wide, occupies about $6 \mathrm{mi}^{2}$, or 7 percent of the valley area. This percentage is much less than that of other nearby valleys. Pardee (1950) estimated that benchlands cover an average of 65 percent of the areas of basin-range-type valleys in western Montana.

The main bench is covered by alluvial fan deposits derived from bedrock outcrops directly uphill. The sediment blanket largely obscures underlying deposits, but spurs and isolated hills of Belt strata interrupt the smooth benched surface, and Tertiary(?) basin-fill sedimentary rocks consisting of grayish-green, clay-rich siltstone were seen in an incised tributary near Sheep Gulch. These observations suggest that the deposits represent an aggrading alluvial fan system which filled in between existing bedrock outcrops and covered older basin-fill sediments during sedimentation. Maximum thickness of the bench deposits is estimated to be $200-300 \mathrm{ft}$. The bench superficially resembles a pediment, but the gravels are too thick. According to Bull (1977, p. 223), "fans may be distinguished from pediments as being landforms where the thickness of deposits is more than $1 / 100$ the length of the landform."

Streams flowing across the bench are now deeply incised. Thus, the bench is a relict feature. The deposits were probably laid down in the form of coalescent alluvial fans during Pliocene or early Pleistocene time. At that time the basin-range normal fault on the east side of the valley was active, dropping the valley relative to Black Pine Ridge (fig. 1). Slope degradation processes caused deposition at the base of the fault scarp, and alluvial fans grew westward as fault movement increased slope gradient. Climate during deposition must have been arid, because streams had only enough flow to spread the debris out across the valley, not to transport it out of the valley. Streams incised their courses in early to midPleistocene time, in response to base-level lowering. 


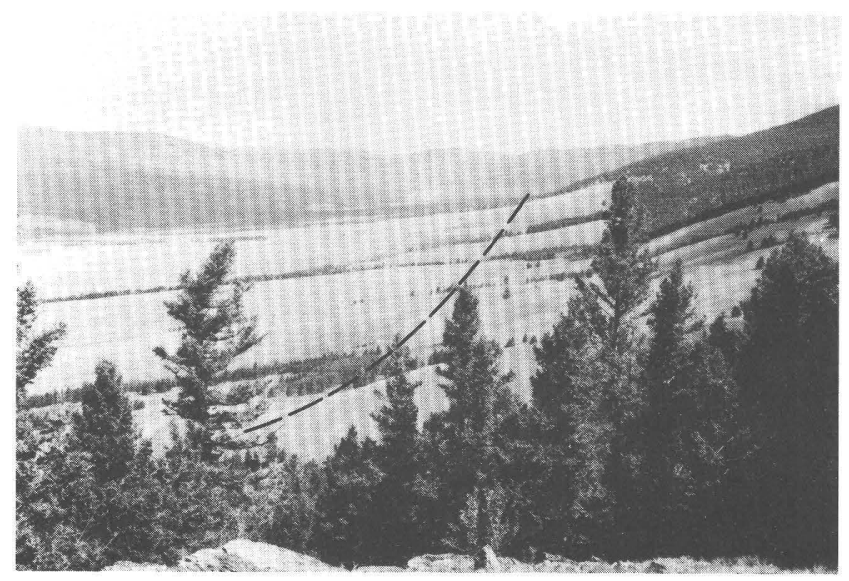

Figure 3. Benches east of Upper Willow Creek. Benches are capped by older fanglomerate, deposited as coalescent alluvial fans that developed along a basin-range normal fault (at break in slope in center of photograph shown by dashed line).

During late Pleistocene and Holocene time the benches were further eroded.

Flood Plain

The Upper Willow Creek flood plain is, for much of its course, a sunken plain occupying a trench cut hundreds of feet below the benches and surrounding hills. In early Pleistocene time the creek probably flowed north, but its flow was later captured by Rock Creek, possibly because of tilting of the Upper Willow Creek valley by block faulting. Details about this drainage disruption are vague, and speculations presented here are based on reconnaissance observations.

Since the postulated reversal, the stream has cut straight down several hundred feet in the area just east of the study area, and even more to the south, near the junction with Rock Creek. Small, indistinct strath terraces were identified in the study area, indicating that the stream cut down almost continually for a long period with no significant pauses during which to cut sideward. Stream terraces in tributary channels and secondary alluvial fans where these side streams meet the Upper Willow Creek valley indicate a complex erosional history related to the present erosion cycle.

\section{Terrace Remnants}

Remnants of two main terraces deposited by Upper Willow Creek cap hills in the study area and occur at other points on the west side of the valley (fig. 4). These terraces are described below as upper and lower terrace deposits (map units QTg and Qg on pl. 1). The terraces are much dissected. Remaining flat areas on the more extensive upper terrace tilt 6-10 degrees to the east, and these terrace deposits define a east-sloping surface when connected in cross section. The younger, lower terrace deposits form a gently eastward sloping surface above Upper Willow Creek. The upper and lower terraces constitute less than 10 percent of the valley's area.

The origin of the terraces is problematical because Upper Willow Creek now has a small catchment area which is hydraulically unable to supply gravels containing large, well-rounded boulders. The lithologic composition of the clasts in both terraces shows that they could not have been derived from the headwaters of the present Upper Willow Creek Valley. Elevations of the terrace segments increase gradually to the south across the study area, indicating a northward paleogradient, and volcanic pebbles found in the upper terrace deposits $2 \mathrm{mi}$ or more northwest of the present outcrop area of the volcanics of Willow Creek also indicate that the terrace was deposited by a north-flowing river.

Hills

Sandstone and Black Pine ridges bound the Upper Willow Creek valley on the west and east sides, respectively. Within the study area, shapes of hills and ridges are controlled mostly by the jointing patterns in the spheroidally weathered granodiorite of the Miners Gulch stock. Hills and ridges are generally asymmetrical, the north-facing slopes being much steeper and more heavily vegetated than the south-facing slopes. In the study area, hill-capping terrace gravels serve as caprock protecting the easily erodable granodiorite beneath. The slopes below these caprocks host colluvium-filled depressions characterized by reworked terrace gravels alternating with layers of granodiorite sand. Some of these colluvial deposits were mined for placer gold.

\section{Regional Drainage Development}

The development of the Rock Creek-Clark Fork drainage system, of which Upper Willow Creek is a part, involved complex and only partly understood interactions among climate, fluvial erosion and bedrock tectonics during mid-Tertiary to mid-Pleistocene time. However, the development of the regional drainage is especially important in the origin of the gold placers and is discussed in the following synthesis, which relies heavily on previously published ideas.

In Eocene to mid-Oligocene time the area of the Rock Creek-Clark Fork system lay near the crest of a regional topographic high now defined by the elevations of many valley floors in southwestern Montana (Reynolds, 1979). According to Reynolds, this regional high was probably related to the crustal arching that affected the northern part of the Great Basin region during late Cenozoic time (Eaton and others, 1978). Regional 


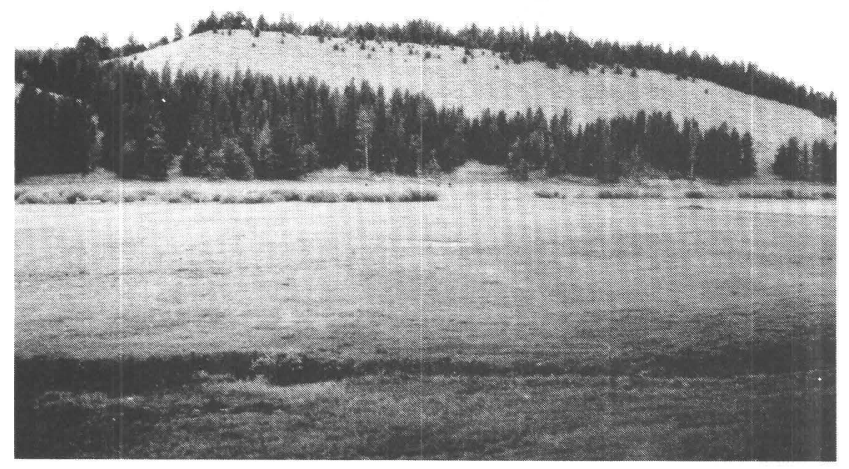

Figure 4. North-dipping remnants of Pliocene(?) or early Pleistocene upper terrace deposits, between mouths of Homestake and Niles Gulches (plate 1). Upper Willow Creek flows from right to left across center of photograph. Terrace is capped by $10-20 \mathrm{ft}$ of coarse gravel.

drainage in the area of the present Rock Creek system was most likely consequent to the north. For example, Miocene strata deposited in the Deer Lodge, Flint Creek, and Blackfoot basins contain arkosic material which could only have been deposited by streams flowing northwestward away from the Boulder batholith (Rasmussen, 1973).

Atwood (1916) first described peculiarities in the drainage system of western Montana and attempted to explain them. He saw the drainage development as the product of four cycles of erosion producing a series of peneplains. Alt and Fields (1971) suggested that for much of the Tertiary a well-integrated drainage net probably did not exist, and basins drained internally until the climate was wet enough to establish through-going streams. The distribution of Tertiary sediments in the region (Wallace and others, 1981), which does not define discrete drainageways, tends to support the Alt and Fields hypothesis. When the climate became wet, in early Pleistocene time, water must have ponded until it overflowed at the lowest point in the valley and cut a new outlet for each basin.

Fluvial deposits remaining from the ancestral drainage system are found on drainage divides, such as north of the Upper Willow Creek valley, and at Marshall Creek Pass, $6 \mathrm{mi}$ southeast of the study area. Antweiler (U.S. Geological Survey, 1980) found gold distributed throughout a veneer of Tertiary gravels with thicknesses of 30-100 ft or more that blanketed parts of the Sapphire Range. Similar evidence of major drainage diversions in surrounding areas of Idaho and Montana was discussed by Atwood (1916), Capps (1941), Anderson (1947), and Ruppel (1967).

The evidence thus suggests that, before extensive downcutting began in Pleistocene time, a series of major north-flowing rivers discharged into the ancestral Clark Fork River. These rivers drained-from east to westthe Deerlodge valley, the Flint Creek valley, the Upper Willow Creek valley, and the Rock Creek valley. After drainage reversal, Upper Willow Creek became a beheaded, underfit stream, tributary to Rock Creek.

\section{Local Drainage Development}

Tributary streams in the Upper Willow Creek valley show different drainage patterns that depend mainly upon underlying host rock types and the part of the valley considered. Streams draining the broad east bench have parallel, roughly equally spaced courses running down the bench. These consequent streams developed because of the sloping ground surface on the bench and were later incised.

Streams within the study area, however, have a more complicated history because of the presence of the Miners Gulch stock and because of eastward tilting. The area occupied by the stock was covered by alluvium probably laid down by north-flowing rivers in early Pleistocene time. However, in early- to mid-Pleistocene time this river reversed, and the southward-flowing drainage developed. The base level of the consequent streams in the study area was lowered at this time, and the streams cut through the terrace deposits into the granodiorite. Strong jointing in the granodiorite caused streams to follow the internal structure of the stock, and the drainage pattern began to change from consequent to subsequent. The present drainage in the study area shows elements of both patterns. In the center of the outcrop area of the stock, however, the pattern is dominated by rectangular, jointcontrolled segments that trend N. $60^{\circ} \mathrm{E}$. and N. $30^{\circ} \mathrm{W}$.

The process of drainage incision probably proceeded episodically, with erosion and deposition concentrated on different stream segments at different times. These processes left a complex terrace stratigraphy within the local stream valleys. During this time, alluvial placer deposits began to form through the repeated reworking of alluvium (Adams and others, 1978).

Streams in the Miners Gulch area display distinctly scalloped longitudinal profiles (fig. 5), probably related to these Pleistocene erosional cycles. These concaveupward profiles, shown in the lower sections of the placermined stream channels on figure 5, may represent the most recent of a series of headward-progressing, downcutting cycles.

Repeated incision of the late Pleistocene and Holocene alluvial fans located at the mouths of gulches probably contributed to concentration of gold in the fans, as shown experimentally by Macke (1977), and by Schumm (1978).

As discussed in the section on Quaternary alluvium 

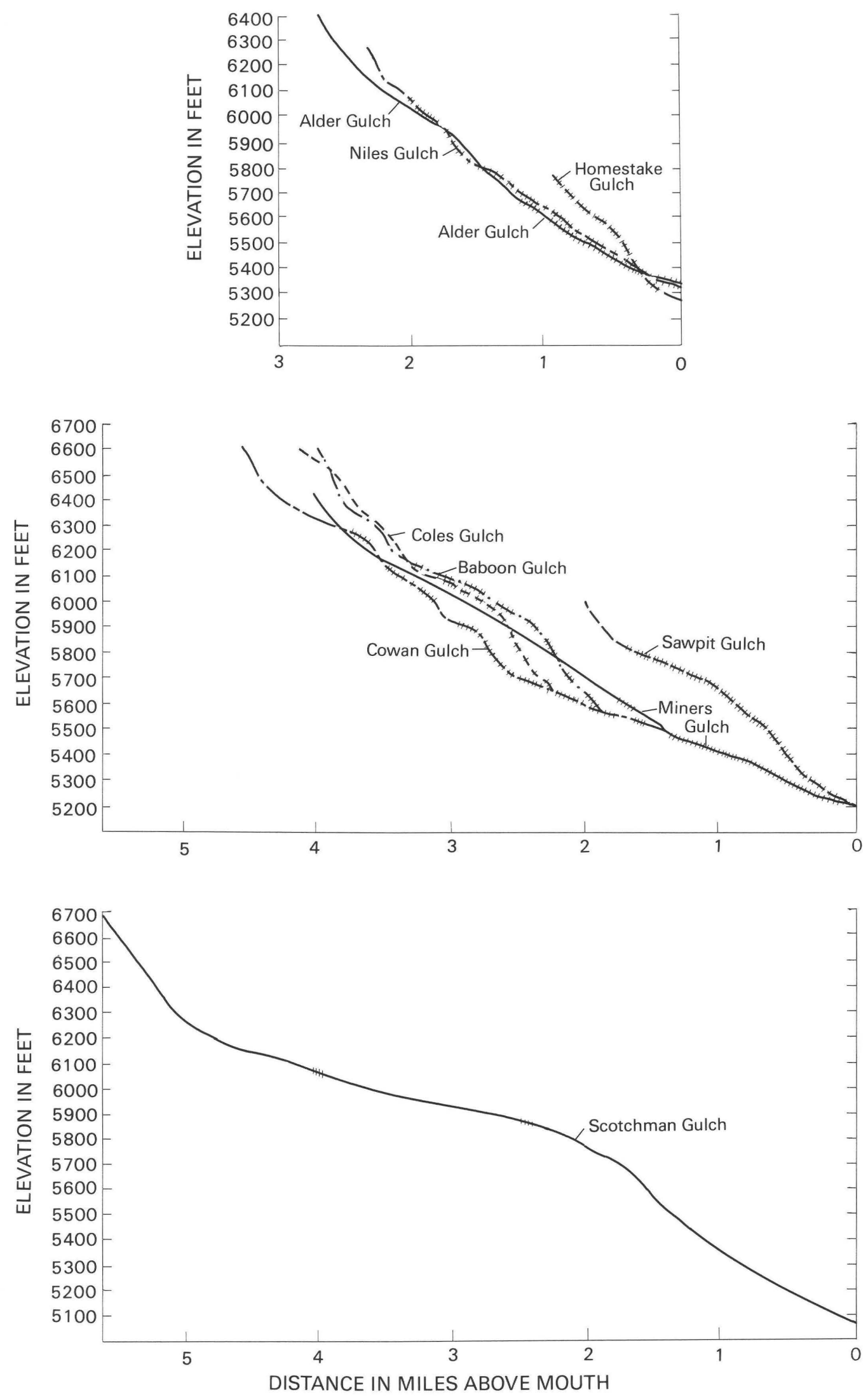

Figure 5. Longitudinal profiles of streams in study area. Hachures indicate placer-mined sections of stream channel (shown in plate 1). Note strongly scalloped profiles. 
below, a change in climate is suggested by the upwardfining sequences seen in the alluvium. The Wisconsin glaciation must have been a time of active streamflow during which much of the present alluvium was reworked. Since then, the sluggish streams have done little to alter their deposits or to change their courses.

\section{Lithology}

\section{Middle Proterozoic Sedimentary Rocks}

The mountains of the John Long Range, including Sandstone and Black Pine ridges (which bound the Upper Willow Creek valley), are underlain mainly by rocks of the Belt Supergroup. These rocks in the Upper Willow Creek valley belong to the Middle Proterozoic Missoula Group, and include, from oldest to youngest the Snowslip, Mount Shields, and Bonner Formations. The following descriptions were furnished in part by C. A. Wallace (written commun., 1982).

\section{Snowslip Formation}

The Snowslip Formation (map unit Ysn) is composed mainly of interbedded red, purple, and green argillite. Reddish argillaceous siltite and tan fine-grained quartzite may also be found. The argillites commonly show well-preserved sedimentary structures including mud cracks, ripple marks, salt casts, and water-expulsion structures. Crossbedding is common in quartzites. The formation occurs in two small areas along the south edge of the map area. Total thickness is not known in the study area, but is $3,600 \mathrm{ft}$ elsewhere in the Butte $1^{\circ} \times 2^{\circ}$ quadrangle.

\section{Mount Shields Formation}

The Mount Shields Formation is composed largely of quartzite and is subdivided into three members. The lower member (map unit Ymsl) consists of white, tan, or dark-grayish-black, fine- to medium-grained quartzite interbedded with thinly laminated argillite. The quartzite is generally mature with well-sorted and very well rounded sand grains. Quartzite beds, typically as thick as 4 in., may show tangential and tabular crossbeds whereas argillite contains ripple marks. The generally black argillite occurs as beds 0.5-1.0 in. thick. Several outcrops of quartzite and argillite along the eastern side of the Miners Gulch stock were mapped as the lower member. Outside the study area the member attains thicknesses of $3,000-3,600 \mathrm{ft}$.

The middle member (map unit Ymsm) is a tan, reddish-pink and gray-black, fine- to medium-grained, well-indurated feldspathic quartzite. It contains well-sorted, subangular to subrounded grains, and shows planar crossbeds. In the Miners Gulch stock this unit forms xenoliths ranging from 30 to $300 \mathrm{ft}$ in length, and also crops out along Sandstone Ridge, northwest of the map area. Its thickness outside of the study area commonly ranges from 3,600 to $5,200 \mathrm{ft}$.

Fine-grained sandstone and interbedded red argillite compose the upper member (map unit Ymsu). The member was tentatively identified in the northern section of the map area, based on float. The upper member is $3,000 \mathrm{ft}$ thick elsewhere in the Butte $1^{\circ} \times 2^{\circ}$ quadrangle.

\section{Bonner Quartzite}

The Bonner Quartzite (map unit Ybo) is a ridgeforming conglomeratic quartzite which is well exposed along Sandstone Ridge. The formation contains chiefly pale-pink, buff and purple feldspathic quartzite. Grains are well to very well rounded and range in size from medium-grained sand to pebbles. Pink and purple planar cross laminations about 0.25 in. thick are common. Chalky white feldspar grains are ubiquitous and, along with quartz, form the sand-sized matrix in pebble conglomerates. Outcrops along Sandstone Ridge form felsenmeer and huge talus slopes. Maximum thickness of the Bonner in the Butte $1^{\circ} \times 2^{\circ}$ quadrangle is $1,200 \mathrm{ft}$.

\section{Cretaceous-Tertiary Igneous Rocks}

Igneous rocks underlie most of the study area. The Cretaceous Miners Gulch stock and associated granodiorite porphyry dikes are the oldest and largest of the igneous units. A porphyritic granodiorite plug and related dacite porphyry dikes (unit TKpg) are of Late Cretaceous or Tertiary age. Younger igneous rocks, of early Tertiary age, include rhyolite porphyry dikes, and miscellaneous dikes (including andesite porphyry, diorite, leuco-quartz monzodiorite, and syeno-granite). Small outcrops of Pliocene(?) basalt represent the youngest igneous unit in the map area.

\section{Miners Gulch Stock and Related Dikes}

Granodiorite of Miners Gulch.-The Miners Gulch stock (map unit Kgd) chiefly consists of medium- to lightgray, medium-grained, hornblende-biotite granodiorite. The stock, however, varies from quartz monzodiorite to granodiorite to monzogranite, based upon modal analyses. According to Hughes (1971, p. 41-48), this variation indicates compositional zoning within the pluton. The stock and related dikes underlie a total of $18-20 \mathrm{mi}^{2}$.

The granodiorite is generally equigranular but is locally porphyritic, containing coarse phenocrysts of 
plagioclase and coarse glomerocrysts of biotite and hornblende. Texturally, the rock is hypidiomorphic to allotriomorphic granular. Hornblende, potassium feldspar, and plagioclase are subhedral to anhedral. Quartz content ranges between 15 and 30 volume percent. Plagioclase is the dominant feldspar, although in a few specimens examined the plagioclase/potassium feldspar ratio approaches unity. Accessory minerals include sphene, apatite, zircon, and magnetite. Actinolite (after hornblende), chlorite, sericite, and epidote are common secondary minerals.

Longitudinal joints within the stock are widespread and are nearly orthogonal. Orientation of one joint set averages N. $60^{\circ} \mathrm{E}$. and dips from $75^{\circ}$ northwest to $80^{\circ}$ southeast. A second set averages N. $30^{\circ} \mathrm{W}$. in orientation and generally dips $60^{\circ}$ southwest. Flat-lying, marginal, parallel shear, and diagonal joints have also been recognized (Hughes, 1971, p. 11-16), but they are rare. Intense weathering along joints has resulted in spheroidally weathered outcrops.

The Miners Gulch stock was emplaced into Missoula Group sedimentary rocks. The stock is thought to be of Late Cretaceous age (70.6 m.y., based on K-Ar biotite dating by Hughes, 1975). Along the contact zone, the sedimentary rocks are contact metamorphosed. These rocks show diverse attitudes, attributed to warping of the strata by injection of magma along bedding planes, or, locally, by rafting of large blocks.

Xenoliths of sedimentary rocks are of two lithologic types: strongly recrystallized, feldspathic quartzite with chalky feldspars, and black, spotted hornfels of metamorphosed red argillaceous sedimentary rock. Most of the xenoliths are considered to be derived from the Mount Shields Formation, but some may be from the Snowslip or Bonner Formations.

Granodiorite porphyry to dacite porphyry dikes locally cut the granodiorite stock, but these dikes were not mapped separately. These dikes are generally light gray and are less than $10 \mathrm{ft}$ thick. The dikes contain abundant mafic minerals (mainly biotite and magnetite) and also contain allanite, apatite, sphene, chlorite, and epidote. Phenocrysts $0.5-3.0 \mathrm{~mm}$ in length are set in a very fine grained groundmass. The abundant biotite and magnetite in the dikes suggest a relationship to the granodiorite stock rather than to a later porphyritic granodiorite plug (map unit TKpg).

Cretaceous or Tertiary porphyritic granodiorite.The granodiorite plug mentioned above (map unit TKpg) and related dikes cut the Miners Gulch stock in secs. 29 and 30, T. $8 \mathrm{~N}$., R. $15 \mathrm{~W}$. The plug crops out within a 0.5 -mi-diameter area, nearly circular in plan. It is probably steep sided and cylindrical because it is not exposed in deep gulches to the south or west.

The granodiorite is light gray to white, seriate to weakly porphyritic, fine to medium grained, and exhibits allotriomorphic-mosaic to sutured texture. The rock contains conspicuous quartz-eye phenocrysts and is easily differentiated from the enclosing granodiorite of Miners Gulch by the paucity of mafic minerals. Quartz, plagioclase, and lesser potassium feldspar constitute the bulk of this rock. Accessory minerals include apatite, zircon, and magnetite. Secondary minerals include sericite, leucoxene, rutile, limonite, and topaz, and possibly some quartz. The granodiorite plug and the related dikes all show strong propyllitic, argillic, and sericitic alteration.

A seriate to porphyritic granodiorite dike in sec. 30, T. 8 N., R. 15 W., and a dacite-porphyry dike in sec. 29 , T. 8 N., R. 15 W., are thought to be associated with the granodiorite plug. The seriate to porphyritic dike is virtually identical to the main body of the porphyritic granodiorite plug, whereas the dacite porphyry contains as much as 45 volume percent phenocrysts of quartz and altered plagioclase. Accessory to the quartz and plagioclase are sericite and rutile. Zircon and apatite comprise the suite of secondary minerals.

The plug is assigned a Cretaceous or Tertiary age because it intrudes the Upper Cretaceous granodiorite stock, and the stock was apparently truncated by erosion preceding deposition of the nearby volcanics of Willow Creek in late Eocene time.

\section{Tertiary Dikes and Flows}

Rhyolite.-Rocks mapped as Tertiary rhyolite (map unit $\mathrm{Tr}$ ) are recognized only in the eastern part of the Miners Gulch area, and include light- to medium-gray rhyolite dikes and one monzogranite dike. The dikes are 10-20 ft thick and dip steeply, often forming prominent ridges in the surrounding Cretaceous granodiorite or in the Bonner Quartzite. All rhyolite dikes show moderate to strong sericitic alteration.

The rhyolite dikes are porphyritic, containing between 20 and 25 volume percent phenocrysts of plagioclase, biotite, and partially resorbed quartz. These phenocrysts are set in an allotriomorphic granular groundmass of quartz and potassium feldspar. Accessory minerals include magnetite, zircon, and apatite. Secondary minerals are muscovite, sericite, iron-oxide minerals, rutile, and undifferentiated clay minerals.

The monzogranite dike has a generally aplitic texture, containing sparse phenocrysts of plagioclase. It also contains accessory magnetite, zircon, sericite, and undifferentiated clay minerals.

Miscellaneous dikes.-These include dikes (map unit Td) of medium- to dark-gray andesite and rare diorite, monzodiorite, and syeno-granite dikes which range from $5-10 \mathrm{ft}$ in thickness. The dikes of Tertiary age were seen cutting only the granodiorite of Miners Gulch, and they typically trend northeast.

The andesite is slightly to moderately porphyritic, 
and contains as much as 15 volume percent phenocrysts of altered hornblende and plagioclase, and lesser amounts of quartz and biotite set in a pilotaxitic groundmass. Hornblende is zoned, with dark-green cores and lightgreen rims in some specimens. Common accessory minerals are magnetite, apatite, allanite, and sphene. Secondary minerals, some of which are the result of strong propyllitic alteration, include sericite, epidote, biotite, chlorite, actinolite-tremolite, sphene, leucoxene, and various iron-oxide minerals.

A diorite dike occurs in SE $1 / 4 \mathrm{sec} .6, \mathrm{~T} .7 \mathrm{~N}$., R. $15 \mathrm{~W}$. It is hypidiomorphic granular to slightly porphyritic. Primary minerals include quartz, plagioclase (mostly oligoclase), and hornblende. Accessory minerals are monazite and apatite. Secondary minerals include sericite, epidote, sphene, actinolite and tremolite (after hornblende), and clay minerals.

A leuco-quartz monzodiorite dike occurs in the SE $1 / 4$ sec. 19, T. $8 \mathrm{~N}$., R. $15 \mathrm{~W}$. This rock has a hypidiomorphic-granular texture and is composed mainly of albite and poikilitic potassium feldspar.

A syeno-granite dike occurs in the SW $1 / 4 \mathrm{sec} .20$, T. $8 \mathrm{~N}$., R. $15 \mathrm{~W}$. The dike has an allotriomorphicgranular texture and is composed mainly of quartz, poikilitic microcline, plagioclase (albite to oligoclase), augite, and tremolite.

Basalt.-Remnants of Pliocene(?) basalt flows (map unit $\mathrm{Tb}$ ) are exposed in two areas in the extreme southern section of the map area. The flows, apparently tens of feet thick and tilted moderately northeast, lie upon an erosional surface cut into granodiorite and are overlain by fluvial gravel of Pliocene or early Pleistocene age.

The basalt is dark gray, weathers to a dark brownish black, and shows weakly developed flow layering. Layering is defined by elongated and aligned vesicles as well as by tabular jointing. The basalt is porphyritic. Phenocrysts comprise 20-25 volume percent and are mainly hypersthene, augite, plagioclase (more than 50 percent anorthite) and altered olivine set in a pilotaxitic groundmass. Clinopyroxene and orthopyroxene are approximately equal in abundance. The only major accessory mineral is magnetite. Iron-oxide minerals and iddingsite(?) after olivine comprise a limited suite of secondary minerals.

In western Montana, basalts of Pliocene age are common in valleys controlled by basin-range normal faults (Reynolds, 1979). These basalts are thought to have erupted along normal faults, which tapped magma sources during Pliocene extension and doming. Because these Pliocene basalts in western Montana lie on an uncomformity of early to mid-Tertiary age, the basalts exposed within the study area and a few miles to the south may be also of Pliocene age and may be related to Pliocene block-faulting that happened during the formation of the Upper Willow Creek valley.

\section{Cenozoic Sedimentary Deposits}

Seven Cenozoic sedimentary deposits, all unconsolidated surficial units, were recognized in the Miners Gulch area chiefly on the basis of geomorphic position (fig. 6). Five of these are fluvial deposits ranging in age from Pliocene(?) or early Pleistocene to Holocene. These include the upper and lower terrace deposits, older fanglomerate, younger fanglomerate, and alluvium. The two remaining Cenozoic deposits are colluvial, and include older colluvium of Pliocene(?) age and younger colluvium of late Pleistocene and Holocene age.

\section{Tertiary Deposits}

Older colluvium. - A poorly sorted, unconsolidated deposit (map unit Tc) composed of angular gray quartzite caps two hills south of Sawpit gulch. The origin of the deposit is obscure, but it shows features that suggest gravity transport (possibly by a landslide) that occurred relatively close to the source of the quartzite.

Limited exposures of the deposit in roadcuts showed angular boulders suspended in a fine-grained matrix, typical of landslide deposits. No frameworksupported deposits were seen. The only lithology present in the deposit is a white to gray, fine- to medium-grained feldspathic quartzite containing distinctive black heavymineral laminations. This lithology is probably part of the Belt Supergroup, but the formation to which it belongs is undetermined.

The top of the deposit is a rather flat surface with hills and swales of about $10 \mathrm{ft}$ in vertical relief. The surface is littered with angular boulders of the gray quartzite, and a few split, sub-rounded red feldspathic quartzite boulders were found, suggesting a cap of terrace deposits. If so capped, the underlying landslide debris is older than early Pleistocene.

\section{Pliocene(?) or Lower Quaternary Deposits}

Upper terrace deposits.-Gravelly alluvium (map unit QTg) comprised chiefly of rounded feldspathic quartzite cobbles in sandy clay matrix was mapped throughout the study area, capping hilltops within the outcrop area of the Miners Gulch stock. Most of this alluvium has been derived from feldspathic sandstones and quartzites whose sources may have been the Belt Supergroup or Paleozoic formations in surrounding regions.

The deposits, as seen on hills in secs. 6 and 7, T. 7 N., R. 15 W., consist of subangular to subrounded quartzite cobbles generally $2-6$ in. in diameter, and boulders locally as much as $3 \mathrm{ft}$ in diameter. Feldspathic quartzites containing an estimated 5-20 percent of white feldspar grains are widespread. The most common colors 

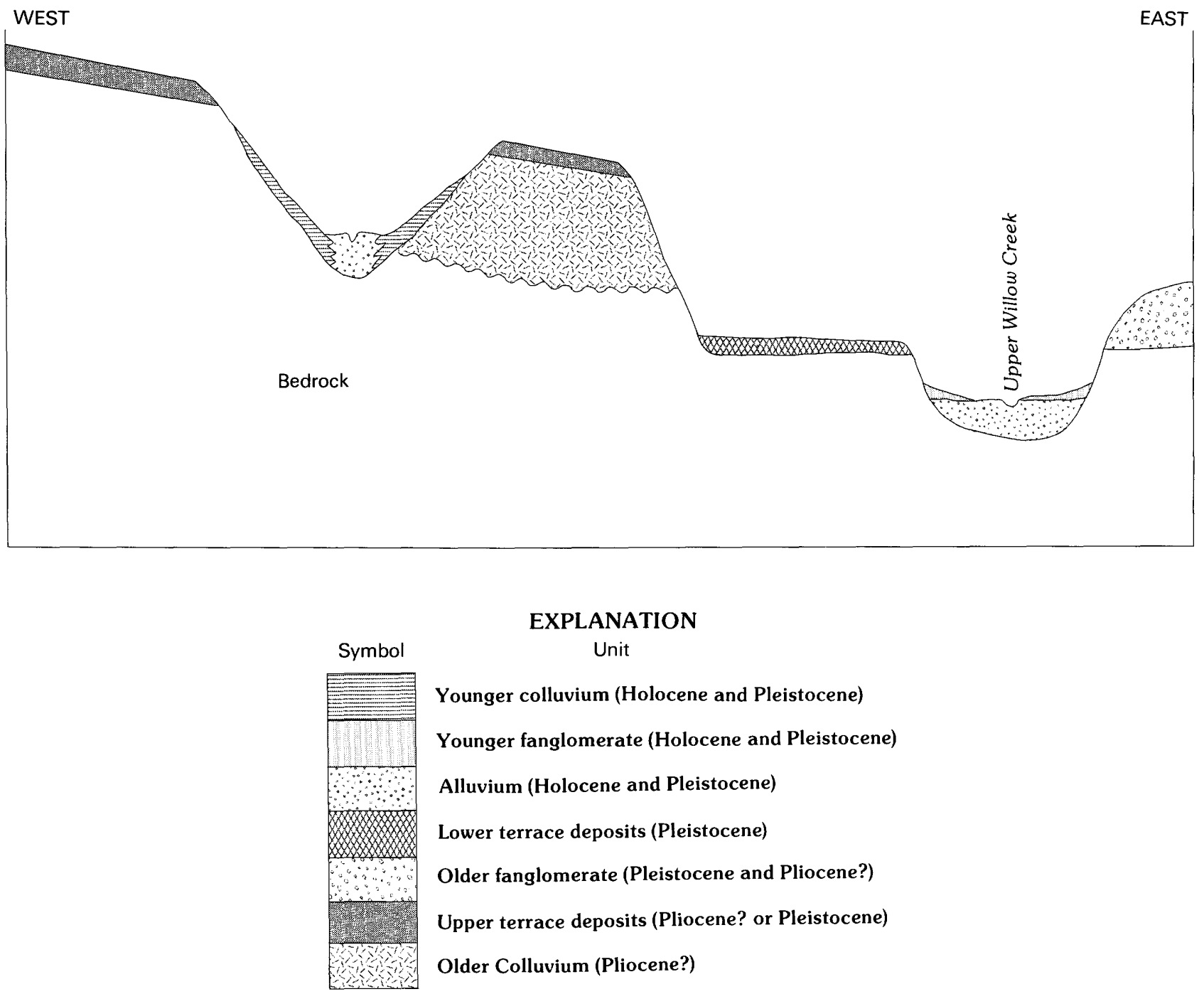

Figure 6. Schematic representation of stratigraphic relationships of Cenozoic sedimentary deposits in Miners Gulch area. Diagram shows a hypothetical cross section in which all Cenozoic units are present. Thickness of units is diagrammatic.

of the cobbles are white, pink, and red. The most common shape of the cobbles is oblate. Spherical cobbles are present but uncommon.

Material from a placer test trench south of Sawpit Gulch showed the following volumetric constitution: silt and clay (40-55 percent), sand (20-25 percent), pebbles (5-10 percent), cobbles (20-30 percent), and boulders (2-5 percent). Figure 7 shows a stratigraphic column of sediments exposed in the trench. Lithologies present along the crest of the hill in the NW $1 / 4 \mathrm{sec} .7, \mathrm{~T} .7 \mathrm{~N}$., R. 15 $\mathrm{W}$. , are listed in table 1.

The age of the upper terrace deposits cannot be directly ascertained because no datable materials have been found in them. The following evidence was used to tentatively assign a Pliocene(?) or early Pleistocene age:

(1) The deposits locally overlie Pliocene(?) basalt.

(2) The deposits have these weathering characteristics: (a) Well-developed soils-Soils generally contain red (5YR 5/6-10YR 6/6) Bt horizons at least 16-20 in. thick. This horizon has blocky ped structure, containing 1-in. peds. The soil in this argillic horizon is a sandy clay loam with high plasticity and moderate stickiness.

(b) One-inch-thick weathered rinds on rare andesite cobbles.

(c) Abundant shattered and split quartzite boulders on terrace surfaces (evidence of long-continued physical weathering).

(3) The once-level surface of the deposits has been tilted about 10 degrees to the east (fig. 6). This amount of tilting is consistent with attitudes of Pliocene deposits described by Reynolds (1979) in nearby valleys characterized by Pliocene-Pleistocene block faulting. 
Table 1. Lithologies and estimated frequency of 4-6 in. cobbles in upper terrace deposits

\begin{tabular}{|c|c|c|c|c|}
\hline Composition & Color & $\begin{array}{l}\text { Rounding } \\
\text { of cobbles }\end{array}$ & Grain size & $\begin{array}{l}\text { Percentage } \\
\text { of total }\end{array}$ \\
\hline $\begin{array}{l}\text { Feldspathic } \\
\text { quartzite }\end{array}$ & White & $\begin{array}{l}\text { Subrounded to } \\
\text { well rounded }\end{array}$ & Fine grained & $25-30$ \\
\hline $\begin{array}{r}\text { Feldspathic } \\
\text { sandstone }\end{array}$ & $\begin{array}{l}\text { Red, pink, } \\
\text { and purple }\end{array}$ & Subrounded & Medium grained & 20 \\
\hline Mudstone & $\begin{array}{l}\text { Purple to } \\
\text { gray }\end{array}$ & $\begin{array}{l}\text { Subangular to } \\
\text { well rounded }\end{array}$ & Fine grained & 15 \\
\hline Siltstone & Buff to black & $\begin{array}{l}\text { Subangular to } \\
\text { well rounded }\end{array}$ & Fine grained & $10-20$ \\
\hline Quartzite & White & We11 rounded & Coarse grained & $<10$ \\
\hline Granodiorite & White & Subrounded & Medium grained & $<10$ \\
\hline $\begin{array}{c}\text { Vesicular } \\
\text { basalt }\end{array}$ & Brown-black & Subrounded & Fine grained & $<10$ \\
\hline
\end{tabular}

Similar fluvial terrace deposits in western Montana, considered to be of Pliocene to early Quaternary age, were described by Pardee (1951), Alden, (1953), and Robinson, (1963).

Older fanglomerate.-Poorly sorted, angular gravel (map unit QTf) composed of Proterozoic sedimentary rocks cap the piedmont plain or bench on the east side of the Upper Willow Creek valley. The debris is composed mainly of pebble- to boulder-sized clasts in a fine-grained matrix. White quartzite of the Mount Shields Formation and red and green argillite of the Snowslip Formation comprise most of the clasts in deposits east of the study area.

Piedmont alluvial fans formed on the east side of the Upper Willow Creek valley during the late Pliocene or early Pliocene, probably in response to normal faulting. The eroded surface of the deposits still retains its smooth concave-upward profile and dips $3-10^{\circ}$ toward Upper Willow Creek (fig. 3). The fanglomerate is 50-100 ft thick along the lower parts of the bench, but its thickness may increase to $200-300 \mathrm{ft}$ toward the east because of the eastward tilting of the valley.

\section{Quaternary Deposits}

Lower terrace deposits.-Fluvial terrace deposits (map unit Qg) cover about $1 \mathrm{mi}^{2}$ between Sawpit Gulch and Scotchman Gulch. The deposits stand at a level 100-400 ft above Upper Willow Creek and tilt northeast. The deposits are probably less than $30 \mathrm{ft}$ thick.

Lithologies comprising this deposit are similar to those forming the upper terrace deposits. Feldspathic quartzites predominate, but vein quartz and granodiorite are locally abundant.

Age is indicated by position relative to the upper terrace and by weathering features. The lower terrace is hundreds of feet below the upper terrace deposits. The lower terrace shows less eastward tilting and weaker soil development than the upper terrace deposits. One stageI $\mathrm{K}$ horizon was seen in a roadcut in gravel along the Scotchman Gulch road in SW $1 / 4$ sec. 5, T. 7 N., R. 15 $\mathrm{W}$. It was below a 3-ft-thick $\mathrm{Bt}$ horizon with reddishbrown color. The lower terrace is tentatively given an early Pleistocene age.

Younger fanglomerate.-Alluvial fan deposits (map unit Qf) occupy the mouths of most streams tributary to Upper Willow Creek and the mouths of many sidestreams in the study area. The thickness of the fanglomerate deposits is variable, ranging from about $6 \mathrm{ft}$ to as much as $20 \mathrm{ft}$. The deposits are well stratified, containing well-sorted pebble layers alternating with beds of granitic sand or coarser gravel. Discontinuous bands of white volcanic clay (identified as dickite by X-ray analysis) are exposed in placer-mining cuts north of the mouth of Alder Gulch.

Secondary fan deposits, related to Pleistocene stream levels, were identified above the mouths of Alder, Niles, Homestake, and Miners Gulches. Some of these deposits were extensively placer mined. Because these secondary alluvial fans lie at levels above the present stream channels, the younger fanglomerate deposits are, in part, older than alluvium of late Pleistocene and Holocene age and thus may be as old as mid-Pleistocene. Alluvium.-Stream channels in the study area 


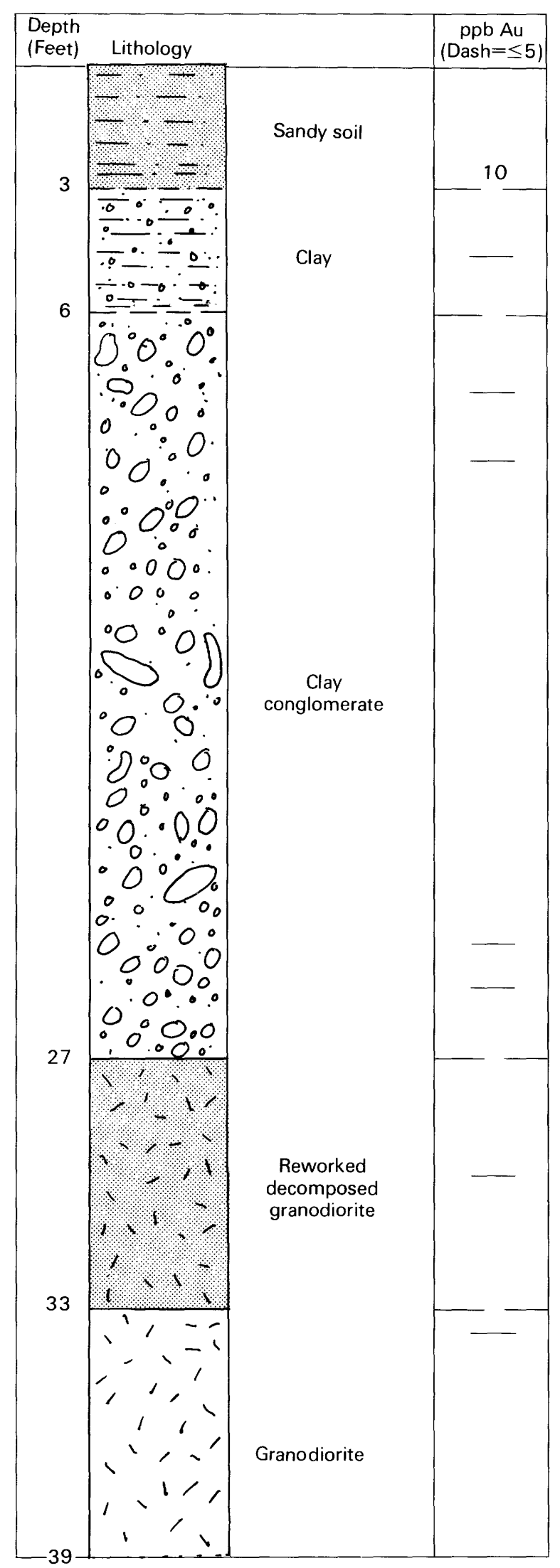

Figure 7. Stratigraphic column of upper terrace deposits south of Sawpit Gulch (data from backhoe excavation supplied by E. Miller, written commun., 1983). contain fluvial deposits (map unit Qal) which vary in composition and character from one stream to another and along the same stream valley. The alluvium is crudely layered, with stratified gravel-bar or channel-type cobble gravels forming lower parts, and packets of gray granodiorite sand alternating with thin cobble-gravel beds forming the top section (fig. 8). Volcanic ash and clay occur locally in the top section. Thickness, as seen in placer-mining workings and exploration trenches, is less than $25 \mathrm{ft}$.

Major lithologies in the alluvium in the study area (table 2) were identified during cobble counts in all streambeds. Cobbles of feldspathic quartzite were ubiquitous. Even streams such as Cowan and Miners Gulches, which flow through areas underlain totally by granodiorite, showed high percentages of feldspathic quartzite cobbles in alluvium. Well-rounded vein-quartz cobbles are locally abundant. These rock types are identical to

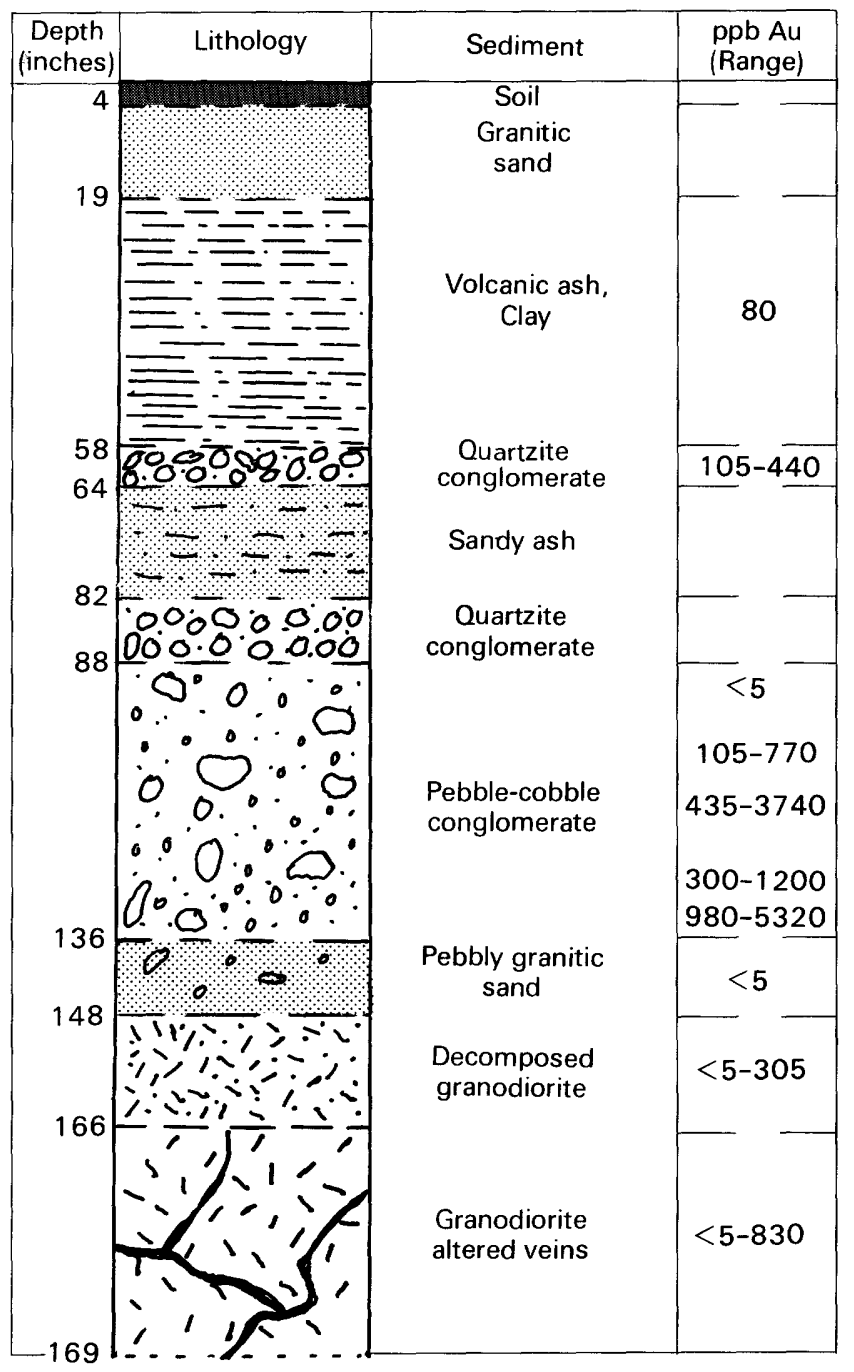

Figure 8. Stratigraphic column of Quaternary alluvium in Sawpit Gulch (data from backhoe excavation supplied by E. Miller, written commun., 1983). 
clasts abundant in the Pliocene or early Pleistocene upper terrace deposits. Most other rock types listed in table 2 , such as rhyolite, hornblende diorite, and barite are of more restricted distribution. These rocks occur only in stream channels that are directly downstream from their outcrops.

A placer mining excavation in Sawpit Gulch (in SE $1 / 4$ sec. 31, T. 8 N., R. 15 W.), made in 1980 by Everett and George Miller of Philipsburg, exposed the bones of at least one large bison. The remains consisted of an intact straight-horned skull, found in a humic soil zone $3.6 \mathrm{ft}$ below the surface, and a mandible, found in a granitic sand layer $8 \mathrm{ft}$ below the surface. Based on a comparative study, T. M. Bown, of the U.S. Geological Survey, identified the specimens as Bison occidentalis (written commun., 1982). Bison occidentalis is believed to have spread south from Alaska during the late Pleistocene. In the early Holocene it evolved into Bison bison of the Holocene (Geist, 1971; Guthrie, 1970). Wilson (1980) suggested a date of 5,000 years ago for the transition between these two bison forms on the northern plains.

The presence of Bison occidentalis remains in the sandy, upper layers of the alluvium tentatively dates the time of deposition of the sediment as early Holocene. This determination suggests that the underlying part of the alluvium, composed mostly of stratified gravel, is older than early Holocene, and is possibly of Wisconsin age. The vertical lithologic change in the alluvium may thus have been in response to climatic change following the Pleistocene, as the wet glacial climate changed to the drier climate of the altithermal.

Weathering effects seen in placer cuts support a Holocene age for the upper level of the alluvium. Soils are weakly developed, containing brown $\mathrm{C}$ horizons and little translocated clay. Boulders of granodiorite in the alluvium typically are highly decomposed.

Small stream terraces are locally well developed in gulches tributary to Upper Willow Creek (the following discussion of these terraces does not include terraces previously described as map units QTg or Qg):

Stream terraces, which were deposited after the present drainage net had been initiated, lie generally less than $100 \mathrm{ft}$ above the present streams. They mark minor stages of downcutting and lateral planation, possibly related either to downcutting episodes during the incision of the present drainage or to Pleistocene climatic changes. These terraces connect downstream with secondary alluvial-fan deposits lying above the mouths of gulches. Soils examined on the deposits are brown, less than $2 \mathrm{ft}$ thick, and show moderate development of soil horizons. A mid- to late Pleistocene age is thus tentatively assigned to these terraces.

Younger colluvium.-Colluvium (map unit Qc) is exposed in placer cuts on forested hillsides, most conspicuously between the lower parts of Miners and Homestake Gulches. These deposits are composed of loose granitic sand interbedded with quartzite pebble or cobble gravels. The colluvium typically fills bedrock depressions in granodiorite. The deposits grade into alluvium in stream channels. In the $\mathrm{S} 1 / 2 \mathrm{sec} .29, \mathrm{~T} .8 \mathrm{~N}$., R. $15 \mathrm{~W}$., colluvium was placer mined on granodioritefloored hillsides sloping toward the Upper Willow Creek flood plain from ridges capped by Pliocene or Pleistocene terrace deposits.

The deposits resemble stratified colluvial fills described by Dietrich and Dorn (1984) in coastal mountains of northern California, Oregon, and Washington. Dietrich and Dorn indicate that such deposits are also found in semi-arid climates. The age of the colluvium in the study area, as judged by weathering characteristics, may be late Pleistocene or early Holocene.

\section{Geologic History}

Elements of post-Cretaceous geologic history important to the development of mineral deposits in the study area are discussed here in chronological order.

During the early Tertiary, the Miners Gulch stock was intruded by a porphyritic granodiorite plug and its associated mineralization. Later, a series of dikes were emplaced, and these may have coincided with a period of hydrothermal veining. A period of erosion followed, and by the late Eocene the stock and its enclosing Belt Supergroup rocks were truncated by a major unconformity. Eocene volcanics, including andesitic flows and lesser rhyolite tuffs and flows, were erupted onto this erosional surface.

Oligocene and Miocene basin-fill deposits consisting largely of silt, clay, and volcanic ash accumulated in shallow subsiding basins of low relief that extended across the present site of the Upper Willow Creek valley and the John Long Mountains. Basin-range faulting began during middle Miocene time, when the outline of the present Upper Willow Creek valley was established. During the Pliocene, basalt was erupted onto the valley floor. The ancestral Upper Willow Creek, flowing north, deposited fluvial gravels of the upper terrace deposits on the basalt flows during the Pliocene or early Pleistocene. After a period of downcutting, the lower terrace was deposited-possibly during the early Pleistocene. Upper Willow Creek was then one of several north-flowing tributaries to the ancestral Clark Fork River. Also, during the Pliocene or early Pleistocene, older fanglomerate was deposited in alluvial fans which formed adjacent to the mountain front on the east side of the valley. The alluvial fans probably formed in response to basin-range normal faulting.

In the early Pleistocene, downcutting of streams 
Table 2. Lithologies in alluvium in study area based on visual estimations of clast lithologies and their characteristics seen in mine tailings of placer-mined stream channels

\begin{tabular}{|c|c|c|c|c|c|c|}
\hline Rock type ${ }^{1}$ & Source ${ }^{2}$ & $\begin{array}{l}\text { Size } \\
\text { (average) }\end{array}$ & Color & Rounding & Occurrence & Comments \\
\hline Granodiorite & Local & $>0.25 \mathrm{in}$ & $\begin{array}{l}\text { Gray, orange } \\
\text { (iron } \\
\text { stained) }\end{array}$ & Angular & A11 streams & $\begin{array}{l}\text { Sand commonly forms layers to } 6 \mathrm{ft} \\
\text { thick. Forms matrix in other } \\
\text { lithologies. }\end{array}$ \\
\hline $\begin{array}{r}\text { Feldspathic } \\
\text { quartzite }\end{array}$ & Foreign & $3-6$ in. & $\begin{array}{l}\text { Pinkish red, } \\
\text { gray, or black }\end{array}$ & $\begin{array}{l}\text { Subrounded to } \\
\text { well rounded }\end{array}$ & All streams & Derived from upper terrace deposits. \\
\hline Granodiorite & Local & 4-18 in. & Gray & $\begin{array}{l}\text { Subrounded to } \\
\text { well rounded }\end{array}$ & Al1 streams & $\begin{array}{l}\text { Spheroidally weathered boulders from } \\
\text { outcrops. }\end{array}$ \\
\hline Vein quartz & Local & $4-10$ in. & White, brown & $\begin{array}{l}\text { Angular to } \\
\text { subangular }\end{array}$ & All streams & $\begin{array}{l}\text { Contains euhedral quartz crystals coated } \\
\text { with yellow and red-brown fibrous or } \\
\text { boxwork limonite, botryoidal manganese } \\
\text { oxides, and tabular white barite } \\
\text { crystals. }\end{array}$ \\
\hline Vein quartz & Foreign & $2-8$ in. & Brown & Well rounded & Cowan Gulch & $\begin{array}{l}\text { Highly polished cobbles. Contains } \\
\text { chestnut-brown limonite. Derived from } \\
\text { upper terrace deposits. }\end{array}$ \\
\hline Quartzite & Local & $3-10$ in. & Gray & $\begin{array}{l}\text { Angular to } \\
\text { subrounded }\end{array}$ & Miners Gulch & $\begin{array}{l}\text { From nearby outcrops of Mount Shields } \\
\text { Formation. }\end{array}$ \\
\hline $\begin{array}{l}\text { Biotite- } \\
\quad \text { hornfels }\end{array}$ & Local & $3-10$ in. & Gray & $\begin{array}{l}\text { Angular to } \\
\text { subrounded }\end{array}$ & $\begin{array}{l}\text { Scotchman, } \\
\quad \text { Cowan Gulches }\end{array}$ & $\begin{array}{l}\text { From outcrops of metamorphosed Belt } \\
\text { units on Sandstone Ridge. }\end{array}$ \\
\hline Rhyolite & Local & $3-16$ in. & White & $\begin{array}{l}\text { Angular to } \\
\text { subangular }\end{array}$ & $\begin{array}{l}\text { Homestake, } \\
\quad \text { Miners Gulches }\end{array}$ & $\begin{array}{l}\text { From rhyolite dikes cutting Miners } \\
\text { Gulch stock. Prominent quartz } \\
\text { phenocrysts. }\end{array}$ \\
\hline $\begin{array}{l}\text { Hornblende } \\
\text { diorite }\end{array}$ & Local & $2-8$ in. & Dark gray & $\begin{array}{l}\text { Angular to } \\
\text { subrounded }\end{array}$ & $\begin{array}{l}\text { Cowan, Scotchman } \\
\text { Gulches }\end{array}$ & $\begin{array}{l}\text { From thin dikes cutting western part of } \\
\text { Miners Gulch stock. }\end{array}$ \\
\hline Barite & Local & $>.5$ in. & White & Angular & Sawpit Gulch & $\begin{array}{l}\text { From barite veins crossing Sawpit Gulch. } \\
\text { Forms lag deposits in stream. }\end{array}$ \\
\hline
\end{tabular}
Forms lag deposits in stream.

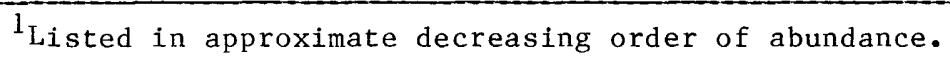

2"Local" indicates rock types derived from outcrops in local drainage basins. "Foreign" indicates rock types which probably

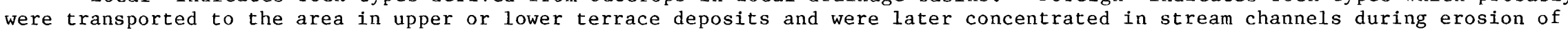
the terrace deposits. The source of the foreign rock types is undetermined. 
related to Rock Creek, possibly aided by tectonic tilting along normal faults on the east side of the Upper Willow Creek valley, caused Upper Willow Creek to reverse drainage direction and to flow south into Rock Creek. Following this capture and reversal, Upper Willow Creek and its side streams incised their channels, initiating a new drainage net. Streams cutting into the Miners Gulch stock were subsequently controlled by the strong orthogonal joint system in the stock. During the complex downcutting and refilling of sidestreams, the upper and lower terrace deposits were reworked and combined with local detritus to form alluvium and the younger alluvial-fan deposits.

During the Pleistocene glaciations, alluvium consisting of coarse-sized, well-stratified gravel was deposited by strong, deeply scouring streams. After the Wisconsin glaciation the competence of streams decreased and sandsized sediment began to dominate the stream deposits. Colluvial deposits, some of which contained placer gold, accumulated in bedrock depressions on granodiorite hillsides and intergraded with alluvium during the late Pleistocene.

Since the early Holocene, streams have remained at low levels of activity. Small alluvial fans have built up at the mouths of most streams.

\section{ECONOMIC GEOLOGY}

\section{History of Mining}

The Miners Gulch area has been the site of considerable mining and prospecting since the discovery of placer gold in Miners Gulch in 1867. Gold discoveries during the 1860's in western Montana usually resulted in gold rushes such as occurred at Gold Creek, Bannack, Alder Gulch, and Last Chance Gulch (Lyden, 1948), but it is doubtful that large groups of miners ever came to the Miners Gulch area.

Despite much local evidence of mining, few historical references and no mining claim records for this era could be found. Records may have been lost-for example, during the transfer of documents from the Deer Lodge County courthouse in Deer Lodge, Mont., to the Granite County courthouse in Philipsburg when Granite County was established in 1893-or the claims may never have been officially registered. Only about 25 miners were reportedly involved in the mining each year, and their work was seasonal because of summer water shortages and long winters. One water-rights claim is known, filed by Con Wiff, who worked in Miners Gulch.

Names of miners who worked in the area during the late 1800's are preserved in the names of placer-mined drainages such as Cowan, Coles, and Niles Gulches. Other gulches were named for cultural aspects of the area during this period. Scotchman Gulch referred to the nationality of its miners, whereas Sawpit Gulch took its name from a whipsawing operation that existed near its mouth for sawing boards to make sluiceboxes and other equipment. Homestake and Deadwood Gulches most likely were named during the 1870's after Homestake and Deadwood Gulches in the Black Hills of South Dakota. Alder Gulch drew its name from the alders that grow abundantly along its banks. The origin of the name for Baboon Gulch remains a mystery.

The 1870's and 1880's were apparently the most profitable period of placer mining. During this period, a summer population of approximately 25 miners worked several stretches of streams while living in scattered cabins (Hans Luthje, personal commun., 1982). Niles and Homestake are said to have contained the greatest concentrations of gold, and Alder and Scotchman contained the least (Hans Luthje, oral commun., 1982). Bill Carey, an early miner in Sawpit Gulch, reportedly claimed that an ounce of gold per man per day was produced there (Henry Hull, oral commun., 1982).

Because of summer water shortages, work commenced when spring runoff began and continued as long as sufficient water flowed. Local streams were often dry by early July. A local ditch network, estimated to be more than $100 \mathrm{mi}$ in length, was constructed to bring water from perennial streams to the drier gulches during summer months. A series of dams were built in order to manage the flow of water to workings.

The principal mining methods used were ground sluicing and booming (Griffith, 1960). During spring runoff, when water was abundant, ground sluicing was done by shoveling gravel directly into a sluice box positioned in the streambed. As summer approached and streamflow diminished, a variation of ground sluicing called "booming" was used. This method involved storing water behind earthen dams until the volume collected was sufficient to produce a rush of water when released. Rushing water, aided by shoveling miners, undercut the working face of the streambank and washed gravel through the sluice box. Hydraulic mining was attempted at about 1900 near the mouth of Miners Gulch. This method employed fabric hose with a hand-riveted steel nozzle to more efficiently direct water toward the gravel.

In addition to placer mining, several lode mines were operated near the mouth of Miners Gulch during the late 1800's. Two adits and a 3-stamp mill were operated by John Amesley during the 1890's in the NW $1 / 4$ sec. 32, T. 8 N., R. 15 W. (Hans Luthje, oral commun., 1982). The adits, now caved near their portals, appear to follow an east-trending vein in the Mount Shields quartzite and argillite. An arrastra, used to crush and liberate free-milling gold ore, was also used at this site. Small mines in Deadwood Gulch (SW 1/4 sec. 29, T. $8 \mathrm{~N}$., R. $15 \mathrm{~W}$.) may also have provided ore to Amesley's mill. Numerous prospect pits and shallow shafts (see pl. 1) were dug on oxidized vein outcrops throughout the area during the pre-1900 period. 
Mining activity began to decline around 1900. Placer mining was still conducted in some streams, such as Homestake Gulch, where Charlie Carpp Sr. worked between 1900 and 1910. Just north of the mouth of Alder Gulch, Vatis Page and L. W. Maxon hydraulic-mined the hillside as much as $100 \mathrm{ft}$ vertically above Alder Gulch between about 1926 and 1929. Lyden (1948) reported that 24.9 fine oz of placer gold were produced from four claims near Upper Willow Creek in 1933, 4 oz from two claims in 1935, and an unknown amount in 1919. The locations of these producing claims are unknown, but they are probably within the study area.

The only lode-mining activity known after 1900 was at the head of Deadwood Gulch, where John Jennings sunk two vertical shafts on a northeast-trending quartz and disseminated-sulfide vein sometime before 1930 (Hans Luthje, oral commun., 1982).

Little mining has occurred since the intermittent activity of the 1930's. Some small-scale placer mining was done during the 1960's or 1970's on Scotchman and Baboon Gulches, and recent activity (1982) centered on Homestake and Sawpit Gulches. In 1982, work at E. Miller's mine on Sawpit Gulch involved two small washing plants with a hopper capacity of less than $1 \mathrm{yd}^{3}$. The gravel was washed through a trommel and down a 24-ft sluice box employing riffles, expanded metal lath, and carpeting to catch the gold. This operation recovered 0.01-0.02 oz of gold per cubic yard of gravel.

Mineral exploration firms examined the area during the 1970's and 1980's. Placer exploration included digging several backhoe trenches on terrace remnants and in streambeds. Lode exploration was limited to bulldozer cuts on iron-stained zones, and to three drill holes, which probed a vein about $400 \mathrm{ft}$ southeast of the section corner in the NW $1 / 4$ sec. 32, T. 8 N., R. $15 \mathrm{~W}$.

\section{Production}

In lieu of records, a rough estimate of total early placer-gold production can be made using assumptions based on the average width and depth of workings, the total length of workings, and average gold content per cubic yard of gravel from E. Miller's 1982 placer operation in Sawpit Gulch.

Several problems are inherent in such an estimate. Variations in gold grade, mining techniques, fineness of gold, character of alluvium, and proximity to possible gold sources could all affect the production total. A conservative calculation is thus warranted.

The total length of placer-mined stream valleys shown on plate 1 is about $90,000 \mathrm{ft}$. An average cross section of workings is estimated to be about $15 \mathrm{ft}$ wide by $8 \mathrm{ft}$ deep (although the largest workings in the area are more than $200 \mathrm{ft}$ wide and $20 \mathrm{ft}$ deep). Allowance must be made for overburden, because the upper $2 \mathrm{ft}$ of alluvium commonly consists of barren silt, organic debris, and granodiorite boulders. Thus, using a semicircular cross-sectional area of $60 \mathrm{ft}^{2}$, the total volume of workings is about $5,400,000 \mathrm{ft}^{3}$, or $200,000 \mathrm{yd}^{3}$.

Recovery rates in Sawpit Gulch in 1982 were 0.01 to $0.02 \mathrm{oz}$ per cubic yard. At best, the more primitive extraction methods of the 19th century recovered possibly three-quarters of the gold. An estimate of $0.011 \mathrm{oz}$ per cubic yard for the earlier operations may be reasonable. The total production at this grade and the above estimated yardage would have been $2,200 \mathrm{oz}$ (valued at $\$ 45,500$ at $\$ 20.67$ per ounce). Table 3 compares this production estimate with those from other placer districts in the region.

\section{Gold Placer Deposits}

\section{Types of Placer Deposits}

Based on geomorphic origin in the study area, three types of gold placers were distinguished: alluvial, colluvial, and terrace. These types of placers correspond mainly to the alluvium, younger colluvium, and the upper and lower terrace deposits combined, respectively. The alluvial placers were the most widespread and productive of the three types. Colluvial placers were locally important producers. Terrace placers were not mined.

\section{Alluvial Placers}

Alluvial placers occur in stream channels and in related stream terraces and younger fanglomerate of Quaternary age. The deposits are restricted to active channels. The deposits are characterized by a upward-fining sequence ranging from cobble gravels to layers of fine granodiorite sand. The most frequently placer-mined alluvium contains large percentages of rounded quartzite clasts recycled from Pliocene-Pleistocene terrace alluvium.

\section{Colluvial Placers}

Colluvial placers fill bedrock depressions on hillsides and grade into alluvial placers; periodic emptying and refilling of the hillslope depressions (Dietrich and Dorn, 1984) may have controlled delivery of part of the gold supply to the active stream channels. Placers that occur on hillslopes have traditionally been termed "eluvial placers" or "residual mantle" (Bateman, 1950). However, rich gold lodes must be present in order to form significant eluvial placers, and the resulting eluvial deposits typically are directly on or adjacent to these lodes. In contrast, colluvial placers in the study area have 
Table 3. Production data for Miners Gulch area and neighboring placer districts

\begin{tabular}{|c|c|c|c|}
\hline District & Years & Production & Reference \\
\hline $\begin{array}{l}\text { Garnet } \\
\quad \text { (Bear Creek) }\end{array}$ & $1865-1959$ & $\begin{array}{c}5,500,000 \text { to } \\
7,500,000\end{array}$ & $\begin{array}{l}\text { Koschmann and Bergandahl, } \\
1968, \text { p. } 151 .\end{array}$ \\
\hline Pioneer & $1852-1942$ & $5,667,248$ & Pardee, 1951, p. 97. \\
\hline Ophir & $1865-1959$ & $3,600,000$ & $\begin{array}{l}\text { Koschmann and Bergandahl, } \\
1968, \text { p. } 168 .\end{array}$ \\
\hline Henderson & $1866-1959$ & $1,600,000$ & $\begin{array}{l}\text { Koschmann and Bergandahl, } \\
1968, \text { p. } 152 \text {. }\end{array}$ \\
\hline $\begin{array}{l}\text { Miners Gulch } \\
\text { area }\end{array}$ & $1867-1930^{\prime} \mathrm{s}$ & 45,500 & Present study. \\
\hline Welcome Creek & Pre-1911 & 30,000 & Rower, 1911, p. 877. \\
\hline
\end{tabular}

${ }^{1}$ In dollars at time of production.

resulted from downslope concentration of gold from two low-grade sources - the terrace placers and the lode veins in the granodiorite; the placer deposits have apparently been moved downslope a considerable distance.

Colluvium-filled depressions are probably the result of widening and deepening of joints in the granodiorite. Bedrock concavities, including joints, concentrate groundwater flow (Pierson, 1980), producing localized physical and chemical weathering. Solution of nonresistant bedrock minerals is known to be a major process by which rock material is removed from hillslopes (Rapp, 1960; Young, 1972), particularly in humid temperate climates (Saunders and Young, 1983). This process also may have played a part in developing the depressions, particularly during the Pleistocene when the climate was wetter. Solution also would have enriched gold deposits accumulating in the depressions because removal of soluble material causes concentration of heavy minerals, including gold. Removal of rock by transport of small mineral particles in suspension by ground water (suffosion) was recognized as an important placerforming mechanism by geologists in the U.S.S.R. (Shakhtyrov and Shumilov, 1981; Taysayev, 1983), and also probably operated in the Miners Gulch area during the Pleistocene when the climate was very wet.

Colluvial gold placers in the study area are described in detail by Loen in a separate chapter of this bulletin.

\section{Terrace Deposits}

Based on indirect geologic evidence, placers may be present within the upper and lower terrace deposits.
The most heavily mined deposits of the other placer types are, in part, reworkings of these terrace deposits. Old test pits were observed in some of the terraces; early miners apparently did test the gold content of the gravels. Factors that may have prevented the miners from working these deposits are:

(1) Grade-The terraces may have contained too low a concentration of gold. If sufficient gold had been found in the test pits, the miners would doubtless have attempted to work some of these deposits. An exploration test trench dug in upper terrace alluvium in the NE $1 / 4$ sec. 6, T. 7 N., R. 15 W. (fig. 7) contained negligible amounts of gold.

(2) Clay content-The terrace deposits contain thick, red, B horizons containing an estimated 40 percent of clay. The total depth of accumulation is not known, but in deposits of this age clay may be a significant component to depths as great as $4 \mathrm{ft}$. Such clay concentrations can cause significant goldbeneficiation problems.

(3) Availability of water-Several of the upper terrace deposits occupy locations unreachable by ditches because the terraces locally form the highest points on drainage divides.

\section{Descriptions of Mined Stream Drainages}

In the study area, mining was conducted in 10 different drainage basins and also on hillslopes near drainage divides. Workings ranged from narrow sluiced channels (fig. 9) to areas as wide as $500 \mathrm{ft}$, worked recently by modern earth-moving machinery. Plate 1 shows mines, 
prospects, and placer workings in the Miners Gulch area. Mining developments and the general character of deposits present in each drainage basin, from north to south, are described in the following brief summaries.

\section{Alder Gulch}

Wide expanses of Quaternary alluvium form the present flood plain of Alder Gulch. Areas as wide as 700 ft occur in the NE $1 / 4$ sec. 19 , T. 8 N., R. 15 W., although little of this ground was placer mined. Overall, more than 4 linear mi of Quaternary alluvium are exposed in the main stream channel. Less than 1 lin mi of this channel contains placer workings. The main channel rarely contains workings more than $20 \mathrm{ft}$ wide, or more than $8 \mathrm{ft}$ deep.

Extensive placer mining was conducted just north of the mouth of Alder Gulch, on a south-facing hillside that rises $250 \mathrm{ft}$ above the stream. Workings extend up this hill about 120 vertical feet in a series of cuts $15-100$ $\mathrm{ft}$ wide and as deep as $25 \mathrm{ft}$. These workings are apparently in a secondary alluvial fan, cut in granodiorite. The fan formed when Alder Gulch emptied into Upper Willow Creek at a much higher level than the streams occupy today. Alluvium is exposed at the base of the cuts, but uphill the workings expose colluvium, granodiorite bedrock, and a well-stratified gravel deposit.

\section{Niles Gulch}

Niles Gulch consists of a main channel and a north and a south fork. Alluvium in the gulch was mined repeatedly between the 1860 's and the 1880 's. Widths of placer workings in the main channel are generally $25 \mathrm{ft}$,

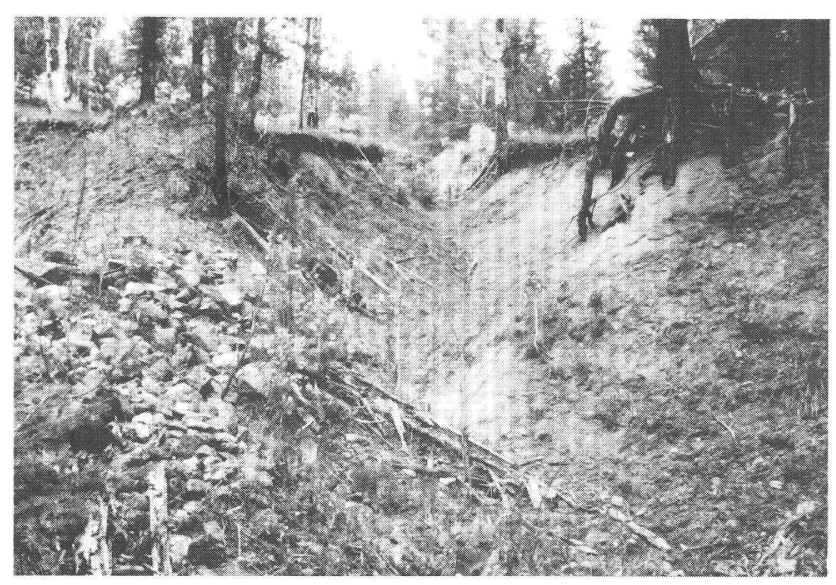

Figure 9. Placer workings north of mouth of Alder Gulch. Placer deposit is probably of colluvial origin. Bedrock is weathered and decomposed granodiorite. Tailings on left are composed predominantly of rounded quartzite cobbles and angular vein quartz. Workings are about 6-8 ft deep and 12-15 $\mathrm{ft}$ wide. and they are 10-20 ft deep. Workings in the north and south forks are rarely so substantial.

The major workings are in alluvial placer deposits, and reworked quartzite cobbles form much of the remaining tailings. Near the mouth of the gulch, younger fanglomerate deposits were mined by underground drifts.

\section{Homestake Gulch}

Homestake Gulch is the informal name for the eastward-flowing gulch south of Niles Gulch ( $\mathrm{N}^{1 / 2}$ secs. 29 and 30, T. 8. N., R. 15 W.). The gulch consists of one main channel approximately $1 \mathrm{mi}$ long. Placer workings are extensive along the entire length, ending below a dam near the head of the gulch. The placer deposits are in alluvium and colluvium. Workings in the main channel are commonly $50-100 \mathrm{ft}$ wide, but they are as wide as $600 \mathrm{ft}$ near the mouth of the gulch. The cuts are about $15 \mathrm{ft}$ deep.

\section{Unnamed Hillside Placer}

The single most intensely placer-mined area outside of main gulches is on a broad northeast-sloping hillside in the SW $1 / 4$ sec. 29, T. 8 N., R. $15 \mathrm{~W}$. The placer deposits present in this area are mainly of colluvial origin.

Because there were no streams on the hillside to supply water for placer mining, a 1.7-mi-long ditch was built to bring water from Miners Gulch. Water from this ditch was stored behind three dams along the hillside. From these reservoirs, miners brought water directly down the hillside at more than eight places by cutting long, straight channels. The channels were typically about $15 \mathrm{ft}$ wide and 5-12 ft deep; they connected farther downhill to form cuts hundreds of feet wide and 10-15 ft deep. The orientation of the cuts was partly controlled by bedrock ridges flanking the colluvium-filled depressions. The ridges are concordant with $\mathrm{N} .60^{\circ} \mathrm{E}$. and N. $30^{\circ} \mathrm{W}$. longitudinal joint sets in the granodiorite. Undisturbed ground between these placer channels ranges from about 10 to $30 \mathrm{ft}$ wide. The hillside surface, in the central area, slopes N. $50^{\circ} \mathrm{E}$. at about 6 degrees.

\section{Deadwood Gulch}

A series of placer workings in colluvial and alluvial deposits run southeast from the 150 -ft-long dam at the head of Deadwood Gulch. Placer-tailings piles contain much oxidized vein material.

Several veins cropping out along the gulch and on surrounding hillsides have been explored by underground mine workings. The largest underground workings are in the SW $1 / 4 \mathrm{sec} .29$, T. 8 N., R. $15 \mathrm{~W}$. This mine consists of three adit levels connected by two vertical shafts. The adits follow a steep east-west vein as much as 8 or 
10 in. wide within a brecciated zone in granodiorite. The length of exposed workings in this mine is about $450 \mathrm{ft}$. On the dumps are quartz-pyrite vein pieces, sericitically altered granodiorite containing disseminated limonite casts after pyrite, quartz vein breccia cemented with limonite, limonite masses, and gray quartz vein fragments. The mine was probably worked in the late 1880 's or 1890's. The same vein was exploited by two other adits $1,000 \mathrm{ft}$ east of the largest group of workings.

\section{Miners Gulch}

Lode workings are present near the mouth of Miners Gulch, where John Amesley operated a small mine and 3-stamp mill during the 1890's. The mine and mill lie adjacent to several acres of hydraulically mined pits and sluiced channels. Alluvial and colluvial placer deposits are present in or around Miners Gulch. Placermined channels are often $20-25 \mathrm{ft}$ wide and $10-15 \mathrm{ft}$ deep.

In addition to the work done in the main channel, tributaries to the lower stretch of Miners Gulch were placer mined. The largest of these is a southwest-flowing stream that meets Miners Gulch in the NE $1 / 4 \mathrm{sec} .31, \mathrm{~T}$. $8 \mathrm{~N}$., R. $15 \mathrm{~W}$. This drainage contains several thousand linear feet of placer-mined channel. On the east side of this drainage, a barite-rich vein has been explored by an adit (now caved), bulldozer cuts, and three drill holes. Two hundred feet of timber-supported, underground placer workings in alluvium and colluvium extended toward the vein outcrop from the main stream channel.

The 3-mi-long stretch of Miners Gulch above the junction with Cowan Gulch had no known significant placer mining or lode mining. The gravels were certainly tested because water was available and stream gradient is acceptably steep for sluicing; however, the gravels may have contained insufficient gold.

\section{Cowan Gulch}

Cowan Gulch contains placer workings as much as several hundred feet across and $25 \mathrm{ft}$ deep. Also present are numerous adits and pits which were dug to explore the extent and gold content of outcropping veins.

Placer deposits exposed in Cowan Gulch consist mainly of alluvial deposits of variable composition, all containing abundant grus. Cobbles of rounded quartzite, vein quartz, and gray hornblende-bearing igneous rock are conspicuous in tailings piles. Spheroidally weathered granodiorite boulders clog some stretches of stream, marked on the topographic map by steep sections of 100 vertical feet or more in $\mathbf{4 0 0}$ horizontal feet. No significant placer workings exist along these steep narrow chutes.

Abundant vein material occurs in the gravels along Cowan Gulch, especially near exposed veins. Where the 5,900 - $\mathrm{ft}$ contour crosses the gulch (pl. 1), on the north side of the stream, an 8 -in.-thick vein containing predominantly quartz, limonite, and barite was explored by an adit for at least $100 \mathrm{ft}$ along a S. $65^{\circ} \mathrm{W}$. bearing. Similar vein float covers several acres to the north and south of the adit. The locally derived vein material is recognized in placers by its angularity, but well-rounded and highly polished vein material derived from upper terrace deposits also occurs in alluvium along the gulch.

\section{Baboon Gulch}

This stream channel was placer mined for about $1.25 \mathrm{mi}$ of its length. Workings average about $10 \mathrm{ft}$ wide and $5 \mathrm{ft}$ deep. Alluvial placer deposits are composed chiefly of granodiorite debris. No quartzite cobbles derived from terrace gravels were seen. Subangular vein material is found in the stream deposits and littering hill slopes surrounding the stream. Many hours of panning along this stream yielded only a few gold grains.

\section{Coles Gulch}

Coles Gulch is similar to Baboon Gulch in the character of placer deposits and the extent of workings. One linear mile of workings in the main stream channel connects with larger workings in Cowan Gulch.

\section{Sawpit Gulch}

Sawpit Gulch is the site of some of the earliest and also the most recent placer mining in the area. An extensive system of workings dating back to the 1860's was expanded by bulldozer cuts and backhoe trenches during 1983.

About 1.7 lin mi of the main channel of the present stream has been mined along Sawpit Gulch. Workings are generally $20 \mathrm{ft}$ wide or more, and a section of channel may have several parallel placer cuts. Placer activities in 1983 disturbed areas of channel-fill approximately $250 \mathrm{ft}$ wide and $500 \mathrm{ft}$ long.

Gold-bearing deposits exposed in cuts and trenches are mainly of alluvial and colluvial placer types, and terrace gravels cap ridges adjacent to the stream. Vein fragments found in current placer workings are mostly angular, but minor amounts of well-rounded vein material are also present. Wire gold, tetrahedral gold crystals, and gold in a quartz matrix all occur in the new workings. Attempts at panning gold along this stream, particularly from thin gravel layers, were usually successful.

\section{Scotchman Gulch}

Small-scale placer mining, some of it conducted during the 1960's or 1970's, has occurred along several stretches of Scotchman Gulch. Well-stratified alluvial placer deposits are exposed in the cuts. 


\section{Vein Deposits and Altered Areas}

\section{Stages of Veining}

Mineralized veins are widespread throughout the study area, although they are mostly small, thin, and everywhere subeconomic at current metal prices. Thicknesses of the veins ranges from about $4 \mathrm{in}$. to $20 \mathrm{ft}$. The veins are exposed in roadcuts, prospect pits, and trenches throughout the area (plate 1). In the $\mathrm{N} 1 / 2 \mathrm{sec} .1, \mathrm{~T} .7 \mathrm{~N}$., R. $16 \mathrm{~W}$., gossan from veins is exposed in pits, shafts, and as abundant float. Little is known about the vertical extent of the veins in this area or about their metal content.

Veins are steepest in the eastern part of the stock, generally dipping more than $60^{\circ}$ and striking east-west. In the central and western parts of the stock, veins strike north-south and dip east at generally less than $30^{\circ}$ (fig. 10).

Studies of crosscutting relationships and vein symmetry revealed four episodes of veining in the study area. At most vein outcrops more than one stage is represented, but all four stages are rarely present at a single location. The episodes and their inferred relative ages are as follows: Stage I: Barren quartz

Stage II: Early sulfide

Stage III: Barite

Stage IV: Quartz-rich sulfide

The barren-quartz stage typically contains subhedral to euhedral quartz crystals ranging in size from 2 to $3 \mathrm{~mm}$ to about $10 \mathrm{~cm}$ in length and commonly exhibiting cockscomb structure. Veins of this stage are rare in the study area.

The early sulfide stage is preserved only as fibrous boxworks of iron and manganese oxides. Casts of striated cubic crystals are common. Examination of boxwork patterns, and the geochemistry and mineralogy of panned concentrates of pulverized vein samples suggest that pyrite was the major sulfide, although galena and sphalerite may have also been present. Veins of this stage are common and widespread throughout the study area.

The barite stage consists chiefly of coarse-grained white crystalline barite. It is typically barren of sulfides (except in an occurrence in a prospect in the NW $1 / 4 \mathrm{NW}$ $1 / 4$ sec. 32 , T. 8 N., R. 15 W., where barite is associated with tetrahedrite, chalcopyrite, and pyrite). Occurrences of this stage are widely scattered through the study area. Barite veins form the thickest known veins in the study area, reaching $20 \mathrm{ft}$ in thickness. Most known occurrences of veins of this stage are exposed in prospect pits or shafts, but barite has not been mined in the study area (a vein on a mining claim just south of the study area was described by Berg, 1982).

The quartz-rich sulfide stage is characterized by massive to euhedral quartz containing disseminated sulfides. Veins vary in thickness from $0.5 \mathrm{in}$. to $3 \mathrm{ft}$. Pyrite and chalcopyrite are the most abundant sulfides, followed by chalcocite, arsenopyrite, and stibnite. Veins of this stage are best represented along the eastern margin of the Miners Gulch stock in secs. 20, 29, 31, and 32, T. 8 N., R. $15 \mathrm{~W}$.

\section{Alteration}

Argillic, propyllitic, and sericitic alteration is found within the Miners Gulch stock and the porphyritic granodiorite plug that intrudes the stock. This alteration is associated with individual veins and zones of closely spaced veins and is generally limited to zones a few inches wide that border the veins. The most intense and pervasive alteration is coincident with the porphyritic granodiorite plug and extends into the surrounding granodiorite of the Miners Gulch stock. In other areas where veins are closely spaced (such as in the NE $1 / 4 \mathrm{sec}$. 35, T. 8 N., R. 16 W., SE $1 / 4$ sec. 36, T. 8 N., R. 16 W., and in the middle of sec. 25 , T. 8 N., R. 16 W.), alteration zones are wider and more intense.

Within the zone of pervasive alteration, centered on the porphyritic granodiorite plug in sec. $30, T .8 \mathrm{~N}$., R. $16 \mathrm{~W}$., strong propylitic to strong sericitic alteration is well developed and is associated with closely spaced quartz veinlets. Biotite and plagioclase are most notably altered and little evidence exists of the hornblende that probably was originally present in these rocks. The propylitic alteration suite of minerals usually includes chlorite, epidote, sericite, sphene, leucoxene, rutile, iron oxides, and in one case, topaz. Secondary phlogopite after biotite (phyllic alteration) was also noted in one thin section. Silicification in the form of quartz veinlets and secondary intergranular quartz is also common.

The quartz veinlets that cut the plug, its related dikes, and the surrounding granodiorite of the Miners Gulch stock commonly contain cubic pyrite casts as large as 1 in. and have fracture coatings of quartz, a green translucent mineral with acicular habit (possibly actinolite or tremolite), and a pink mineral (probably potassium feldspar). Locally, as in the SE $1 / 4 \mathrm{sec}$. 30 , the veinlets form a weak stockwork with as many as three different sets of fractures and (or) veinlets present.

Typically the dikes that cut the Miners Gulch stock are hydrothermally altered. The alteration varies from propylitic to sericitic with suites of alteration minerals similar to those described previously for the porphyritic granodiorite plug and granodiorite stock; the alteration is more intense close to the plug.

\section{Geochemistry}

\section{Sampling and laboratory procedure}

Field investigations involved collecting several kinds of samples from the study area. Thirty-seven panned 


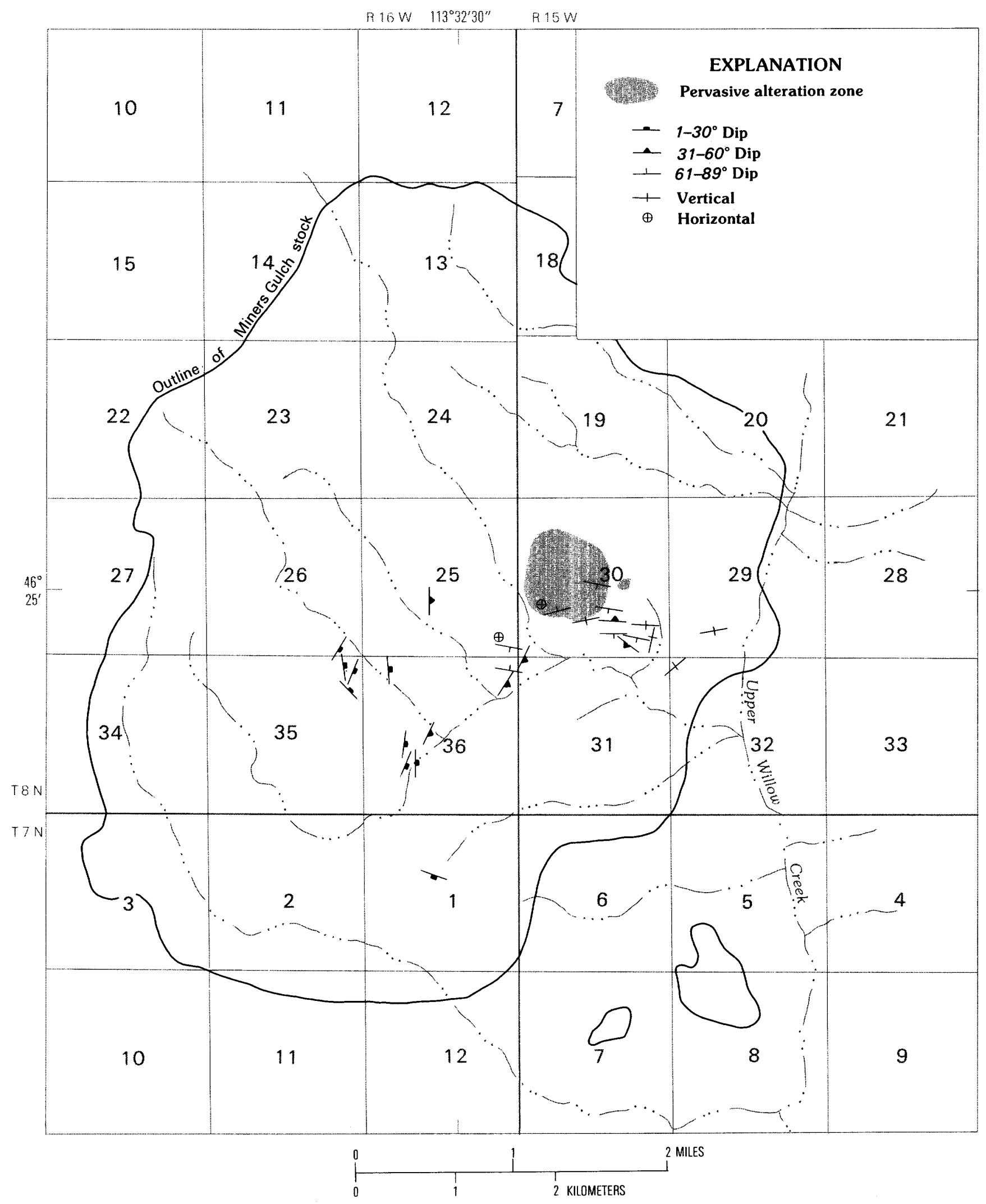

Figure 10. Map of vein attitudes in study area. Heavy line is outline of Miners Gulch stock. Measurements include veins of all four veining episodes. Other vein occurrences are known, but attitudes were not obtainable because of poor exposure. 
concentrates were collected from active streambeds for chemical analysis and to obtain samples of detrital gold. One hundred and thirty-three rock samples and 17 soil samples were collected for chemical analysis during mapping wherever altered or mineralized rocks were found. Ten bulk samples of veins were collected to obtain gold grains to compare with detrital gold grains. Sample site localities are shown on plate 1. Tables 4-12 lists results of chemical analyses for all types of samples.

Panned concentrates were collected within the study area during the summers of 1979 and 1982 . Seventeen of these were collected in 1979, during a regional geochemical study conducted by J. C. Antweiler as part of the U.S. Geological Survey's Conterminous United States Mineral Assessment Program (CUSMAP) for the Butte $1^{\circ} \times 2^{\circ}$ quadrangle. The samples were collected from 14 localities in seasonally active stream channels. All were panned down to approximately 10 grams of material, and from 11 of the 17 samples a $5 \mathrm{mg}$ split was submitted for semiquantitative spectrographic analysis (SQS). The remainder of each of the 11 samples was chemically analyzed for gold using an aqua-regia digestion and atomic absorption (AA) technique. As an experiment to enhance anomalies, the six extra samples were magnetically separated by the Frantz mineral separator operated at $\mathbf{0 . 6}$ and then 2.0 amperes. All fractions were then treated identically to the panned concentrates described above.

During 1982, an additional 20 panned concentrates were collected to acquire detrital gold for electronmicroprobe analysis. Thirteen localities were sampled in seasonally active stream beds, five in gravel hill cappings away from active drainages, and one in a roadcut exposing soil horizons. One final sample was a sluice concentrate from an active mining operation in Sawpit Gulch. Five to 20 pans of material (approximately 20-80 lbs) were concentrated at the 20 localities. An initial goal was to collect 50 visible particles of gold per locality, but this goal was reached in only one-third of the localities. An average of 25 particles per site was achieved. No attempt was made to estimate grade from these 20 samples. In the laboratory, samples were dried and the most magnetic fraction was separated by hand magnet. The remaining non-magnetic and weakly magnetic fraction was treated further using the Frantz mineral separator operated at 2.0 amperes to remove all magnetic material. This process resulted in three sample fractions: (1) a hand-magnetic fraction, (2) a fraction magnetic at 2.0 amperes, and (3) a non-magnetic fraction. Where present, detrital gold was found in the non-magnetic fraction. Gold was recovered by repeated careful panning of the sample fractions. Isolated gold grains were picked for photographing and then mounted and polished for electron microprobe analysis.

The hand-magnetic fraction and the 2.0-ampere fraction of each of these 20 samples were examined under a 45-power binocular microscope to determine mineralogy, and were checked for the presence of scheelite using ultra-violet luminescence. The following minerals, in approximate decreasing order of abundance, were identified: magnetite, quartz, barite, zircon, feldspar, sphene, amphibole, pyroxene, epidote, garnet, apatite, hematite, ilmenite, tourmaline, pyrite, chalcopyrite, cinnabar, orpiment and (or) realgar, arsenopyrite, stibnite, and scheelite or powellite.

Rock and soil samples were collected as small grab samples, approximately 1-2 lbs each, during the summers of 1980,1982, and 1983, and additionally as bulk samples, 30-50 lbs each, during the summer of 1982. A total of 133 rock and 17 soil samples was collected from 99 localities.

All grab samples were analyzed by SQS. One hundred twenty of the rock samples and three of the soil samples were analyzed for gold by AA analysis using an aqua-regia digestion. Fifty-three of the rock samples and three of the soil samples were also analyzed for arsenic, bismuth, cadmium, mercury, antimony, and zinc by AA, and 14 of the 17 soil samples were analyzed for fluorine by a specific ion electrode method.

Ten bulk samples of vein were collected from localities thought likely to contain visibly extractable gold. Five of these were collected from veins in which the early sulfide stage of veining was dominant, two from veins in which the quartz-sulfide stage was strongest and one from a vein in which the barite stage was dominant. The remaining two samples were of fluvially transported vein cobbles in Cowan and Sawpit Gulchs.

All bulk samples were reduced to minus-18 mesh using a jaw crusher, a roller crusher, and a vertical pulverizer. The result was 2-6 gal of material from each sample. Following crushing and pulverizing, two 1-pt splits were removed for SQS and AA analysis and for examination under ultraviolet light. The remainder of each sample was concentrated by panning. Gold was obtained from 5 of 10 samples and was identified but was not removable from one sample. Visible gold was hand picked for photographing and then mounted for electron microprobe analysis. Two gold specimens were lost during mounting and polishing. The remaining heavy concentrates were split once-one-half for SQS, the other half for mineralogic examination under a binocular microscope. Iron and manganese oxides, barite, and quartz were abundant, and the following ore minerals were also present: pyrite, chalcopyrite, tetrahedrite, bornite, arsenopyrite, stibnite, and scheelite or powellite.

\section{Correlation Analysis}

Correlations of elements in geochemical samples of veins and altered rock were calculated in order to identify strong element associations related to the veining stages. The data used for correlations are based on AA analyses for four elements (arsenic, mercury, antimony, 
Table 4. Semiquantitative spectrographic analyses for selected elements and atomic absorption analyses for gold in grab samples of altered rock or vein

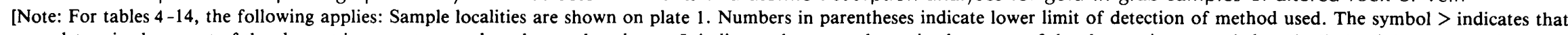

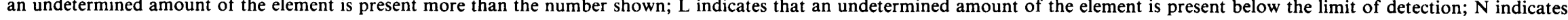

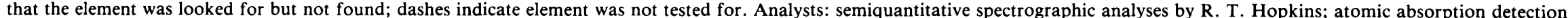
by K. A. Romine, J. Gray, and T. A. Roemer]

\begin{tabular}{|c|c|c|c|c|c|c|c|c|c|c|c|c|c|c|c|c|c|c|c|}
\hline \multirow[b]{2}{*}{ Sample } & \multicolumn{13}{|c|}{$(\mathrm{Ppm})$} & \multirow[b]{2}{*}{$\begin{array}{c}W \\
(50)\end{array}$} & \multicolumn{4}{|c|}{ (Percent) } & \multirow{2}{*}{ 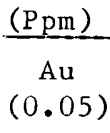 } \\
\hline & $\begin{array}{c}\mathrm{Mn} \\
(10)\end{array}$ & $\begin{array}{c}\mathrm{Ag} \\
(.5)\end{array}$ & $\begin{array}{c}\text { As } \\
(200)\end{array}$ & $\begin{array}{c}\text { B } \\
(10)\end{array}$ & $\begin{array}{c}\mathrm{Ba} \\
(20)\end{array}$ & $\begin{array}{r}\mathrm{Be} \\
(1)\end{array}$ & $\begin{array}{r}B i \\
(1)\end{array}$ & $\begin{array}{r}\mathrm{Cu} \\
(5)\end{array}$ & $\begin{array}{l}\text { Mo } \\
\text { (5) }\end{array}$ & $\begin{array}{r}\mathrm{Ni} \\
(5)\end{array}$ & $\begin{array}{l}\mathrm{Pb} \\
(10)\end{array}$ & $\begin{array}{c}\mathrm{Sb} \\
(100)\end{array}$ & $\begin{array}{c}\mathrm{Sr} \\
(100)\end{array}$ & & $\begin{array}{c}\mathrm{Fe} \\
(0.05)\end{array}$ & $\begin{array}{c}\mathrm{Mg} \\
(0.02)\end{array}$ & $\begin{array}{c}\mathrm{Ca} \\
(0.05)\end{array}$ & $\begin{array}{c}\mathrm{Ti} \\
(0.002)\end{array}$ & \\
\hline B2024A & 5000 & $\mathrm{~N}$ & $\mathrm{~N}$ & 700 & 1500 & 2 & $N$ & 5 & 10 & 20 & 10 & $\mathrm{~N}$ & $\mathrm{~N}$ & $\mathrm{~N}$ & 15 & .3 & .1 & .15 & .05 \\
\hline B2028A & 5000 & $\mathrm{~N}$ & $\mathrm{~N}$ & 700 & 1500 & 2 & $\mathrm{~N}$ & L & 7 & 20 & $\mathrm{~N}$ & $\mathrm{~N}$ & $\mathrm{~N}$ & $\mathrm{~N}$ & 15 & .2 & .05 & .15 & .05 \\
\hline B2029A & 5000 & 2 & $\mathrm{~N}$ & 500 & 2000 & 1.5 & 20 & 200 & 50 & 20 & 30 & $\mathrm{~L}$ & $\mathrm{~N}$ & $\mathrm{~N}$ & $>20$ & .15 & .1 & .05 & .05 \\
\hline B2030A & 1000 & $\mathrm{~N}$ & $\mathrm{~N}$ & $\mathrm{~N}$ & $>5000$ & $\mathrm{~N}$ & $\mathrm{~N}$ & 7 & 10 & 30 & $\mathrm{~N}$ & $\mathrm{~N}$ & 100 & $\mathrm{~N}$ & $>20$ & .05 & $\mathrm{~L}$ & .002 & $\mathrm{~L}$ \\
\hline B2038A & 2000 & $\mathrm{~N}$ & $\mathrm{~N}$ & $\mathrm{~N}$ & 1000 & $\mathrm{~N}$ & $\mathrm{~N}$ & 20 & $\mathrm{~N}$ & 30 & $\mathrm{~N}$ & $\mathrm{~N}$ & $\mathrm{~N}$ & $\mathrm{~N}$ & $>20$ & .07 & .05 & $\mathrm{~L}$ & L \\
\hline B2039A & 2000 & $\mathrm{~N}$ & $\mathrm{~N}$ & $\mathrm{~N}$ & 200 & $\mathrm{~N}$ & $\mathrm{~N}$ & $\mathrm{~L}$ & $\mathrm{~N}$ & 20 & $\mathrm{~N}$ & $\mathrm{~N}$ & $\mathrm{~N}$ & $\mathrm{~N}$ & 20 & .07 & $\mathrm{~L}$ & .003 & $\mathrm{~L}$ \\
\hline B2040A & 150 & .7 & $\mathrm{~N}$ & 700 & 150 & 2 & $\mathrm{~N}$ & 5 & $\mathrm{~N}$ & 7 & L & $\mathrm{N}$ & $\mathrm{N}$ & $\mathrm{N}$ & 2 & .3 & .1 & .5 & $\mathrm{~L}$ \\
\hline B2046 ${ }^{1}$ & 1000 & $\mathrm{~N}$ & $\mathrm{~N}$ & $\mathrm{~N}$ & 150 & $\mathrm{~L}$ & $\mathrm{~N}$ & 20 & 10 & 30 & 20 & $\mathrm{~N}$ & $\mathrm{~N}$ & 70 & 20 & .05 & $\mathrm{~L}$ & .005 & $\mathrm{~N}$ \\
\hline B2048A & 5000 & $\mathrm{~N}$ & $\mathrm{~N}$ & $\mathrm{~N}$ & 1000 & $\mathrm{~N}$ & $N$ & 7 & $\mathrm{~N}$ & 50 & $\mathrm{~N}$ & $\mathrm{~N}$ & $\mathrm{~N}$ & $\mathrm{~N}$ & $>20$ & .3 & $\mathrm{~L}$ & .015 & $\mathrm{~L}$ \\
\hline B2049A & 5000 & $\mathrm{~N}$ & $\mathrm{~N}$ & $\mathrm{~N}$ & 700 & $\mathrm{~N}$ & $\mathrm{~N}$ & 20 & $\mathrm{~N}$ & 30 & $\mathrm{~N}$ & $\mathrm{~N}$ & $\mathrm{~N}$ & $\mathrm{~N}$ & $>20$ & .2 & $\mathrm{~L}$ & .003 & .05 \\
\hline B2050A & 5000 & $\mathrm{~N}$ & $\mathrm{~N}$ & $\mathrm{~N}$ & 700 & $\mathrm{~N}$ & $\mathrm{~N}$ & 50 & $\mathrm{~N}$ & 50 & $\mathrm{~N}$ & $\mathrm{~N}$ & $\mathrm{~N}$ & $\mathrm{~N}$ & $>20$ & .2 & $\mathrm{~L}$ & $\mathrm{~L}$ & .05 \\
\hline $\mathrm{B} 2051 \mathrm{~A}$ & 3000 & $\mathrm{~N}$ & $\mathrm{~N}$ & $\mathrm{~N}$ & $>5000$ & $\mathrm{~N}$ & $\mathrm{~N}$ & 15 & $\mathrm{~N}$ & 30 & $\mathrm{~L}$ & $\mathrm{~N}$ & 1500 & $\mathrm{~N}$ & 15 & .07 & $\mathrm{~L}$ & $\mathrm{~L}$ & $\mathrm{~L}$ \\
\hline B2054A & 3000 & $\mathrm{~N}$ & $\mathrm{~N}$ & $\mathrm{~N}$ & 5000 & 1 & $\mathrm{~N}$ & 20 & $\mathrm{~N}$ & 50 & 15 & $\mathrm{~N}$ & $\mathrm{~N}$ & $\mathrm{~L}$ & $>20$ & .07 & $\mathrm{~L}$ & .005 & $\mathrm{~L}$ \\
\hline B2056B & 500 & $\mathrm{~N}$ & $\mathrm{~N}$ & 70 & $>5000$ & $\mathrm{~N}$ & $\mathrm{~N}$ & $\mathrm{~L}$ & $\mathrm{~N}$ & 5 & 20 & $\mathrm{~N}$ & 1000 & $\mathrm{~N}$ & 5 & 1 & 7 & .5 & $\mathrm{~L}$ \\
\hline B2058A & 700 & $\mathrm{~N}$ & $\mathrm{~N}$ & $\mathrm{~N}$ & 150 & $\mathrm{~N}$ & $\mathrm{~N}$ & 20 & $\mathrm{~N}$ & 30 & $\mathrm{~N}$ & $\mathrm{~N}$ & $\mathrm{~N}$ & $\mathrm{~N}$ & 20 & .02 & $\mathrm{~L}$ & $\mathrm{~L}$ & $\mathrm{~L}$ \\
\hline B2063 & 1500 & $\mathrm{~N}$ & $\mathrm{~N}$ & 200 & 500 & 1.5 & $\mathrm{~N}$ & 70 & $\mathrm{~N}$ & 20 & $\mathrm{~L}$ & $\mathrm{~N}$ & $\mathrm{~N}$ & $\mathrm{~N}$ & 15 & .15 & $\mathrm{~L}$ & .15 & -- \\
\hline B2064 & 300 & $\mathrm{~L}$ & 700 & 70 & 200 & 1.5 & $\mathrm{~N}$ & 200 & 70 & 30 & 10 & 100 & $\mathrm{~N}$ & $\mathrm{~N}$ & 20 & .05 & $\mathrm{~L}$ & .05 & -- \\
\hline $\mathrm{B} 2131 \mathrm{~A}$ & 3000 & $\mathrm{~N}$ & $\mathrm{~N}$ & $\mathrm{~N}$ & 700 & $\mathrm{~L}$ & $\mathrm{~N}$ & 10 & 10 & 20 & $\mathrm{~N}$ & $\mathrm{~N}$ & $\mathrm{~N}$ & $\mathrm{~N}$ & $>20$ & .02 & $\mathrm{~L}$ & .005 & -- \\
\hline B2 $131 \mathrm{~B}$ & 300 & $\mathrm{~N}$ & $\mathrm{~N}$ & 70 & 300 & 1.5 & $\mathrm{~N}$ & L & $\mathrm{N}$ & 7 & 10 & $\mathrm{~N}$ & 100 & $\mathrm{~N}$ & 1 & .3 & .5 & .2 & -- \\
\hline B2133 & 700 & 5 & $\mathrm{~N}$ & 20 & 5000 & $\mathrm{~L}$ & 20 & 500 & $\mathrm{~N}$ & 7 & 50 & $\mathrm{~N}$ & L & $\mathrm{L}$ & 10 & .02 & $\mathrm{~L}$ & .01 & -- \\
\hline B2 134 & 1000 & $\mathrm{~N}$ & $\mathrm{~N}$ & $\mathrm{~N}$ & 150 & $\mathrm{~N}$ & $\mathrm{~N}$ & 50 & $\mathrm{~N}$ & 10 & 10 & $\mathrm{~N}$ & $\mathrm{~N}$ & $\mathrm{~N}$ & 20 & $\mathrm{~L}$ & $\mathrm{~L}$ & $\mathrm{~L}$ & -- \\
\hline B2135 2 & 1000 & $\mathrm{~N}$ & $\mathrm{~N}$ & 100 & 300 & 2 & $\mathrm{~N}$ & 15 & 7 & 15 & 30 & $\mathrm{~N}$ & N & $\mathrm{N}$ & 3 & .15 & .07 & .15 & $\mathrm{~N}$ \\
\hline B2 140 & 200 & $\mathrm{~N}$ & $\mathrm{~N}$ & $\mathrm{~N}$ & $>5000$ & $\mathrm{~N}$ & $\mathrm{~N}$ & $\mathrm{~L}$ & 50 & 10 & 10 & $\mathrm{~N}$ & 1000 & $\mathrm{~N}$ & 15 & $\mathrm{~L}$ & L & $\mathrm{N}$ & -- \\
\hline B2141 & 50 & $\mathrm{~N}$ & $\mathrm{~N}$ & 100 & 1000 & 1.5 & $\mathrm{~N}$ & $\mathrm{~L}$ & $\mathrm{~N}$ & 15 & $\mathrm{~L}$ & $\mathrm{~N}$ & L & $\mathrm{N}$ & 3 & .07 & .05 & .1 & -- \\
\hline B2 142 & 200 & $\mathrm{~N}$ & $\mathrm{~N}$ & 20 & 1000 & $\mathrm{~L}$ & $\mathrm{~N}$ & 15 & 30 & 7 & $\mathrm{~L}$ & $\mathrm{~N}$ & $\mathrm{~N}$ & $\mathrm{~L}$ & 15 & $\mathrm{~L}$ & $\mathrm{~L}$ & .007 & -- \\
\hline B2 $144^{1}$ & 700 & $\mathrm{~N}$ & $\mathrm{~N}$ & $\mathrm{~N}$ & $>5000$ & $\mathrm{~L}$ & $\mathrm{~N}$ & 15 & $\mathrm{~N}$ & 30 & 20 & $\mathrm{~N}$ & 300 & 50 & 7 & .07 & .1 & .015 & .95 \\
\hline B3 $002 \mathrm{~A}$ & 70 & .7 & $\mathrm{~N}$ & $\mathrm{~N}$ & 200 & 2 & $\mathrm{~N}$ & 15 & 70 & 30 & 30 & $\mathrm{~N}$ & $\mathrm{~N}$ & $\mathrm{~N}$ & 15 & .05 & .07 & .05 & .05 \\
\hline $\mathrm{B} 3002 \mathrm{~B}$ & 20 & $\mathrm{~N}$ & $\mathrm{~N}$ & 30 & 150 & 5 & $\mathrm{~N}$ & 10 & 30 & 30 & 15 & $\mathrm{~N}$ & $\mathrm{~N}$ & $\mathrm{~L}$ & 15 & .15 & .1 & .07 & $\mathrm{~L}$ \\
\hline B3003B & 200 & 1 & $\mathrm{~N}$ & 30 & 500 & 1.5 & $\mathrm{~N}$ & 15 & 20 & 15 & 10 & $\mathrm{~N}$ & $\mathrm{~N}$ & $\mathrm{~N}$ & 5 & .07 & $\mathrm{~L}$ & .01 & $\mathrm{~N}$ \\
\hline B3004A & 500 & $\mathrm{~N}$ & $\mathrm{~N}$ & 20 & $>5000$ & 2 & $\mathrm{~N}$ & 5 & 10 & 10 & 10 & $\mathrm{~N}$ & 500 & $\mathrm{~N}$ & 5 & .07 & .1 & .15 & $\mathrm{~N}$ \\
\hline
\end{tabular}




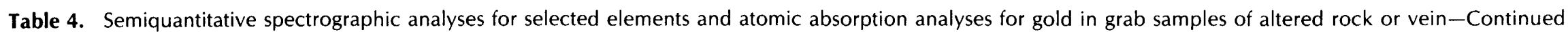

\begin{tabular}{|c|c|c|c|c|c|c|c|c|c|c|c|c|c|c|c|c|c|c|c|}
\hline \multirow[b]{2}{*}{ Sample } & \multicolumn{13}{|c|}{$(\mathrm{Ppm})$} & \multirow[b]{2}{*}{$\begin{array}{c}W \\
(50)\end{array}$} & \multicolumn{4}{|c|}{ (Percent) } & \multirow{2}{*}{$\frac{(\mathrm{Ppm})}{\mathrm{Au}}\left(\begin{array}{c}\mathrm{Au} \\
(0.05)\end{array}\right.$} \\
\hline & $\begin{array}{l}\text { Mn } \\
(10)\end{array}$ & $\begin{array}{c}\mathrm{Ag} \\
(.5)\end{array}$ & $\begin{array}{c}\text { As } \\
(200)\end{array}$ & $\begin{array}{c}\text { B } \\
(10)\end{array}$ & $\begin{array}{c}\mathrm{Ba} \\
(20)\end{array}$ & $\begin{array}{r}\mathrm{Be} \\
(1)\end{array}$ & $\begin{array}{r}\mathrm{Bi} \\
(1)\end{array}$ & $\begin{array}{l}\mathrm{Cu} \\
(5)\end{array}$ & $\begin{array}{r}\text { Mo } \\
(5)\end{array}$ & $\begin{array}{r}\mathrm{Ni} \\
(5)\end{array}$ & $\begin{array}{c}\mathrm{Pb} \\
(10)\end{array}$ & $\begin{array}{c}\mathrm{Sb} \\
(100)\end{array}$ & $\begin{array}{c}\mathrm{Sr} \\
(100)\end{array}$ & & $\begin{array}{c}\mathrm{Fe} \\
(0.05)\end{array}$ & $\begin{array}{c}\mathrm{Mg} \\
(0.02)\end{array}$ & $\begin{array}{c}\mathrm{Ca} \\
(0.05)\end{array}$ & $\begin{array}{c}\mathrm{Ti} \\
(0.002)\end{array}$ & \\
\hline B3005A & 150 & 2 & $\mathrm{~N}$ & 50 & 2000 & 2 & $\mathrm{~N}$ & 15 & 10 & $\mathrm{~L}$ & 10 & $\mathrm{~N}$ & 200 & $\mathrm{~N}$ & 1 & .15 & .1 & .3 & $\mathrm{~L}$ \\
\hline B3006A & 150 & $\mathrm{~N}$ & $\mathrm{~N}$ & 50 & 300 & 2 & $\mathrm{~N}$ & 10 & $\mathrm{~N}$ & 7 & 10 & $\mathrm{~N}$ & 150 & $\mathrm{~N}$ & 1 & .7 & .3 & .2 & $\mathrm{~N}$ \\
\hline B3007A & 70 & $\mathrm{~N}$ & $\mathrm{~N}$ & L & 500 & $\mathrm{~L}$ & $\mathrm{~N}$ & 5 & $\mathrm{~N}$ & $\mathrm{~L}$ & 15 & $\mathrm{~N}$ & 500 & $\mathrm{~N}$ & .2 & .15 & .5 & .07 & $\mathrm{~N}$ \\
\hline B3008A & 150 & $\mathrm{~N}$ & $\mathrm{~N}$ & 100 & 700 & 2 & $\mathbf{N}$ & $\mathrm{L}$ & $\mathrm{N}$ & 10 & 20 & $\mathrm{~N}$ & 150 & $\mathrm{~N}$ & 1 & .2 & .15 & .1 & $\mathrm{~N}$ \\
\hline B3009A & 1000 & $\mathrm{~N}$ & $\mathrm{~N}$ & 70 & 500 & 2 & $\mathrm{~N}$ & 5 & 7 & 20 & 15 & $\mathrm{~N}$ & $\mathrm{~N}$ & $\mathrm{~N}$ & 10 & .05 & .05 & .03 & .05 \\
\hline B3010A & 200 & $\mathrm{~N}$ & $\mathrm{~N}$ & 50 & 200 & 1.5 & $\mathrm{~N}$ & $\mathrm{~L}$ & $\mathrm{~N}$ & 7 & $\mathrm{~L}$ & $\mathrm{~N}$ & 150 & $\mathrm{~N}$ & .5 & .15 & .15 & .2 & $\mathrm{~N}$ \\
\hline B3010C & 300 & $\mathrm{~N}$ & $\mathrm{~N}$ & 10 & $>5000$ & 1 & $\mathrm{~N}$ & $\mathrm{~L}$ & $\mathrm{~L}$ & 10 & $\mathrm{~L}$ & $\mathrm{~N}$ & 1000 & $\mathrm{~N}$ & 2 & .05 & .07 & .07 & $\mathrm{~N}$ \\
\hline B3011A & 500 & $\mathrm{~N}$ & $\mathrm{~N}$ & 30 & $>5000$ & $\mathrm{~L}$ & $\mathrm{~N}$ & $\mathrm{~L}$ & $\mathrm{~N}$ & 5 & $\mathrm{~L}$ & $\mathrm{~N}$ & $>5000$ & $\mathrm{~N}$ & 1 & .02 & $\mathrm{~L}$ & .05 & .05 \\
\hline B3012A & 100 & $\mathrm{~N}$ & $\mathrm{~N}$ & 70 & 3000 & 1.5 & $\mathrm{~N}$ & $\mathrm{~L}$ & $\mathrm{~N}$ & 7 & $\mathrm{~L}$ & $\mathrm{~N}$ & 100 & $\mathrm{~N}$ & .7 & .1 & .15 & .3 & $\mathrm{~N}$ \\
\hline B3014A & 150 & $\mathrm{~N}$ & $N$ & 10 & $>5000$ & 1.5 & 30 & 5 & 10 & 15 & 10 & $\mathrm{~N}$ & 1000 & $\mathrm{~N}$ & 5 & .1 & .2 & .3 & $\mathrm{~N}$ \\
\hline B3015A & 1000 & $\mathrm{~N}$ & $\mathrm{~N}$ & $\mathrm{~N}$ & 500 & $\mathrm{~L}$ & $\mathrm{~N}$ & 20 & 20 & 70 & 10 & $\mathrm{~N}$ & $\mathrm{~N}$ & 100 & 20 & .07 & $\mathrm{~L}$ & .005 & $\mathrm{~N}$ \\
\hline B3015B & 2000 & $\mathrm{~N}$ & $\mathrm{~N}$ & $\mathrm{~N}$ & 500 & $\mathrm{~N}$ & $\mathrm{~N}$ & 15 & $\mathrm{~N}$ & 70 & 10 & $\mathrm{~N}$ & $\mathrm{~N}$ & $\mathrm{~N}$ & 20 & .1 & $\mathrm{~L}$ & .002 & .05 \\
\hline $\mathrm{B} 3016 \mathrm{~A}$ & 1000 & 3 & $\mathrm{~N}$ & $\mathrm{~L}$ & $>5000$ & $\mathrm{~L}$ & $\mathrm{~N}$ & 20 & $\mathrm{~N}$ & 15 & 20 & $\mathrm{~L}$ & 1000 & $\mathrm{~N}$ & 5 & $\mathrm{~L}$ & $\mathrm{~L}$ & .007 & .05 \\
\hline B3016B & 3000 & $\mathrm{~N}$ & $\mathrm{~N}$ & $\mathrm{~N}$ & 700 & L & $\mathrm{N}$ & 5 & $\mathrm{~N}$ & 70 & 15 & $\mathrm{~N}$ & $\mathrm{~N}$ & $\mathrm{~N}$ & 20 & .07 & .05 & .03 & $\mathrm{~L}$ \\
\hline B3017A & 5000 & $N$ & $\mathrm{~N}$ & $\mathrm{~N}$ & $>5000$ & $\mathrm{~N}$ & $\mathrm{~N}$ & 20 & $\mathrm{~N}$ & 50 & 20 & $\mathrm{~N}$ & 500 & $\mathrm{~N}$ & 20 & $\bullet 1$ & $\mathrm{~L}$ & .003 & .20 \\
\hline B3019A & 5000 & 10 & 200 & 15 & 500 & $L$ & $\mathrm{~N}$ & 1500 & $N$ & 15 & 20 & 150 & $\mathrm{~N}$ & $\mathrm{~N}$ & 7 & .07 & $\mathrm{~L}$ & .03 & .15 \\
\hline B3020 & 5000 & $\mathrm{~N}$ & $\mathrm{~N}$ & 70 & 700 & $\mathrm{~L}$ & $\mathrm{~N}$ & 20 & $\mathrm{~N}$ & 70 & 10 & $\mathrm{~N}$ & $\mathrm{~N}$ & $\mathrm{~N}$ & 20 & .15 & .07 & .1 & .30 \\
\hline B302 1A & 5000 & $\mathrm{~N}$ & $\mathrm{~N}$ & $\mathrm{~N}$ & 500 & $\mathrm{~L}$ & $\mathrm{~N}$ & 30 & $\mathrm{~N}$ & 70 & 10 & $\mathrm{~N}$ & $\mathrm{~N}$ & $\mathrm{~N}$ & 20 & .1 & $\mathrm{~L}$ & .03 & .15 \\
\hline B3022A & $>5000$ & $\mathrm{~N}$ & $\mathrm{~N}$ & $\mathrm{~N}$ & 1500 & $\mathrm{~L}$ & $\mathrm{~N}$ & 30 & $\mathrm{~N}$ & 70 & 50 & $\mathrm{~N}$ & $\mathrm{~N}$ & $\mathrm{~N}$ & 20 & .3 & .2 & .1 & $\mathrm{~L}$ \\
\hline B3023A & 3000 & 1 & $N$ & $\mathrm{~N}$ & 300 & $\mathrm{~L}$ & $\mathrm{~N}$ & 50 & $\mathrm{~N}$ & 30 & 50 & $\mathrm{~N}$ & $\mathrm{~N}$ & $\mathrm{~N}$ & 15 & .07 & .07 & .03 & .10 \\
\hline B3024A & 3000 & $\mathrm{~N}$ & $\mathrm{~N}$ & $\mathrm{~N}$ & 150 & $\mathrm{~N}$ & $\mathrm{~N}$ & 10 & $\mathrm{~N}$ & 70 & 15 & $\mathrm{~N}$ & $\mathrm{~N}$ & $\mathrm{~N}$ & 20 & .07 & $\mathrm{~L}$ & .01 & $\mathrm{~L}$ \\
\hline B3026 & 70 & .5 & $\mathrm{~N}$ & 50 & 3000 & 1 & $\mathrm{~N}$ & 5 & 70 & 20 & 20 & $\mathrm{~N}$ & $\mathrm{~N}$ & $\mathrm{~N}$ & 10 & .07 & .07 & .3 & $\mathrm{~L}$ \\
\hline B3027A & 15 & $\mathrm{~N}$ & $\mathrm{~N}$ & 70 & 1500 & 2 & $\mathrm{~N}$ & 10 & 100 & 10 & 30 & $\mathrm{~N}$ & $\mathrm{~N}$ & $\mathrm{~N}$ & 3 & .1 & .07 & .1 & $\mathrm{~L}$ \\
\hline B3029A & 200 & $\mathrm{~N}$ & $\mathrm{~N}$ & 30 & 1000 & 2 & $\mathrm{~N}$ & L & 10 & 15 & 15 & $\mathrm{~N}$ & 500 & $\mathrm{~N}$ & 2 & .5 & 1 & .2 & $\mathrm{~N}$ \\
\hline B3030 & 150 & $\mathrm{~N}$ & $\mathrm{~N}$ & $\mathrm{~N}$ & 150 & $\mathrm{~L}$ & $\mathrm{~N}$ & $\mathrm{~L}$ & $\mathrm{~N}$ & 10 & $\mathrm{~N}$ & $\mathrm{~N}$ & $\mathrm{~N}$ & $\mathrm{~N}$ & .7 & .03 & .07 & .07 & $\mathrm{~N}$ \\
\hline B3031 & 300 & $\mathrm{~N}$ & $\mathrm{~N}$ & $\mathrm{~N}$ & 1000 & 1 & $\mathrm{~N}$ & $\mathrm{~L}$ & $\mathrm{~N}$ & 15 & 20 & $N$ & 500 & $\mathrm{~N}$ & 1 & .7 & 1 & .2 & $\mathrm{~N}$ \\
\hline B3041A & 300 & $\mathrm{~N}$ & $\mathrm{~N}$ & 300 & 300 & 1 & $\mathrm{~N}$ & 15 & 30 & 15 & 10 & $\mathrm{~N}$ & $\mathrm{~N}$ & $\mathrm{~N}$ & 5 & .2 & $\mathrm{~L}$ & .3 & $\mathrm{~N}$ \\
\hline B304 1B & 1000 & $\mathrm{~N}$ & $\mathrm{~N}$ & 150 & 2000 & 1 & $\mathrm{~N}$ & 20 & 50 & 70 & 10 & $\mathrm{~N}$ & $\mathrm{~N}$ & $\mathrm{~N}$ & 15 & .3 & .05 & .1 & $\mathrm{~L}$ \\
\hline B3042A & 1500 & 15 & $\mathrm{~N}$ & 20 & 300 & $\mathrm{~L}$ & 20 & 100 & $\mathrm{~N}$ & 20 & 150 & $\mathrm{~L}$ & $\mathrm{~N}$ & $\mathrm{~N}$ & 7 & .03 & $\mathrm{~L}$ & .01 & .40 \\
\hline B3043A & 1500 & 3 & $\mathrm{~N}$ & L & $>5000$ & $\mathrm{~N}$ & 20 & 200 & $\mathrm{~N}$ & 7 & 20 & $\mathrm{~N}$ & 1500 & $\mathrm{~N}$ & 7 & .02 & $\mathrm{~N}$ & .005 & $\mathrm{~L}$ \\
\hline В3044 & 1500 & $\mathrm{~N}$ & $\mathrm{~N}$ & 100 & 2000 & $\mathrm{~L}$ & $\mathrm{~N}$ & 30 & $\mathrm{~N}$ & 30 & 20 & $\mathrm{~N}$ & 200 & $\mathrm{~N}$ & 7 & .7 & .5 & .3 & $\mathrm{~N}$ \\
\hline B3049 & 1000 & $\mathrm{~N}$ & $\mathrm{~N}$ & $\mathrm{~N}$ & 300 & $\mathrm{~L}$ & $\mathrm{~N}$ & 500 & $\mathrm{~N}$ & 30 & 15 & $\mathrm{~N}$ & $\mathrm{~N}$ & $\mathrm{~N}$ & 20 & $\mathrm{~L}$ & $\mathrm{~N}$ & $\mathrm{~L}$ & .85 \\
\hline B3053B & 300 & $\mathrm{~N}$ & $\mathrm{~N}$ & $\mathrm{~L}$ & 2000 & 1 & $\mathrm{~N}$ & 5 & $\mathrm{~N}$ & 10 & 20 & $\mathrm{~N}$ & 700 & $\mathrm{~N}$ & 1.5 & 1 & 2 & .3 & $\mathrm{~N}$ \\
\hline B3054B & L & 10 & $\mathrm{~N}$ & $\mathrm{~L}$ & 1500 & $\mathrm{~L}$ & $\mathrm{~L}$ & 20 & 15 & L & 15 & $\mathrm{~N}$ & 200 & $\mathrm{~N}$ & 3 & .05 & .1 & .2 & $\mathrm{~L}$ \\
\hline B3056A & 1500 & 50 & $\mathrm{~N}$ & $\mathrm{~N}$ & $>5000$ & $\mathrm{~L}$ & 20 & 300 & $\mathrm{~N}$ & 15 & 700 & 150 & $>5000$ & $\mathrm{~N}$ & 10 & $\mathrm{~L}$ & $\mathrm{~L}$ & $\mathrm{~L}$ & $\mathrm{~N}$ \\
\hline
\end{tabular}




\begin{tabular}{|c|c|c|c|c|c|c|c|c|c|c|c|c|c|c|c|c|c|c|c|}
\hline \multirow[b]{2}{*}{ Sample } & \multicolumn{13}{|c|}{$(\mathrm{Ppm})$} & \multicolumn{5}{|c|}{ (Percent) } & \multirow{2}{*}{$\frac{(\mathrm{Ppm})}{\mathrm{Au}}$} \\
\hline & $\begin{array}{c}\mathrm{Mn} \\
(10)\end{array}$ & $\begin{array}{l}\mathrm{Ag} \\
(.5)\end{array}$ & $\begin{array}{c}\text { As } \\
(200)\end{array}$ & $\begin{array}{c}B \\
(10)\end{array}$ & $\begin{array}{c}\mathrm{Ba} \\
(20)\end{array}$ & $\begin{array}{r}\mathrm{Be} \\
(1)\end{array}$ & $\begin{array}{r}\mathrm{Bi} \\
\text { (1) }\end{array}$ & $\begin{array}{l}\mathrm{Cu} \\
(5)\end{array}$ & $\begin{array}{r}\text { Mo } \\
(5)\end{array}$ & $\begin{array}{r}\mathrm{Ni} \\
(5)\end{array}$ & $\begin{array}{c}\mathrm{Pb} \\
(10)\end{array}$ & $\begin{array}{c}\mathrm{Sb} \\
(100)\end{array}$ & $\begin{array}{c}\mathrm{Sr} \\
(100)\end{array}$ & $\begin{array}{c}W \\
(50)\end{array}$ & $\begin{array}{c}\mathrm{Fe} \\
(0.05)\end{array}$ & $\begin{array}{c}\mathrm{Mg} \\
(0.02)\end{array}$ & $\begin{array}{c}\mathrm{Ca} \\
(0.05)\end{array}$ & $\begin{array}{c}\mathrm{Ti} \\
(0.002)\end{array}$ & \\
\hline B3056B & 1000 & 70 & $\mathrm{~N}$ & $\mathrm{~N}$ & $>5000$ & $\mathrm{~L}$ & 70 & 500 & $\mathrm{~N}$ & 10 & 500 & 150 & 2000 & $\mathrm{~N}$ & 5 & $\mathrm{~L}$ & $\mathrm{~L}$ & .005 & $N$ \\
\hline $\mathrm{B} 3056 \mathrm{C}_{3}$ & 50 & $\mathrm{~N}$ & $\mathrm{~N}$ & 100 & 500 & $\mathrm{~L}$ & $\mathrm{~N}$ & 5 & $\mathrm{~N}$ & 15 & 10 & $\mathrm{~N}$ & $\mathrm{~N}$ & $\mathrm{~N}$ & .7 & .2 & .1 & .3 & $\mathrm{~N}$ \\
\hline B3057A & 2000 & 150 & 300 & 10 & $>5000$ & $\mathrm{~N}$ & 300 & 7000 & $\mathrm{~N}$ & 10 & 500 & 3000 & 2000 & $\mathrm{~N}$ & 5 & .07 & .05 & .02 & .05 \\
\hline B3057 $\mathrm{B}^{3}$ & 1500 & 150 & 300 & $\mathrm{~N}$ & $>5000$ & $\mathrm{~N}$ & 300 & 7000 & $\mathrm{~N}$ & 20 & 50 & 5000 & 2000 & $\mathrm{~N}$ & 10 & $\mathrm{~L}$ & $\mathrm{~N}$ & $\mathrm{~N}$ & .05 \\
\hline B $3057 C^{4}$ & 5000 & 150 & 200 & $\mathrm{~N}$ & $>5000$ & $\mathrm{~N}$ & 300 & 5000 & $\mathrm{~N}$ & 20 & 50 & 3000 & 5000 & $\mathrm{~N}$ & 10 & .1 & $\mathrm{~L}$ & $\mathrm{~N}$ & .05 \\
\hline B3058 & 20 & 1 & $\mathrm{~N}$ & 70 & 1500 & $\mathrm{~N}$ & 10 & 70 & $\mathrm{~N}$ & L & 10 & $\mathrm{~N}$ & 150 & $\mathrm{~N}$ & .5 & .15 & .1 & .1 & $\mathrm{~N}$ \\
\hline E0019A & 1000 & $\mathrm{~N}$ & $\mathrm{~N}$ & 500 & 200 & 1.5 & $\mathrm{~N}$ & 30 & $\mathrm{~N}$ & 30 & 50 & $\mathrm{~L}$ & $\mathrm{~N}$ & $\mathrm{~N}$ & 10 & .15 & .05 & .15 & $\mathrm{~L}$ \\
\hline E0031A & 1500 & $\mathrm{~N}$ & $\mathrm{~N}$ & 20 & 500 & 2 & $\mathrm{~N}$ & 10 & $\mathrm{~N}$ & 10 & L & $\mathrm{N}$ & $\mathrm{L}$ & $\mathrm{N}$ & 2 & 2 & 1.5 & .3 & $\mathrm{~L}$ \\
\hline E0031B & 700 & $\mathrm{~N}$ & $\mathrm{~N}$ & 50 & 2000 & 1.5 & $\mathrm{~N}$ & 500 & $\mathrm{~N}$ & 20 & $\mathrm{~L}$ & $\mathrm{~N}$ & $\mathrm{~L}$ & $\mathrm{~N}$ & 10 & 1 & .2 & .3 & .10 \\
\hline $\mathrm{E} 0031 \mathrm{C}$ & 500 & 2 & $\mathrm{~N}$ & 500 & 700 & 2 & 70 & 700 & 10 & 20 & 20 & $\mathrm{~N}$ & $\mathrm{~N}$ & $\mathrm{~N}$ & 15 & .3 & .07 & .2 & .06 \\
\hline E0031D & 300 & $\mathrm{~N}$ & $\mathrm{~N}$ & 300 & 1500 & 2 & $\mathrm{~N}$ & 300 & $\mathrm{~N}$ & 10 & 10 & $\mathrm{~N}$ & $\mathrm{~N}$ & $\mathrm{~N}$ & 10 & .7 & .1 & .3 & $\mathrm{~L}$ \\
\hline E0031E & 500 & $\mathrm{~N}$ & $\mathrm{~N}$ & 300 & 1500 & 2 & $\mathrm{~N}$ & 150 & 10 & 10 & $\mathrm{~L}$ & $\mathrm{~N}$ & $\mathrm{~N}$ & $\mathrm{~L}$ & 15 & .5 & .07 & .3 & .06 \\
\hline E0032A & 150 & .7 & $\mathrm{~N}$ & 100 & 3000 & 2 & $\mathrm{~N}$ & 50 & $\mathrm{~N}$ & $\mathrm{~L}$ & 15 & $\mathrm{~N}$ & 300 & $\mathrm{~N}$ & 1.5 & .5 & .5 & .2 & $\mathrm{~L}$ \\
\hline $\mathrm{E} 0033 \mathrm{~A}$ & 150 & 2 & $\mathrm{~N}$ & 70 & 100 & 7 & $\mathrm{~N}$ & 20 & 70 & 15 & 30 & 50 & $\mathrm{~N}$ & $\mathrm{~N}$ & 7 & .1 & .07 & .07 & .12 \\
\hline E0033B & 150 & 10 & $\mathrm{~N}$ & 50 & 200 & 7 & $\mathrm{~N}$ & 20 & 70 & 15 & 50 & 20 & 100 & $\mathrm{~N}$ & 10 & .07 & .07 & .03 & .60 \\
\hline$E 0033 C^{5}$ & 70 & 7 & $\mathrm{~N}$ & 70 & 1500 & 7 & L & 30 & 7 & 20 & 30 & 70 & $\mathrm{~L}$ & $\mathrm{~L}$ & 7 & .07 & .05 & .07 & 1.25 \\
\hline E0034A & 10 & $\mathrm{~N}$ & $\mathrm{~N}$ & 100 & 70 & 1.5 & $\mathrm{~N}$ & L & $\mathrm{N}$ & 5 & $\mathrm{~N}$ & $\mathrm{~N}$ & $\mathrm{~N}$ & $\mathrm{~N}$ & .3 & .15 & .2 & .2 & $\mathrm{~L}$ \\
\hline $\mathrm{E} 0035 \mathrm{~A}$ & 300 & 20 & 700 & $\mathrm{~N}$ & 1000 & 1 & 50 & 150 & 10 & 10 & 150 & 100 & $\mathrm{~N}$ & 200 & 15 & $\mathrm{~L}$ & $\mathrm{~L}$ & .003 & .60 \\
\hline E0035B & 20 & 2 & 500 & $\mathrm{~N}$ & 150 & $\mathrm{~L}$ & $\mathrm{~N}$ & 50 & $\mathrm{~N}$ & 10 & 30 & L & $\mathrm{N}$ & $\mathrm{N}$ & 7 & $\mathrm{~L}$ & $\mathrm{~N}$ & $\mathrm{~L}$ & .10 \\
\hline E0036A & 1000 & 7 & 500 & $\mathrm{~N}$ & 700 & 1.5 & 30 & 500 & $\mathrm{~N}$ & 20 & 200 & 200 & $\mathrm{~N}$ & 150 & 15 & .02 & L & .007 & .20 \\
\hline E0037A & 500 & $\mathrm{~N}$ & $\mathrm{~N}$ & $\mathrm{~N}$ & 1000 & 2 & $\mathrm{~N}$ & L & $\mathrm{N}$ & 10 & 20 & $\mathrm{~N}$ & 500 & $\mathrm{~N}$ & 1.5 & 1.5 & 1.5 & .15 & $\mathrm{~L}$ \\
\hline E0100A & 700 & $\mathrm{~N}$ & $\mathrm{~N}$ & $\mathrm{~N}$ & $>5000$ & $\mathrm{~L}$ & $\mathrm{~N}$ & 20 & $N$ & 10 & $\mathrm{~L}$ & $\mathrm{~N}$ & 3000 & $\mathrm{~N}$ & 7 & .05 & $\mathrm{~L}$ & .03 & $\mathrm{~L}$ \\
\hline E0100B & 300 & $\mathrm{~N}$ & $\mathrm{~N}$ & 500 & 300 & 3 & $\mathrm{~N}$ & L & $\mathrm{L}$ & 7 & $\mathrm{~L}$ & 70 & $\mathrm{~N}$ & $\mathrm{~N}$ & 3 & .2 & .1 & .2 & $\mathrm{~L}$ \\
\hline E0100C & 1500 & $\mathrm{~N}$ & $\mathrm{~N}$ & $\mathrm{~N}$ & $>5000$ & $\mathrm{~L}$ & $N$ & 7 & $\mathrm{~N}$ & 70 & $\mathrm{~L}$ & $\mathrm{~N}$ & 1500 & $\mathrm{~N}$ & $>20$ & .07 & .07 & .015 & $\mathrm{~L}$ \\
\hline $\mathrm{EO} 100 \mathrm{D}$ & 300 & L & $\mathrm{N}$ & 10 & $>5000$ & $\bar{L}$ & $\mathrm{~N}$ & 15 & $\mathrm{~N}$ & 15 & 10 & L & 1000 & $\mathrm{~N}$ & 7 & $\mathrm{~L}$ & $\mathrm{~L}$ & .007 & $\mathrm{~L}$ \\
\hline $\mathrm{E} 0101 \mathrm{~A}^{3}$ & 3000 & 150 & 700 & $\mathrm{~N}$ & $>5000$ & $\mathrm{~L}$ & 300 & 10000 & $\mathrm{~N}$ & 15 & 150 & 5000 & 1500 & $\mathrm{~N}$ & 7 & $\mathrm{~L}$ & $\mathrm{~L}$ & $\mathrm{~N}$ & .08 \\
\hline E0102A & 1000 & 50 & 500 & $\mathrm{~N}$ & $>5000$ & 2 & 150 & 3000 & 7 & 20 & 50 & 2000 & 300 & L & 10 & $\bar{L}$ & $\bar{L}$ & .003 & $\mathrm{~L}$ \\
\hline E202 lA & 2000 & $\mathrm{~N}$ & $\mathrm{~N}$ & $\mathrm{~N}$ & 150 & $\mathrm{~N}$ & $\mathrm{~N}$ & 5 & $\mathrm{~L}$ & 30 & $\mathrm{~N}$ & $\mathrm{~N}$ & $\mathrm{~N}$ & 100 & $>20$ & .1 & $\mathrm{~L}$ & .03 & $\mathrm{~L}$ \\
\hline E2022A & 2000 & $\mathrm{~N}$ & $\mathrm{~N}$ & $\mathrm{~N}$ & 700 & $\mathrm{~N}$ & $\mathrm{~N}$ & 15 & $\mathrm{~N}$ & 30 & $N$ & $\mathrm{~N}$ & $\mathrm{~N}$ & 50 & $>20$ & .07 & $\mathrm{~L}$ & .01 & $\mathrm{~L}$ \\
\hline E2023A & 3000 & $\mathrm{~N}$ & $\mathrm{~N}$ & $\mathrm{~N}$ & 1000 & $L$ & $\mathrm{~N}$ & 30 & $\mathrm{~N}$ & 50 & $\mathrm{~N}$ & $\mathrm{~N}$ & $\mathrm{~N}$ & L & $>20$ & .1 & .05 & .003 & $\mathrm{~L}$ \\
\hline $\mathrm{L} 2019^{2}$ & 3000 & $\mathrm{~N}$ & $\mathrm{~N}$ & $\mathrm{~N}$ & 1000 & $\mathrm{~L}$ & $\mathrm{~N}$ & 100 & $\mathrm{~N}$ & 70 & 15 & 15 & $\mathrm{~N}$ & $\mathrm{~N}$ & 20 & .1 & $\mathrm{~N}$ & .01 & .20 \\
\hline L2019A & 3000 & $\mathrm{~N}$ & $\mathrm{~N}$ & $\mathrm{~N}$ & 1000 & $\mathrm{~N}$ & $\mathrm{~N}$ & 50 & $\mathrm{~N}$ & 50 & $\mathrm{~N}$ & $\mathrm{~N}$ & $\mathrm{~N}$ & $\mathrm{~N}$ & $>20$ & .2 & L & .01 & .20 \\
\hline L2023A & 100 & 3 & $\mathrm{~N}$ & 1000 & 200 & 1.5 & $\mathrm{~N}$ & 20 & 50 & 30 & $\mathrm{~L}$ & $\mathrm{~N}$ & $\mathrm{~N}$ & $\mathrm{~N}$ & 20 & .3 & .07 & .15 & .40 \\
\hline L2028A & 3000 & $\mathrm{~N}$ & $\mathrm{~N}$ & $\mathrm{~N}$ & $>5000$ & $\mathrm{~N}$ & $\mathrm{~N}$ & 7 & 10 & 50 & $\mathrm{~N}$ & $\mathrm{~N}$ & 1000 & $\mathrm{~N}$ & $>20$ & .07 & $\mathrm{~L}$ & $\mathrm{~L}$ & .20 \\
\hline L2035A & 150 & 15 & 1000 & $\mathrm{~N}$ & 5000 & $\mathrm{~N}$ & $\mathrm{~N}$ & 70 & $\mathrm{~N}$ & 10 & 500 & 100 & $\mathrm{~N}$ & 50 & 20 & $\mathrm{~L}$ & $\mathrm{~L}$ & .005 & .80 \\
\hline
\end{tabular}


Table 4. Semiquantitative spectrographic analyses for selected elements and atomic absorption analyses for gold in grab samples of altered rock or vein-Continued

\begin{tabular}{|c|c|c|c|c|c|c|c|c|c|c|c|c|c|c|c|c|c|c|c|}
\hline \multirow[b]{2}{*}{ Sample } & \multicolumn{13}{|c|}{$(\mathrm{Ppm})$} & \multirow[b]{2}{*}{$\begin{array}{c}W \\
(50)\end{array}$} & \multicolumn{4}{|c|}{ (Percent) } & \multirow{2}{*}{$\frac{(\mathrm{Ppm})}{\mathrm{Au}}$} \\
\hline & $\begin{array}{l}\mathrm{Mn} \\
(10)\end{array}$ & $\begin{array}{l}\mathrm{Ag} \\
(.5)\end{array}$ & $\begin{array}{c}\text { As } \\
(200)\end{array}$ & $\begin{array}{c}\text { B } \\
(10)\end{array}$ & $\begin{array}{c}\mathrm{Ba} \\
(20)\end{array}$ & $\begin{array}{l}\mathrm{Be} \\
(1)\end{array}$ & $\begin{array}{r}\mathrm{Bi} \\
(1)\end{array}$ & $\begin{array}{r}\mathrm{Cu} \\
(5)\end{array}$ & $\begin{array}{r}\text { Mo } \\
(5)\end{array}$ & $\begin{array}{r}\mathrm{Ni} \\
(5)\end{array}$ & $\begin{array}{c}\mathrm{Pb} \\
(10)\end{array}$ & $\begin{array}{c}\mathrm{Sb} \\
(100)\end{array}$ & $\begin{array}{c}\mathrm{Sr} \\
(100)\end{array}$ & & $\begin{array}{c}\mathrm{Fe} \\
(0.05)\end{array}$ & $\begin{array}{c}M g \\
(0.02)\end{array}$ & $\begin{array}{c}\mathrm{Ca} \\
(0.05)\end{array}$ & $\begin{array}{c}\mathrm{Ti} \\
(0.002)\end{array}$ & \\
\hline $\mathrm{L} 2035 \mathrm{~B}^{2}$ & 300 & 10 & 200 & 20 & 5000 & $\mathrm{~N}$ & $\mathrm{~L}$ & 70 & $\mathrm{~N}$ & 15 & 200 & $\mathrm{~L}$ & L & 100 & 5 & .02 & $\mathrm{~L}$ & .02 & .25 \\
\hline L2036A & 500 & 10 & $\mathrm{~N}$ & $\mathrm{~N}$ & $>5000$ & $\mathrm{~N}$ & 20 & 500 & $\mathrm{~N}$ & 30 & 30 & $\mathrm{~N}$ & 700 & $\mathrm{~N}$ & 20 & .03 & $\mathrm{~L}$ & .015 & .10 \\
\hline L2036B & 200 & 5 & $\mathrm{~N}$ & 700 & $>5000$ & 3 & $\mathrm{~L}$ & 15 & 7 & 10 & 20 & $\mathrm{~N}$ & $\mathrm{~N}$ & $\mathrm{~N}$ & 2 & .5 & $\mathrm{~L}$ & .5 & .10 \\
\hline L2047A & 1500 & $\mathrm{~N}$ & $\mathrm{~N}$ & $\mathrm{~N}$ & 300 & $\mathrm{~N}$ & $N$ & 10 & $\mathrm{~N}$ & 30 & $\mathrm{~N}$ & $\mathrm{~N}$ & $\mathrm{~N}$ & $\mathrm{~N}$ & $>20$ & .05 & $\mathrm{~L}$ & .005 & .05 \\
\hline L2048A & 2000 & $\mathrm{~N}$ & $\mathrm{~N}$ & $\mathrm{~N}$ & 200 & $\mathrm{~N}$ & $\mathrm{~N}$ & 5 & 10 & 30 & $\mathrm{~N}$ & $\mathrm{~N}$ & $\mathrm{~N}$ & $\mathrm{~N}$ & $>20$ & .07 & $\mathrm{~L}$ & .005 & .10 \\
\hline L2049A & 5000 & $\mathrm{~N}$ & $\mathrm{~N}$ & $\mathrm{~N}$ & 500 & $\mathrm{~N}$ & $\mathrm{~N}$ & 30 & $\mathrm{~N}$ & 50 & $\mathrm{~N}$ & $\mathrm{~N}$ & $\mathrm{~N}$ & $\mathrm{~N}$ & $>20$ & .05 & $\mathrm{~L}$ & .002 & .05 \\
\hline L2050A & 5000 & $\mathrm{~N}$ & $\mathrm{~N}$ & 50 & 700 & $\mathrm{~L}$ & $\mathrm{~N}$ & 15 & $\mathrm{~N}$ & 30 & $\mathrm{~N}$ & $\mathrm{~N}$ & $\mathrm{~N}$ & $\mathrm{~N}$ & $>20$ & .1 & .05 & .07 & .10 \\
\hline $\mathrm{L} 2051 \mathrm{~A}$ & 5000 & $\mathrm{~N}$ & $\mathrm{~N}$ & $\mathrm{~N}$ & 500 & $\mathrm{~L}$ & $\mathrm{~N}$ & 15 & $\mathrm{~N}$ & 30 & $\mathrm{~N}$ & $\mathrm{~N}$ & $\mathrm{~N}$ & $\mathrm{~N}$ & $>20$ & .07 & $\mathrm{~L}$ & .007 & .05 \\
\hline $\mathrm{L} 2053 \mathrm{~A}$ & 5000 & $\mathrm{~N}$ & $\mathrm{~N}$ & $\mathrm{~N}$ & 700 & $\mathrm{~N}$ & $\mathrm{~N}$ & 20 & $\mathrm{~N}$ & 30 & $\mathrm{~N}$ & $\mathrm{~N}$ & $\mathrm{~N}$ & $\mathrm{~N}$ & $>20$ & .07 & $\mathrm{~L}$ & .007 & .30 \\
\hline$L 2053 B^{2}$ & 5000 & $\mathrm{~N}$ & $\mathrm{~N}$ & $\mathrm{~N}$ & 500 & $\mathrm{~L}$ & $N$ & 300 & $\mathrm{~N}$ & 50 & 20 & L & $\mathrm{N}$ & $\mathrm{N}$ & 20 & .07 & .05 & .01 & .25 \\
\hline L2057A & 5000 & $\mathrm{~N}$ & $\mathrm{~N}$ & $\mathrm{~N}$ & 700 & $\mathrm{~N}$ & $\mathrm{~N}$ & 5 & $\mathrm{~N}$ & 30 & $\mathrm{~N}$ & $\mathrm{~N}$ & $\mathrm{~N}$ & $\mathrm{~N}$ & $>20$ & .07 & $\mathrm{~L}$ & .003 & .05 \\
\hline L2067 & 2000 & $\mathrm{~N}$ & $\mathrm{~N}$ & $\mathrm{~N}$ & 200 & $\mathrm{~N}$ & $\mathrm{~N}$ & 3000 & $\mathrm{~N}$ & 7 & 15 & $\mathrm{~N}$ & $\mathrm{~N}$ & $\mathrm{~N}$ & 15 & $\mathrm{~L}$ & $\mathrm{~L}$ & $\mathrm{~N}$ & -- \\
\hline L2073A & 2000 & $\mathrm{~N}$ & $\mathrm{~N}$ & $\mathrm{~N}$ & 5000 & $\mathrm{~N}$ & $\mathrm{~N}$ & 15 & $\mathrm{~N}$ & 15 & $\mathrm{~N}$ & $\mathrm{~N}$ & $\mathrm{~N}$ & $\mathrm{~N}$ & 20 & .03 & $\mathrm{~L}$ & .003 & -- \\
\hline $\mathrm{L} 2074^{2}$ & 700 & 4 & $\mathrm{~N}$ & 100 & 200 & 2 & $\mathrm{~N}$ & 15 & 20 & 30 & 20 & $\mathrm{~N}$ & $\mathrm{~N}$ & $\mathrm{~N}$ & 7 & .1 & .05 & .07 & .15 \\
\hline L2092 & 100 & $\mathrm{~L}$ & $\mathrm{~N}$ & 1000 & 20 & 2 & $\mathrm{~N}$ & 5 & $\mathrm{~N}$ & 5 & 10 & $\mathrm{~N}$ & $\mathrm{~N}$ & $N$ & .5 & .2 & .05 & .2 & -- \\
\hline L2093 & 2000 & $\mathrm{~N}$ & $\mathrm{~N}$ & $\mathrm{~N}$ & 3000 & $\mathrm{~N}$ & $\mathrm{~N}$ & $\mathrm{~L}$ & $\mathrm{~N}$ & 20 & $\mathrm{~L}$ & $\mathrm{~N}$ & $\mathrm{~N}$ & $\mathrm{~N}$ & 20 & $\mathrm{~L}$ & $\mathrm{~L}$ & .002 & -- \\
\hline L2098A & 150 & $\mathrm{~N}$ & $\mathrm{~N}$ & 50 & 200 & $\mathrm{~N}$ & $\mathrm{~N}$ & $\mathrm{~L}$ & $\mathrm{~N}$ & 10 & $\mathrm{~L}$ & $\mathrm{~N}$ & $\mathrm{~N}$ & $\mathrm{~N}$ & 3 & .05 & .05 & .05 & -- \\
\hline $\mathrm{L} 2107^{2}$ & 1000 & $\mathrm{~N}$ & $\mathrm{~N}$ & 150 & $>5000$ & $\mathrm{~L}$ & $\mathrm{~N}$ & 15 & $\mathrm{~N}$ & 20 & 20 & $\mathrm{~N}$ & 1000 & $\mathrm{~N}$ & 10 & .05 & .07 & .05 & $\mathrm{~N}$ \\
\hline $\mathrm{L} 2111^{2}$ & 700 & $\mathrm{~N}$ & $\mathrm{~N}$ & 300 & 500 & 1 & $\mathrm{~N}$ & 15 & $\mathrm{~N}$ & 20 & 20 & $\mathrm{~N}$ & $\mathrm{~N}$ & $\mathrm{~N}$ & 7 & .07 & .07 & .1 & $\mathrm{~N}$ \\
\hline $\mathrm{L} 2112^{2}$ & 5000 & 20 & $\mathrm{~N}$ & $\mathrm{~N}$ & 500 & $\mathrm{~N}$ & $\mathrm{~N}$ & 500 & $\mathrm{~N}$ & 50 & 30 & 100 & $\mathrm{~N}$ & $\mathrm{~N}$ & 20 & .07 & .07 & $\mathrm{~L}$ & $\mathrm{~N}$ \\
\hline L2131A & 3000 & $\mathrm{~N}$ & $\mathrm{~N}$ & $\mathrm{~N}$ & 200 & $\mathrm{~N}$ & $\mathrm{~N}$ & 20 & $\mathrm{~N}$ & 70 & L & $\mathrm{N}$ & $\mathrm{N}$ & $\mathrm{N}$ & $>20$ & .02 & $\mathrm{~L}$ & .002 & -- \\
\hline L3004 & 300 & $\mathrm{~N}$ & $\mathrm{~N}$ & $\mathrm{~N}$ & $>5000$ & 1 & $\mathrm{~N}$ & $\mathrm{~L}$ & 10 & 10 & 10 & $\mathrm{~N}$ & 5000 & $\mathrm{~N}$ & 2 & $\mathrm{~L}$ & $\mathrm{~L}$ & .005 & $\mathrm{~N}$ \\
\hline L $3024 A$ & 10 & 10 & $\mathrm{~N}$ & $\mathrm{~N}$ & 700 & $\mathrm{~L}$ & 200 & 30 & 20 & 7 & 15 & $\mathrm{~N}$ & $\mathrm{~N}$ & $\mathrm{~L}$ & 3 & $\mathrm{~L}$ & $\mathrm{~L}$ & .005 & .05 \\
\hline L.3024B & 10 & .7 & $\mathrm{~N}$ & $\mathrm{~N}$ & 100 & $\mathrm{~L}$ & 70 & 10 & $\mathrm{~N}$ & 5 & 15 & $\mathrm{~N}$ & $\mathrm{~N}$ & $\mathrm{~N}$ & 3 & $\mathrm{~L}$ & $\mathrm{~L}$ & $\mathrm{~L}$ & $\mathrm{~L}$ \\
\hline L $3025 \mathrm{~A}$ & 50 & $\mathrm{~N}$ & $\mathrm{~N}$ & 200 & 150 & 1 & $\mathrm{~L}$ & 50 & $\mathrm{~N}$ & 20 & L & $\mathrm{N}$ & $\mathrm{N}$ & 50 & 2 & .3 & .1 & .5 & .20 \\
\hline L3025B & 100 & $\mathrm{~N}$ & $\mathrm{~N}$ & $\mathrm{~L}$ & 50 & $\mathrm{~N}$ & $\mathrm{~N}$ & $\mathrm{~L}$ & $\mathrm{~N}$ & 7 & 10 & $\mathrm{~N}$ & $\mathrm{~N}$ & $\mathrm{~L}$ & .7 & .02 & $\mathrm{~L}$ & .002 & $\mathrm{~L}$ \\
\hline $\mathrm{L} 3025 \mathrm{C}$ & 15 & 1.5 & $\mathrm{~N}$ & 10 & 200 & 3 & $\mathrm{~N}$ & 7 & $\mathrm{~N}$ & 50 & 10 & $\mathrm{~N}$ & $\mathrm{~N}$ & $\mathrm{~N}$ & .7 & .02 & $\mathrm{~L}$ & $\mathrm{~L}$ & $\mathrm{~L}$ \\
\hline L302 5D & 50 & 2 & $\mathrm{~N}$ & $\mathrm{~N}$ & 200 & $\mathrm{~N}$ & 200 & 700 & 50 & 50 & 30 & $\mathrm{~N}$ & $\mathrm{~N}$ & 70 & 15 & .05 & .07 & .005 & 1.4 \\
\hline L3025E & 20 & .7 & $\mathrm{~N}$ & 70 & 300 & $\mathrm{~L}$ & $\mathrm{~N}$ & L & $\mathrm{N}$ & 10 & $\mathrm{~N}$ & $\mathrm{~N}$ & $\mathrm{~N}$ & $\mathrm{~N}$ & .3 & .1 & .07 & .07 & $\mathrm{~N}$ \\
\hline L3028 & 1000 & $\mathrm{~N}$ & $\mathrm{~N}$ & $\mathrm{~N}$ & $>5000$ & $\mathrm{~N}$ & $\mathrm{~N}$ & 5 & $\mathrm{~N}$ & 70 & 10 & $\mathrm{~N}$ & 200 & $\mathrm{~N}$ & 20 & .05 & .05 & .01 & .80 \\
\hline L3030 & 1000 & $\mathrm{~N}$ & $\mathrm{~N}$ & 15 & 1000 & 1.5 & $\mathrm{~N}$ & $\mathrm{~L}$ & $\mathrm{~N}$ & 5 & 30 & $\mathrm{~N}$ & 300 & $\mathrm{~N}$ & 1 & .5 & 1 & .5 & $\mathrm{~N}$ \\
\hline L3047 & 500 & $\mathrm{~N}$ & $\mathrm{~N}$ & 100 & 500 & 1.5 & $\mathrm{~N}$ & L & $\mathrm{N}$ & 15 & 10 & $\mathrm{~N}$ & 150 & $\mathrm{~N}$ & 1 & .3 & .2 & .3 & $\mathrm{~N}$ \\
\hline L3049B & 700 & 15 & $\mathrm{~N}$ & $\mathrm{~N}$ & 100 & 1.5 & $\mathrm{~N}$ & 200 & $\mathrm{~N}$ & 50 & 20 & L & $\mathrm{N}$ & $\mathrm{N}$ & 20 & .02 & $\mathrm{~L}$ & $\mathrm{~L}$ & $\mathrm{~L}$ \\
\hline L3058 & 200 & 10 & $\mathrm{~N}$ & $\mathrm{~N}$ & 150 & $\mathrm{~L}$ & 10 & 300 & $\mathrm{~N}$ & 5 & 10 & 200 & $\mathrm{~N}$ & $\mathrm{~N}$ & 1 & $\mathrm{~L}$ & $\mathrm{~L}$ & .003 & $\mathrm{~N}$ \\
\hline$L 3059^{6}$ & 2000 & 150 & 2000 & $\mathrm{~N}$ & $>5000$ & 2 & 500 & 15000 & $\mathrm{~N}$ & 20 & 100 & 7000 & 500 & $\mathrm{~N}$ & 15 & $\mathrm{~L}$ & .05 & $\mathrm{~L}$ & 1.5 \\
\hline
\end{tabular}

\footnotetext{
${ }^{1}$ Sample of vein cobbles from alluvium.

${ }^{2}$ Split from bulk sample of vein.

$3_{A}$ Also contains $700 \mathrm{ppm} \mathrm{Zn}$.

${ }_{5}^{4} \mathrm{Also}$ contains $300 \mathrm{ppm} \mathrm{Zn}$.

${ }^{5}$ Also contains $5000 \mathrm{ppm} \mathrm{Zn}$.

${ }^{6}$ Also contains $1000 \mathrm{ppm} \mathrm{Zn}$.
} 
Table 5. Atomic absorption analyses for selected elements in grab samples of altered rock or vein

\begin{tabular}{|c|c|c|c|c|c|c|}
\hline \multirow[b]{2}{*}{ Sample } & \multicolumn{4}{|c|}{ (Ppm) } & \multirow[b]{2}{*}{$\begin{array}{r}\mathrm{Sb} \\
(1)\end{array}$} & \multirow[b]{2}{*}{$\begin{array}{l}\text { As } \\
\text { (5) }\end{array}$} \\
\hline & $\begin{array}{c}\mathrm{Hg} \\
(0.02)\end{array}$ & $\begin{array}{l}\mathrm{Zn} \\
(5)\end{array}$ & $\begin{array}{c}C d \\
(0.02)\end{array}$ & $\begin{array}{r}\mathrm{Bi} \\
(2)\end{array}$ & & \\
\hline B2024A & 0.06 & 45 & 0.5 & $\mathrm{~L}$ & 5 & 30 \\
\hline B2028A & .08 & 20 & .5 & $L$ & 4 & 40 \\
\hline B2029A & .2 & 70 & 1.2 & 26 & 55 & 45 \\
\hline $\mathrm{B} 2030 \mathrm{~A}$ & .04 & 30 & .6 & $\mathrm{~L}$ & 3 & 30 \\
\hline B2038A & .08 & 260 & 1.0 & 2 & 5 & 60 \\
\hline $\mathrm{B} 2039 \mathrm{~A}$ & .04 & 30 & .6 & $\mathrm{~N}$ & 2 & 20 \\
\hline B2040A & .04 & 10 & .3 & $\mathrm{~N}$ & 25 & L \\
\hline B2046 & $\mathrm{L}$ & 90 & .6 & 2 & 46 & 60 \\
\hline B2048A & .06 & 45 & 1.0 & $\mathrm{~N}$ & 2 & 45 \\
\hline B2049A & .08 & 50 & 1.0 & L & 12 & 65 \\
\hline B2050A & .16 & 70 & .4 & $\mathrm{~N}$ & 34 & 35 \\
\hline B2051A & .04 & 10 & 1.0 & $\mathrm{~N}$ & 3 & 30 \\
\hline B2054A & .16 & 190 & .3 & $\mathrm{~L}$ & 11 & 140 \\
\hline B2056B & .02 & 100 & .3 & $\mathrm{~N}$ & $\mathrm{~N}$ & 15 \\
\hline B2058A & .06 & 25 & .7 & $\mathrm{~N}$ & 23 & 140 \\
\hline B2063 & .08 & 15 & .1 & 4 & 6 & 20 \\
\hline B2064 & .14 & 30 & .4 & $\mathrm{~L}$ & 64 & 540 \\
\hline B2131A & .14 & 20 & .1 & $\mathrm{~N}$ & 8 & 170 \\
\hline B2 $131 \mathrm{~B}$ & .02 & 10 & $\mathrm{~N}$ & $\mathrm{~N}$ & 3 & 5 \\
\hline B2133 & .64 & 15 & .7 & 50 & 26 & 80 \\
\hline B2134 & .18 & 60 & 4.5 & 2 & 10 & 65 \\
\hline B21352 & .02 & 15 & .4 & $\mathrm{~L}$ & 8 & 35 \\
\hline B2 140 & .08 & 10 & $\mathrm{~N}$ & $N$ & 3 & 30 \\
\hline B2141 & .02 & 5 & .1 & $\mathrm{~N}$ & 4 & 10 \\
\hline B2 142 & .06 & 25 & .4 & $\mathrm{~N}$ & 6 & 40 \\
\hline B2 $144^{1}$ & .04 & 30 & .6 & $\mathrm{~N}$ & 4 & 15 \\
\hline $\mathrm{E} 2021 \mathrm{~A}$ & .04 & 20 & .4 & $N$ & 4 & 30 \\
\hline E2022A & .10 & 110 & .7 & 2 & 5 & 35 \\
\hline E $2023 \mathrm{~A}$ & .12 & 90 & 1.1 & $\mathrm{~N}$ & 8 & 55 \\
\hline $\mathrm{L} 2019^{2}$ & .10 & 30 & .7 & $\mathrm{~L}$ & 17 & 160 \\
\hline L2019A & .02 & 30 & .8 & $\mathrm{~L}$ & 12 & 90 \\
\hline L2023A & .02 & 40 & .6 & 6 & $\mathrm{~N}$ & 75 \\
\hline L2028A & .02 & 15 & .5 & $\mathrm{~N}$ & $\mathrm{~N}$ & 25 \\
\hline L2035A & .12 & 25 & .6 & 6 & 32 & 900 \\
\hline $\mathrm{L} 2035 \mathrm{~B}^{2}$ & .18 & 20 & .4 & 6 & 33 & 220 \\
\hline L2036A & 0.06 & 30 & 0.5 & 24 & 7 & 170 \\
\hline L2036B & .02 & 15 & .5 & 4 & 5 & 40 \\
\hline L2047A & .04 & 45 & .6 & $\mathrm{~N}$ & 2 & 40 \\
\hline L2048A & .02 & 30 & .6 & $\mathrm{~N}$ & $\mathrm{~N}$ & 45 \\
\hline L2049A & .04 & 30 & .6 & 4 & 3 & 60 \\
\hline L $2050 \mathrm{~A}$ & $\mathrm{~L}$ & 40 & .7 & $\mathrm{~N}$ & 4 & 25 \\
\hline L2051A & $\mathrm{L}$ & 80 & .8 & $\mathrm{~N}$ & 3 & 25 \\
\hline L2053A & .02 & 110 & .7 & $\mathrm{~N}$ & 10 & 25 \\
\hline$L 2053 B^{2}$ & 2.0 & 350 & 1.2 & $\mathrm{~N}$ & 80 & 70 \\
\hline L2057A & $\mathrm{L}$ & 25 & .5 & $\mathrm{~L}$ & L & 20 \\
\hline L2067 & .04 & 25 & .6 & $\mathrm{~N}$ & 20 & 75 \\
\hline L207 3A & .10 & 40 & .1 & $\mathrm{~N}$ & 2 & 10 \\
\hline $\mathrm{L} 2074^{2}$ & .12 & 50 & .8 & $\mathrm{~L}$ & 4 & 55 \\
\hline L2092 & .04 & 5 & $\mathrm{~N}$ & $\mathrm{~N}$ & 12 & 10 \\
\hline L2093 & .06 & 25 & .3 & $\mathrm{~N}$ & 3 & 35 \\
\hline L2098A & .08 & 10 & .1 & $\mathrm{~N}$ & 3 & 5 \\
\hline $\mathrm{L} 2107^{2}$ & .08 & 15 & .3 & $\mathrm{~N}$ & 16 & 25 \\
\hline $\mathrm{L} 211 \mathrm{l}^{2}$ & .04 & 15 & .4 & $\mathrm{~N}$ & 29 & 20 \\
\hline $\mathrm{L} 2112^{2}$ & $>6.0$ & 130 & 2.1 & 6 & 160 & 75 \\
\hline L2131A & .16 & 35 & .2 & $\mathrm{~N}$ & 7 & 30 \\
\hline
\end{tabular}

\footnotetext{
${ }^{1}$ Sample of vein cobbles from alluvium.

${ }^{2}$ Split from bulk sample of vein.
}

and zinc) and SQS analysis for three elements (copper, iron, and barium) in 53 samples (see tables 4 and 5).
Linear correlation coefficients were computed for the elements for which concentrations in each sample pair were unqualified (that is, not qualified by $\mathrm{N}$ (not detected), L (less than detection limit), or blank (no analysis)). Correlation coefficients greater than 0.3 were considered significant; only those correlations based on more than half of the 53 sample pairs $(>27)$ are given in table 13.

A strong element association exists among antimony, arsenic, copper, and mercury.

A separate correlation analysis used 51 samples containing detectable gold (table 16). A significant positive correlation $(>10$ percent of data variability explained at a confidence level of $>95$ percent) is indicated between gold and arsenic and between gold and antimony. An inverse correlation exists between gold and strontium.

\section{Discussion of Geochemical Maps}

Geochemical maps show the distribution of antimony and arsenic (the suggested element association derived from correlations of sample analyses). Maps also show the distribution of barium, gold, molybdenum, and tungsten. The maps suggest weak concentric zoning around the pervasively altered zone, and weak northwestsoutheast linear trends, which are concordant to joint trends.

The detectable amounts of antimony and arsenic (fig. 11) were concentrated around the east margin of the stock, and along possible northwest-southeast linear trends. Antimony and arsenic were not detected within the pervasively altered zone.

The distribution of detectable gold (fig. 12) shows its low concentration within the pervasively altered area. The significant correlations of gold with antimony and arsenic (table 14) indicate that gold occurs in the veins that also contain antimony and arsenic, and suggest that a chemical association exists between gold and the antimony-arsenic element association.

High barium values are widespread in the Miners Gulch area, both inside and outside of the pervasively altered zone (fig. 13).

The molybdenum map (fig. 14) shows that the highest concentration of molybdenum is located within or adjacent to the pervasively altered zone. A smaller concentration of high molybdenum values lies approximately $1 \mathrm{mi}$ southeast of the center of the alteration zone. This pattern, when considered with the barite map, indicates that molybdenum and barite tend to occur together.

The distribution of tungsten in geochemical samples (fig. 15) shows low concentrations except for two groups and two single samples with high values located in a possible concentric pattern around the pervasively altered zone at a radius of $1.5 \mathrm{mi}$. 
Table 6. Semiquantitative spectrographic analyses for selected elements and atomic absorption analyses for gold in panned concentrates of stream-sediment samples

\begin{tabular}{|c|c|c|c|c|c|c|c|c|c|c|c|c|c|c|c|c|c|c|}
\hline \multirow[b]{2}{*}{ Sample } & \multicolumn{13}{|c|}{ (Ppm) } & \multicolumn{4}{|c|}{ (Percent) } & \multirow{2}{*}{$\frac{(\mathrm{Ppm})}{\mathrm{Au}}$} \\
\hline & $\begin{array}{l}\mathrm{Mn} \\
(10)\end{array}$ & $\begin{array}{l}\mathrm{Ag} \\
(.5)\end{array}$ & $\begin{array}{l}\text { As } \\
(200)\end{array}$ & $\begin{array}{c}B \\
(10)\end{array}$ & $\begin{array}{l}\mathrm{Ba} \\
(20)\end{array}$ & $\begin{array}{l}\mathrm{Be} \\
(1)\end{array}$ & $\begin{array}{l}B i \\
(1)\end{array}$ & $\begin{array}{l}\mathrm{Cu} \\
(5)\end{array}$ & $\begin{array}{l}\text { Mo } \\
\text { (5) }\end{array}$ & $\begin{array}{l}\mathrm{Ni} \\
(5)\end{array}$ & $\begin{array}{c}\mathrm{Pb} \\
(10)\end{array}$ & $\begin{array}{l}\mathrm{Sr} \\
(100)\end{array}$ & $\begin{array}{l}\text { W } \\
(50)\end{array}$ & $\begin{array}{c}F e \\
(0.05)\end{array}$ & $\begin{array}{c}\mathrm{Mg} \\
(0.02)\end{array}$ & $\begin{array}{c}\mathrm{Ca} \\
(0.05)\end{array}$ & $\begin{array}{c}\mathrm{Ti} \\
(0.002)\end{array}$ & \\
\hline AL2 385 & 1000 & $\mathrm{~N}$ & $\mathrm{~N}$ & 50 & 700 & $\mathrm{~L}$ & $\mathrm{~N}$ & 10 & $\mathrm{~N}$ & 10 & 20 & 300 & $\mathrm{~L}$ & 7 & 1.5 & 3 & 1 & $\mathrm{~L}$ \\
\hline AL2387 & 700 & $\mathrm{~N}$ & $\mathrm{~N}$ & 20 & 300 & $\mathrm{~N}$ & $\mathrm{~N}$ & $\mathrm{~L}$ & $\mathrm{~N}$ & 10 & $\mathrm{~L}$ & $\mathrm{~N}$ & $\mathrm{~N}$ & 10 & .7 & 1 & .5 & 0.06 \\
\hline AL2 388 & 1000 & $\mathrm{~N}$ & $\mathrm{~N}$ & 20 & 500 & $\mathrm{~N}$ & $\mathrm{~N}$ & 10 & $\mathrm{~N}$ & 10 & $\mathrm{~L}$ & $\mathrm{~L}$ & $\mathrm{~N}$ & 15 & 1.5 & 3 & .7 & 2.1 \\
\hline AL2389 & 1000 & $\mathrm{~N}$ & $\mathrm{~N}$ & 50 & 500 & $\mathrm{~N}$ & $\mathrm{~N}$ & 20 & $\mathrm{~N}$ & 50 & $\mathrm{~L}$ & $\mathrm{~L}$ & $\mathrm{~N}$ & 20 & 1 & 2 & 1 & 1.6 \\
\hline AL2391 & 700 & $\mathrm{~N}$ & $\mathrm{~N}$ & 50 & 500 & $\mathrm{~L}$ & $\mathrm{~N}$ & 10 & $\mathrm{~N}$ & 50 & 20 & $\mathrm{~L}$ & $\mathrm{~N}$ & 10 & 1 & 2 & 1.5 & $\mathrm{~L}$ \\
\hline AL2393 & 1500 & $\mathrm{~N}$ & $\mathrm{~N}$ & 50 & 5000 & $\mathrm{~L}$ & 50 & 20 & $\mathrm{~N}$ & 50 & $\mathrm{~L}$ & 700 & $\mathrm{~N}$ & 15 & 3 & 7 & 1.5 & $\mathrm{~L}$ \\
\hline AL2 395 & 1500 & $\mathrm{~N}$ & $\mathrm{~N}$ & 50 & 1000 & $\mathrm{~L}$ & 500 & 20 & $\mathrm{~N}$ & 50 & 20 & 700 & 200 & 15 & 2 & 5 & 1 & .2 \\
\hline AL2397 & 1000 & $\mathrm{~N}$ & $\mathrm{~N}$ & 50 & 1000 & $\mathrm{~L}$ & $\mathrm{~N}$ & 15 & $\mathrm{~N}$ & 30 & $\mathrm{~L}$ & 500 & L & 7 & 3 & 5 & 1 & 2.0 \\
\hline AL2753 & 2000 & $\mathrm{~N}$ & $\mathrm{~N}$ & 100 & 500 & L & $\mathrm{N}$ & 20 & $\mathrm{~N}$ & 30 & 30 & 300 & $\mathrm{~N}$ & 15 & 2 & 5 & 1.5 & $\mathrm{~L}$ \\
\hline AL2755 & 1000 & $\mathrm{~N}$ & $\mathrm{~N}$ & 20 & 10000 & $\mathrm{~L}$ & $\mathrm{~N}$ & 15 & $\mathrm{~N}$ & 50 & 30 & 1000 & $\mathrm{~N}$ & 30 & 1.5 & 3 & 1.5 & $\mathrm{~L}$ \\
\hline AL2 774 & 2000 & $\mathrm{~N}$ & $\mathrm{~N}$ & 70 & 500 & $\mathrm{~N}$ & $\mathrm{~N}$ & 30 & $\mathrm{~N}$ & 70 & 20 & 200 & $\mathrm{~N}$ & 20 & 3 & 5 & 1 & .17 \\
\hline E2024B & 3000 & $\mathrm{~N}$ & $\mathrm{~N}$ & 150 & 2000 & $\mathrm{~N}$ & $\mathrm{~N}$ & 50 & $\mathrm{~N}$ & 70 & 50 & $\mathrm{~N}$ & $\mathrm{~N}$ & 30 & 1.5 & 1.5 & .7 & .95 \\
\hline E2025B & 5000 & $\mathrm{~N}$ & $\mathrm{~N}$ & 100 & 700 & $\mathrm{~N}$ & $\mathrm{~N}$ & 30 & $\mathrm{~N}$ & 50 & 50 & L & $\mathrm{N}$ & 30 & 1.5 & 2 & .5 & .25 \\
\hline E2026B & 2000 & 2 & $\mathrm{~N}$ & 150 & $>10000$ & $\mathrm{~N}$ & $\mathrm{~N}$ & 200 & $\mathrm{~N}$ & 50 & 700 & 1500 & $\mathrm{~N}$ & 20 & .7 & .5 & .5 & .50 \\
\hline
\end{tabular}


Table 7. Semiquantitative spectrographic analyses for selected elements in panned concentrates of stream-sediment samples, fraction magnetic at 0.6 amperes

\begin{tabular}{|c|c|c|c|c|c|c|c|c|c|c|c|c|c|c|c|c|c|c|}
\hline \multirow[b]{2}{*}{ Sample } & \multicolumn{13}{|c|}{$(\mathrm{Ppm})$} & \multirow[b]{2}{*}{$\begin{array}{c}W \\
(50)\end{array}$} & \multicolumn{4}{|c|}{ (Percent) } \\
\hline & $\begin{array}{c}\text { Mn } \\
(10)\end{array}$ & $\begin{array}{c}\mathrm{Au} \\
(10)\end{array}$ & $\begin{array}{c}\mathrm{Ag} \\
(.5)\end{array}$ & $\begin{array}{l}\text { As } \\
(200)\end{array}$ & $\begin{array}{l}B \\
(10)\end{array}$ & $\begin{array}{c}\mathrm{Ba} \\
(20)\end{array}$ & $\begin{array}{l}\mathrm{Be} \\
(1)\end{array}$ & $\begin{array}{l}\mathrm{Bi} \\
(1)\end{array}$ & $\begin{array}{l}\mathrm{Cu} \\
(5)\end{array}$ & $\begin{array}{l}\text { Mo } \\
\text { (5) }\end{array}$ & $\begin{array}{l}\mathrm{Ni} \\
(5)\end{array}$ & $\begin{array}{l}\mathrm{Pb} \\
(10)\end{array}$ & $\begin{array}{l}\mathrm{Sr} \\
(100)\end{array}$ & & $\begin{array}{c}\mathrm{Fe} \\
(0.05)\end{array}$ & $\begin{array}{c}\mathrm{Mg} \\
(0.02)\end{array}$ & $\begin{array}{l}\mathrm{Ca} \\
(0.05)\end{array}$ & $\begin{array}{c}\mathrm{Ti} \\
(0.002)\end{array}$ \\
\hline AL4 204 & 500 & $\mathrm{~N}$ & $\mathrm{~N}$ & $\mathrm{~N}$ & $\mathrm{~L}$ & 700 & $\mathrm{~N}$ & $\mathrm{~N}$ & 30 & 20 & $\mathrm{~N}$ & 20 & $\mathrm{~N}$ & $\mathrm{~N}$ & .7 & .3 & 10 & $>2$ \\
\hline AL 4206 & 200 & $\mathrm{~N}$ & $\mathrm{~N}$ & $\mathrm{~N}$ & $\mathrm{~L}$ & 50 & $\mathrm{~N}$ & $\mathrm{~N}$ & 10 & $\mathrm{~N}$ & $\mathrm{~N}$ & $\mathrm{~L}$ & $\mathrm{~N}$ & $\mathrm{~N}$ & .3 & .2 & 5 & $>2$ \\
\hline AL4208 & 700 & $\mathrm{~N}$ & $\mathrm{~N}$ & $\mathrm{~N}$ & 500 & 150 & $\mathrm{~L}$ & $\mathrm{~N}$ & 15 & 10 & $\mathrm{~L}$ & $\mathrm{~L}$ & $\mathrm{~N}$ & $\mathrm{~N}$ & 2 & .7 & 7 & $>2$ \\
\hline AL4210 & 500 & 70 & 10 & $\mathrm{~N}$ & 500 & 150 & 3 & $\mathrm{~N}$ & 15 & 10 & $\mathrm{~L}$ & 20 & $\mathrm{~N}$ & $\mathrm{~L}$ & 1.5 & .5 & 7 & $>2$ \\
\hline AL4212 & 150 & $\mathrm{~N}$ & $\mathrm{~N}$ & $\mathrm{~N}$ & 100 & 100 & $\mathrm{~N}$ & $\mathrm{~N}$ & 30 & 10 & $\mathrm{~N}$ & 20 & $\mathrm{~N}$ & $\mathrm{~N}$ & .7 & .2 & 5 & $>2$ \\
\hline AL4214 & 500 & 500 & 400 & $\mathrm{~N}$ & 200 & 500 & $\mathrm{~N}$ & $\mathrm{~N}$ & 20 & 10 & $\mathrm{~N}$ & 30 & $\mathrm{~N}$ & $\mathrm{~N}$ & .5 & .2 & 7 & $>2$ \\
\hline
\end{tabular}


Table 8. Semiquantitative spectrographic analyses for selected elements in panned concentrates of stream-sediment samples, hand-magnet fraction

\begin{tabular}{|c|c|c|c|c|c|c|c|c|c|c|c|c|c|c|c|c|c|}
\hline Sample & \multicolumn{13}{|c|}{$(\mathrm{Ppm})$} & \multicolumn{4}{|c|}{ (Percent) } \\
\hline B2068 & 500 & $\mathrm{~N}$ & $\mathrm{~N}$ & $\mathrm{~N}$ & $\mathrm{~L}$ & $\mathrm{~N}$ & $\mathrm{~N}$ & 20 & $\mathrm{~N}$ & 150 & 30 & $\mathrm{~N}$ & $\mathrm{~N}$ & 30 & .2 & .5 & 1 \\
\hline B2069 & 500 & $\mathrm{~N}$ & $\mathrm{~N}$ & $\mathrm{~N}$ & $\mathrm{~L}$ & $\mathrm{~N}$ & $\mathrm{~N}$ & 30 & $\mathrm{~N}$ & 100 & 30 & $\mathrm{~N}$ & $\mathrm{~N}$ & 50 & .1 & .2 & .7 \\
\hline B2070 & 700 & $\mathrm{~N}$ & $\mathrm{~N}$ & $\mathrm{~N}$ & 50 & $\mathrm{~N}$ & $\mathrm{~N}$ & 20 & $\mathrm{~N}$ & 150 & 50 & $\mathrm{~N}$ & $\mathrm{~N}$ & 50 & .15 & .5 & .5 \\
\hline B2091 & 150 & $\mathrm{~N}$ & $\mathrm{~N}$ & 30 & 700 & $\mathrm{~N}$ & $\mathrm{~N}$ & $\mathrm{~L}$ & $\mathrm{~N}$ & 10 & 30 & 300 & $\mathrm{~N}$ & 1 & .3 & 1.5 & .07 \\
\hline B2111 & 1000 & $\mathrm{~N}$ & $\mathrm{~N}$ & $\mathrm{~N}$ & 50 & $\mathrm{~N}$ & $\mathrm{~N}$ & 50 & $\mathrm{~N}$ & 200 & 70 & $\mathrm{~N}$ & $\mathrm{~N}$ & 50 & .7 & .7 & .7 \\
\hline B2112 & 1000 & $\mathrm{~N}$ & $\mathrm{~N}$ & $\mathrm{~N}$ & 50 & $\mathrm{~N}$ & $\mathrm{~N}$ & 50 & $\mathrm{~N}$ & 200 & 70 & $\mathrm{~N}$ & $\mathrm{~N}$ & 50 & .7 & .7 & 1 \\
\hline B2125 & 700 & $\mathrm{~N}$ & $\mathrm{~N}$ & $\mathrm{~N}$ & 50 & $\mathrm{~N}$ & $\mathrm{~N}$ & 30 & $\mathrm{~N}$ & 100 & 30 & $\mathrm{~N}$ & $\mathrm{~N}$ & 30 & .3 & .15 & .5 \\
\hline B2 126 & 700 & $\mathrm{~N}$ & $\mathrm{~N}$ & $\mathrm{~N}$ & 50 & $\mathrm{~N}$ & $\mathrm{~N}$ & 15 & $\mathrm{~N}$ & 70 & 50 & $\mathrm{~N}$ & $\mathrm{~N}$ & 30 & .1 & .15 & .7 \\
\hline B2145 & 1000 & $\mathrm{~N}$ & $\mathrm{~N}$ & $\mathrm{~N}$ & 50 & $\mathrm{~N}$ & $\mathrm{~N}$ & 30 & $\mathrm{~N}$ & 100 & 70 & $\mathrm{~N}$ & $\mathrm{~N}$ & 30 & .1 & .2 & 1 \\
\hline L2077 & 700 & $\mathrm{~N}$ & $\mathrm{~N}$ & $\mathrm{~N}$ & 50 & $\mathrm{~N}$ & $\mathrm{~N}$ & 20 & $\mathrm{~N}$ & 100 & 30 & $\mathrm{~N}$ & $\mathrm{~N}$ & 50 & .1 & .2 & .5 \\
\hline L2 100 & 1000 & $\mathrm{~N}$ & $\mathrm{~N}$ & $\mathrm{~N}$ & 700 & $\mathrm{~L}$ & $\mathrm{~N}$ & $\mathrm{~L}$ & $\mathrm{~N}$ & 70 & 20 & $\mathrm{~N}$ & $\mathrm{~N}$ & 30 & 1 & 1.5 & .7 \\
\hline L2101 & 700 & $\mathrm{~N}$ & $\mathrm{~N}$ & $\mathrm{~N}$ & 500 & $\mathrm{~N}$ & $\mathrm{~N}$ & 20 & $\mathrm{~N}$ & 150 & 50 & $\mathrm{~N}$ & $\mathrm{~N}$ & 50 & .15 & .3 & .7 \\
\hline L2106 & 500 & $\mathrm{~N}$ & $\mathrm{~N}$ & 700 & 1000 & $\mathrm{~L}$ & $\mathrm{~N}$ & 10 & $\mathrm{~N}$ & 20 & 20 & 300 & $\mathrm{~N}$ & 5 & .7 & 1 & .7 \\
\hline L2108 & 1000 & $\mathrm{~N}$ & $\mathrm{~N}$ & $\mathrm{~N}$ & 70 & $\mathrm{~N}$ & $\mathrm{~N}$ & 70 & $\mathrm{~N}$ & 150 & 30 & $\mathrm{~N}$ & $\mathrm{~N}$ & 50 & .3 & .15 & 1 \\
\hline L2 109 & 10000 & $\mathrm{~N}$ & $\mathrm{~N}$ & 70 & 5000 & $\mathrm{~N}$ & $\mathrm{~N}$ & 70 & $\mathrm{~N}$ & 50 & 200 & $\mathrm{~N}$ & $\mathrm{~N}$ & 15 & .7 & .1 & 1.5 \\
\hline
\end{tabular}

Table 9. Semiquantitative spectrographic analyses for selected elements in panned concentrates of stream-sediment samples, fraction magnetic at 2.0 amperes

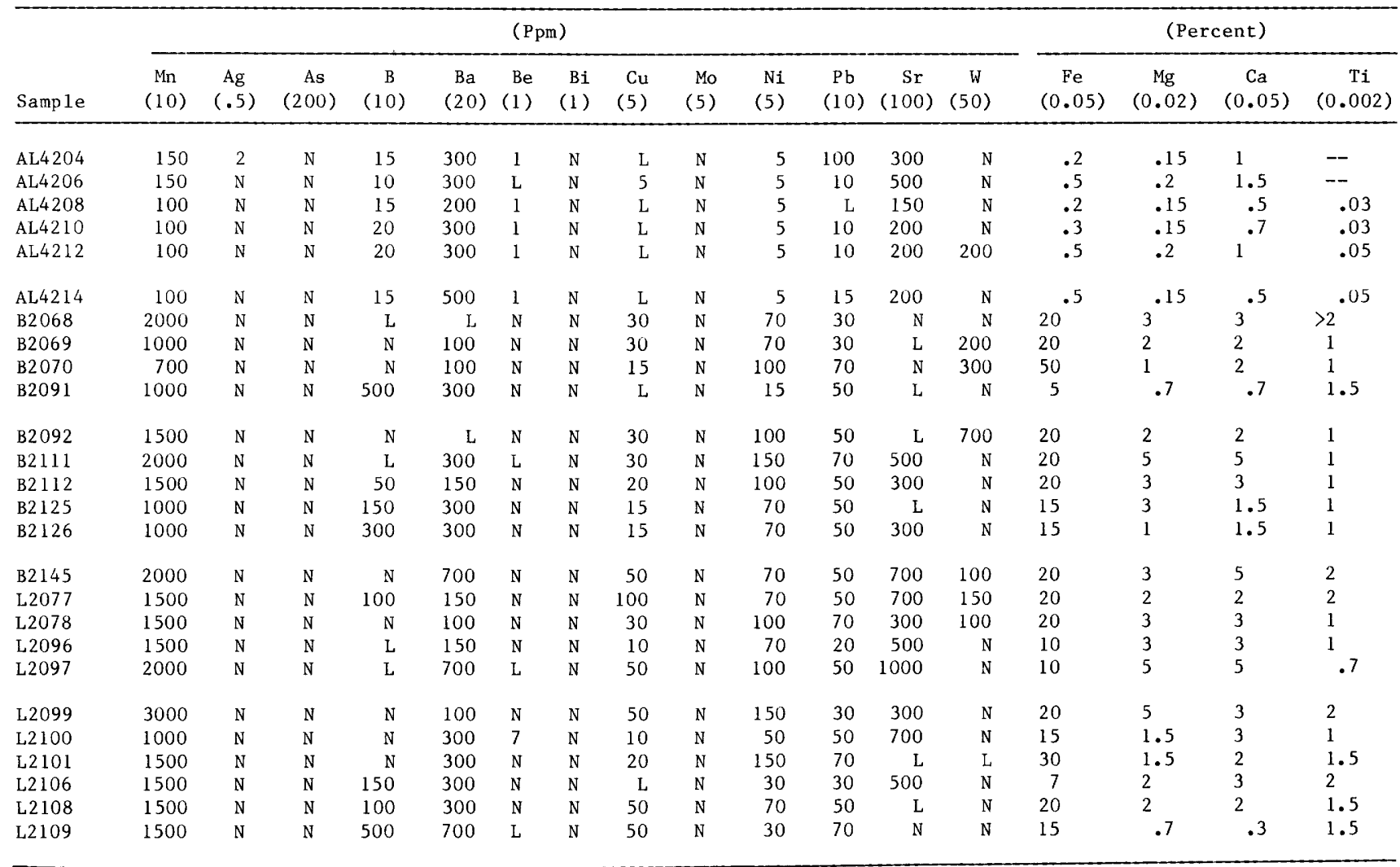


Table 10. Semiquantitative spectrographic analyses for selected elements in panned concentrates of stream-sediment samples, nonmagnetic fraction

\begin{tabular}{|c|c|c|c|c|c|c|c|c|c|c|c|c|c|c|c|c|c|}
\hline \multirow[b]{2}{*}{ Samp le } & \multicolumn{13}{|c|}{$(\mathrm{Ppm})$} & \multicolumn{4}{|c|}{ (Percent) } \\
\hline & $\begin{array}{c}\mathrm{Mn} \\
(10)\end{array}$ & $\begin{array}{c}\mathrm{Ag} \\
(.5)\end{array}$ & $\begin{array}{l}\text { As } \\
(200)\end{array}$ & $\begin{array}{c}\text { B } \\
(10)\end{array}$ & $\begin{array}{l}\mathrm{Ba} \\
(20)\end{array}$ & $\begin{array}{l}\mathrm{Be} \\
(1)\end{array}$ & $\begin{array}{l}B i \\
(1)\end{array}$ & $\begin{array}{l}\mathrm{Cu} \\
(5)\end{array}$ & $\begin{array}{l}\text { Mo } \\
\text { (5) }\end{array}$ & $\begin{array}{l}\mathrm{Ni} \\
(5)\end{array}$ & $\begin{array}{c}\mathrm{Pb} \\
(10)\end{array}$ & $\begin{array}{c}\mathrm{Sr} \\
(100)\end{array}$ & $\begin{array}{c}W \\
(50)\end{array}$ & $\begin{array}{c}\mathrm{Fe} \\
(0.05)\end{array}$ & $\begin{array}{c}\mathrm{Mg} \\
(0.02)\end{array}$ & $\begin{array}{c}\mathrm{Ca} \\
(0.05)\end{array}$ & $\begin{array}{c}\mathrm{Ti} \\
(0.002)\end{array}$ \\
\hline B2068 ${ }^{1}$ & 20 & $\mathrm{~N}$ & $\mathrm{~N}$ & $\mathrm{~N}$ & 300 & $\mathrm{~N}$ & $\mathrm{~N}$ & 10 & $\mathrm{~N}$ & $\mathrm{~L}$ & 20 & $\mathrm{~N}$ & $\mathrm{~N}$ & .3 & .05 & .7 & .07 \\
\hline B2069 & 50 & $\mathrm{~N}$ & $\mathrm{~N}$ & L & 5000 & $\mathrm{~N}$ & $\mathrm{~N}$ & $\mathrm{~L}$ & $\mathrm{~N}$ & $\mathrm{~N}$ & 30 & $\mathrm{~N}$ & $\mathrm{~N}$ & .7 & .07 & .7 & .15 \\
\hline B2070 & 20 & $\mathrm{~N}$ & $\mathrm{~N}$ & $\mathrm{~N}$ & 200 & $\mathrm{~L}$ & $\mathrm{~N}$ & $\mathrm{~L}$ & 70 & $\mathrm{~L}$ & 30 & $\mathrm{~L}$ & 700 & .3 & .05 & 1.5 & .2 \\
\hline B2091 & 30 & $\mathrm{~N}$ & $\mathrm{~N}$ & $\mathrm{~N}$ & 300 & $\mathrm{~N}$ & $\mathrm{~N}$ & $\mathrm{~L}$ & $\mathrm{~N}$ & $\mathrm{~L}$ & 30 & $N$ & $\mathrm{~N}$ & .5 & .07 & .2 & .07 \\
\hline В2092 & 50 & $\mathrm{~N}$ & $\mathrm{~N}$ & $\mathrm{~N}$ & 500 & $\mathrm{~N}$ & 2000 & 10 & $\mathrm{~N}$ & 10 & 150 & 300 & $\mathrm{~N}$ & 1 & .15 & 2 & .2 \\
\hline B2111 & 70 & $\mathrm{~N}$ & $\mathrm{~N}$ & 20 & 700 & $\mathrm{~N}$ & $\mathrm{~N}$ & $\mathrm{~L}$ & $\mathrm{~N}$ & $\mathrm{~N}$ & 50 & 700 & $\mathrm{~N}$ & .5 & .1 & 2 & .15 \\
\hline B2 112 & 20 & $\mathrm{~N}$ & $\mathrm{~N}$ & $\mathrm{~L}$ & 300 & $\mathrm{~N}$ & $\mathrm{~N}$ & $\mathrm{~L}$ & $\mathrm{~N}$ & $\mathrm{~L}$ & 30 & 300 & $\mathrm{~N}$ & .5 & .07 & .7 & .1 \\
\hline B2125 & 50 & $\mathrm{~N}$ & $\mathrm{~N}$ & $\mathrm{~N}$ & 300 & $\mathrm{~N}$ & $\mathrm{~N}$ & $\mathrm{~L}$ & $\mathrm{~N}$ & L & 30 & $\mathrm{~N}$ & $\mathrm{~N}$ & .7 & .1 & .5 & .07 \\
\hline B2126 & 50 & $\mathrm{~N}$ & $\mathrm{~N}$ & $\mathrm{~N}$ & 500 & $\mathrm{~N}$ & $\mathrm{~N}$ & $\mathrm{~L}$ & $\mathrm{~N}$ & $\mathrm{~N}$ & $\mathrm{~L}$ & $\mathrm{~N}$ & $\mathrm{~N}$ & .7 & .1 & .5 & .07 \\
\hline B2145 & 150 & $\mathrm{~N}$ & $\mathrm{~N}$ & 20 & 1000 & $\mathrm{~N}$ & 500 & 10 & $\mathrm{~N}$ & $\mathrm{~L}$ & 50 & 1000 & $\mathrm{~N}$ & .7 & .15 & 3 & .1 \\
\hline $\mathrm{L} 2077^{2}$ & 50 & 50 & $\mathrm{~N}$ & $\mathrm{~N}$ & 500 & $\mathrm{~N}$ & 1500 & $\mathrm{~L}$ & 20 & $\mathrm{~L}$ & 20 & L & 150 & .5 & .07 & 1 & .07 \\
\hline L2078 & 50 & $\mathrm{~N}$ & $\mathrm{~N}$ & $\mathrm{~N}$ & 300 & $\mathrm{~N}$ & 700 & $\mathrm{~L}$ & 30 & $\mathrm{~N}$ & 20 & 300 & 300 & .5 & .07 & 1.5 & .07 \\
\hline L2096 & 30 & $\mathrm{~N}$ & $\mathrm{~N}$ & $\mathrm{~N}$ & 300 & $\mathrm{~N}$ & $\mathrm{~N}$ & $\mathrm{~L}$ & $\mathrm{~N}$ & $\mathrm{~N}$ & 20 & L & $\mathrm{N}$ & .2 & .07 & .7 & .07 \\
\hline L2097 & 100 & $\mathrm{~N}$ & $\mathrm{~N}$ & $\mathrm{~N}$ & 1000 & $\mathrm{~N}$ & $\mathrm{~N}$ & 20 & $\mathrm{~N}$ & $\mathrm{~N}$ & 50 & 1000 & $\mathrm{~N}$ & 1 & .15 & 2 & .07 \\
\hline L2099 & 30 & $\mathrm{~N}$ & $\mathrm{~N}$ & $\mathrm{~N}$ & 500 & $\mathrm{~N}$ & $\mathrm{~N}$ & L & $\mathrm{N}$ & $\mathrm{L}$ & 30 & N & $\mathrm{N}$ & .7 & .1 & .7 & .07 \\
\hline L2 100 & 20 & $\mathrm{~N}$ & $\mathrm{~N}$ & $\mathrm{~N}$ & 700 & $\mathrm{~L}$ & $\mathrm{~N}$ & $\mathrm{~L}$ & $\mathrm{~N}$ & $\mathrm{~L}$ & 20 & 500 & $\mathrm{~N}$ & .7 & .07 & .7 & .1 \\
\hline L2101 & 50 & $\mathrm{~N}$ & $\mathrm{~N}$ & $\mathrm{~L}$ & $>10000$ & $\mathrm{~N}$ & $\mathrm{~N}$ & 20 & $\mathrm{~N}$ & $\mathrm{~N}$ & 50 & 700 & $\mathrm{~N}$ & .5 & .07 & .7 & .2 \\
\hline L2106 & 20 & $\mathrm{~N}$ & $\mathrm{~N}$ & $\mathrm{~N}$ & 300 & $\mathrm{~N}$ & $\mathrm{~N}$ & $\mathrm{~N}$ & $\mathrm{~N}$ & $\mathrm{~L}$ & L & $\mathrm{N}$ & $\mathrm{N}$ & .2 & .07 & .3 & .1 \\
\hline L2108 & 50 & $\mathrm{~N}$ & $\mathrm{~N}$ & $\mathrm{~N}$ & 500 & $\mathrm{~N}$ & $\mathrm{~N}$ & 10 & $\mathrm{~N}$ & 10 & 20 & $\mathrm{~N}$ & $\mathrm{~N}$ & 1 & .15 & .7 & .2 \\
\hline L2109 & 50 & $\mathrm{~N}$ & $\mathrm{~N}$ & $\mathrm{~N}$ & 200 & $\mathrm{~N}$ & $\mathrm{~N}$ & $\mathrm{~L}$ & $\mathrm{~N}$ & $\mathrm{~N}$ & 20 & $\mathrm{~N}$ & $\mathrm{~N}$ & .5 & .1 & .15 & .15 \\
\hline
\end{tabular}

\footnotetext{
1 Also contains $100 \mathrm{ppm} \mathrm{Au}$.

$2 \mathrm{Also}$ contains $50 \mathrm{ppm} \mathrm{Au}$.
}

Table 11. Semiquantitative spectrographic analyses for selected elements in panned concentrates of vein samples

\begin{tabular}{|c|c|c|c|c|c|c|c|c|c|c|c|c|c|c|c|c|c|}
\hline \multirow[b]{2}{*}{ Sample } & \multicolumn{13}{|c|}{$(\mathrm{Ppm})$} & \multicolumn{4}{|c|}{ (Percent) } \\
\hline & $\begin{array}{c}\text { Mn } \\
(10)\end{array}$ & $\begin{array}{c}\mathrm{Ag} \\
(.5)\end{array}$ & $\begin{array}{l}\text { As } \\
(200)\end{array}$ & $\begin{array}{l}\text { B } \\
(10)\end{array}$ & $\begin{array}{l}\mathrm{Ba} \\
(20)\end{array}$ & $\begin{array}{l}\mathrm{Be} \\
(1)\end{array}$ & $\begin{array}{l}\mathrm{Bi} \\
\text { (1) }\end{array}$ & $\begin{array}{l}\mathrm{Cu} \\
(5)\end{array}$ & $\begin{array}{l}\text { Mo } \\
(5)\end{array}$ & $\begin{array}{l}\mathrm{Ni} \\
(5)\end{array}$ & $\begin{array}{c}\mathrm{Pb} \\
(10)\end{array}$ & $\begin{array}{l}\mathrm{Sr} \\
(100)\end{array}$ & $\begin{array}{l}W \\
(50)\end{array}$ & $\begin{array}{c}\mathrm{Fe} \\
(0.05)\end{array}$ & $\begin{array}{c}\mathrm{Mg} \\
(0.02)\end{array}$ & $\begin{array}{c}\mathrm{Ca} \\
(0.05)\end{array}$ & $\begin{array}{c}\mathrm{Ti} \\
(0.002)\end{array}$ \\
\hline B2046 & 1500 & $\mathrm{~N}$ & $\mathrm{~N}$ & $\mathrm{~N}$ & 70 & $\mathrm{~N}$ & $\mathrm{~N}$ & 70 & 30 & 150 & 30 & $\mathrm{~N}$ & 300 & 30 & .07 & $\mathrm{~L}$ & .007 \\
\hline B2135 & 1500 & $\mathrm{~N}$ & $\mathrm{~N}$ & 500 & 700 & $\mathrm{~L}$ & $\mathrm{~N}$ & 50 & $\mathrm{~L}$ & 100 & 100 & $\mathrm{~N}$ & $\mathrm{~N}$ & 15 & .15 & .5 & .5 \\
\hline B2 $144^{1}$ & 1000 & 30 & $\mathrm{~N}$ & $\mathrm{~N}$ & $>10000$ & $\mathrm{~N}$ & $\mathrm{~N}$ & 50 & $\mathrm{~N}$ & 70 & 50 & 10000 & $\mathrm{~N}$ & 20 & .07 & .1 & .2 \\
\hline L2019 & 3000 & $\mathrm{~L}$ & $\mathrm{~N}$ & $\mathrm{~N}$ & $>10000$ & $\mathrm{~N}$ & $\mathrm{~N}$ & 150 & N & 150 & 50 & $\mathrm{~N}$ & $\mathrm{~N}$ & 50 & .15 & $\mathrm{~L}$ & $\mathrm{~L}$ \\
\hline L2035 & 500 & 30 & $\mathrm{~N}$ & $\mathrm{~N}$ & $>10000$ & N & $\mathrm{N}$ & 200 & $\mathrm{~N}$ & 100 & 2000 & 3000 & L & 20 & $\mathrm{~L}$ & $\mathrm{~L}$ & .015 \\
\hline L2053 & 1500 & $\mathrm{~L}$ & $\mathrm{~N}$ & $\mathrm{~N}$ & 1000 & $\mathrm{~N}$ & $\mathrm{~N}$ & 100 & $\mathrm{~L}$ & 200 & 70 & $\mathrm{~N}$ & $\mathrm{~N}$ & 50 & .07 & $\mathrm{~L}$ & .2 \\
\hline L2074 & 1000 & $\mathrm{~N}$ & $\mathrm{~N}$ & 200 & 1500 & $\mathrm{~N}$ & $\mathrm{~N}$ & 50 & $\mathrm{~N}$ & 70 & 30 & $\mathrm{~N}$ & $\mathrm{~N}$ & 20 & .07 & .1 & .1 \\
\hline L2107 & 500 & $\mathrm{~N}$ & $\mathrm{~N}$ & $\mathrm{~N}$ & $>10000$ & $\mathrm{~N}$ & $\mathrm{~N}$ & 30 & $\mathrm{~N}$ & 30 & $\mathrm{~L}$ & 10000 & $\mathrm{~N}$ & 10 & $\mathrm{~L}$ & $\mathrm{~L}$ & $\mathrm{~N}$ \\
\hline L2111 & 2000 & $\mathrm{~N}$ & $\mathrm{~N}$ & $\mathrm{~N}$ & 1000 & $\mathrm{~N}$ & $\mathrm{~N}$ & 150 & $\mathrm{~N}$ & 70 & 50 & $\mathrm{~N}$ & $\mathrm{~N}$ & 20 & .07 & $\mathrm{~L}$ & $\mathrm{~N}$ \\
\hline L2112 & 2000 & 7 & $\mathrm{~N}$ & $\mathrm{~N}$ & 700 & $\mathrm{~N}$ & $\mathrm{~N}$ & 500 & $\mathrm{~N}$ & 50 & 30 & $\mathrm{~N}$ & $\mathrm{~N}$ & 30 & .07 & $\mathrm{~L}$ & $\mathrm{~N}$ \\
\hline
\end{tabular}

${ }^{1}$ Also contains $70 \mathrm{ppm} \mathrm{Au}$.

The possible concentric zoning patterns of elements around the pervasively altered zone suggest mineral deposition around a hydrothermal source (the Cretaceous or Tertiary granodiorite plug). The possible northwestsoutheast trends of high geochemical analyses correspond to the joint trends in the Miners Gulch stock. Joints thus may have provided channelways for mineralizing solutions during vein formation. The concentric and linear trends do not appear to be closely related, because different element associations characterize each pattern. The two patterns may have developed at different times during the history of the Miners Gulch stock.

\section{Analysis of Gold Samples}

\section{Character of Gold}

Individual gold grains obtained from the study area showed great variation in size, shape, and surface 


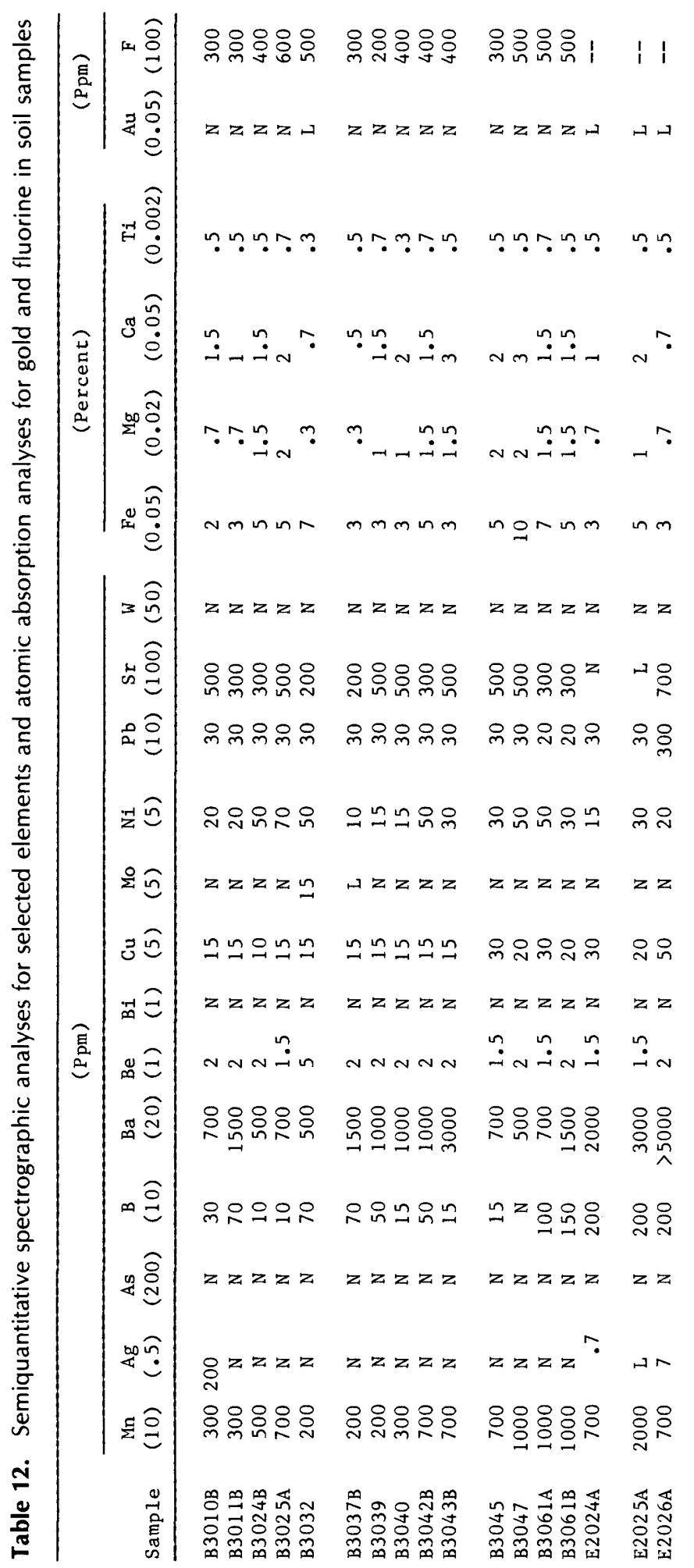

features. Rarely, the gold grains contained attached quartz (fig. 16), mineral inclusions (including galena and various unidentified bismuth-tellurium, cobalt-nickelsulfur, iron-manganese-magnesium, and iron) minerals. Numerous grains displayed irregular surface textures, discolored rims, and cavities.

The size of the recovered grains, measured along the longest axis, ranged from less than $40 \mu \mathrm{m}$ to $2 \mathrm{~mm}$. The average size of grains used for microprobe study was about $200 \mu \mathrm{m}$.

Shapes of gold grains are varied and include rounded nuggets (fig. 17); elongate, angular pieces showing cubic mineral casts; and wire forms ranging from wormlike to very slender, delicate types. Rounded gold nuggets with irregular outlines were the most abundant form. Wires were collected from alluvium (fig. 18) and from one vein (fig. 19), although rounded grains were predominant in alluvium.

\section{Electron Microprobe Study}

One hundred and twenty-one gold grains from 24 localities were analyzed by electron microprobe using standard procedures to determine the fineness of the gold (fig. 20). Throughout this paper the term "fineness" indicates true fineness, as discussed by Fisher (1945). True fineness values are gold and silver contents recalculated to total 1,000 , thus eliminating the other metal impurities from the calculation. That is, the fineness values used here represent only the gold content of the alloy.

Grains picked for microprobe analysis were set in mounts and polished to provide clean cross sections. Each mount was photographed at magnifications ranging from X110 to X430. Locations of points chosen for microprobe analysis were noted on Polaroid photographs of the grains.

For most gold grains, three points were analyzedtwo on the grain edge and one in the grain center. More than three points per grain were analyzed when the grain appeared to contain large variations in the range of gold fineness. Analyses for which the total of $\mathrm{Au}+\mathrm{Ag}$ was less than 90 weight percent were rejected. A total of 349 point measurements was accepted.

Fineness values of heterogeneous grains (16 percent of the microprobed grains) had high standard deviations (between 14.0 and 185.3), and some of these grains also showed varying reflectivity and color. Step-scans were performed on several of the heterogeneous grains. On step-scans, 10 points were analyzed at equally spaced increments, (ranging from 0.004 to $0.016 \mathrm{~mm}$, depending on magnification) across the surface of a grain. Figure 21 shows results of two step-scans made on grains in which the centers contained gold of lower fineness than the edges. 
Table 13. Positive linear correlation coefficients for pairs of elements from geochemical analyses of rock samples (after log transformations)

[All correlations are significant at the $95 \%$ confidence level]

\begin{tabular}{lccc}
\hline $\begin{array}{l}\text { Element } \\
\text { pair }\end{array}$ & $\begin{array}{l}\text { Correlation } \\
\text { coefficient }\end{array}$ & $\begin{array}{l}\text { Variability } \\
\text { explained } \\
\text { (percent) }\end{array}$ & $\begin{array}{l}\text { No. of sample } \\
\text { pairs in each } \\
\text { coefficent }\end{array}$ \\
\hline $\mathrm{Sb}-\mathrm{Cu}$ & 0.618 & 38.2 & 40 \\
$\mathrm{Sb}-\mathrm{As}$ & 0.521 & 27.1 & 46 \\
$\mathrm{Sb}-\mathrm{Hg}$ & 0.510 & 26.0 & 44 \\
$\mathrm{As}-\mathrm{Cu}$ & 0.506 & 25.6 & 43 \\
$\mathrm{Cu}-\mathrm{Hg}$ & 0.475 & 22.6 & 40 \\
$\mathrm{As}-\mathrm{Hg}$ & 0.374 & 14.0 & 48 \\
$\mathrm{Fe}-\mathrm{Hg}$ & 0.414 & 17.1 & 53 \\
$\mathrm{Hg}-\mathrm{Zn}$ & 0.403 & 16.2 & 49 \\
$\mathrm{Ba}-\mathrm{Hg}$ & 0.343 & 11.8 & 41 \\
\hline
\end{tabular}

\footnotetext{
${ }^{1} \mathrm{Cu}, \mathrm{Fe}$, and $\mathrm{Ba}$ were analyzed by semiquantitative spectrographic analysis. As, $\mathrm{Hg}, \mathrm{Sb}$, and $\mathrm{Zn}$ were analyzed by atomic absorption technique.
}

Table 14. Linear correlation coefficients between gold and 24 selected elements [Data is from 51 analyses of rock samples containing chemically detectable gold. Dashes indicate correlations not significant at $95 \%$ confidence level]

\begin{tabular}{|c|c|c|c|c|}
\hline Element & $\begin{array}{l}\text { Correlation } \\
\text { coefficient }\end{array}$ & $\begin{array}{l}\text { Variance explained } \\
\text { (percent) }\end{array}$ & $\begin{array}{l}\text { Number of sample pairs } \\
\text { in each coefficent }\end{array}$ & $\begin{array}{l}\text { Confidence } \\
\text { level } \\
\text { (percent) }\end{array}$ \\
\hline $\mathrm{Mg}$ & -0.202 & 4.08 & 42 & --- \\
\hline $\mathrm{Ca}$ & -0.261 & 6.81 & 22 & -- \\
\hline B & -0.227 & 5.15 & 21 & -- \\
\hline $\mathrm{Ni}$ & 0.146 & 2.13 & 51 & -- \\
\hline $\mathrm{Sr}$ & -0.796 & 63.36 & 11 & $>95$ \\
\hline $\mathrm{Fe}$ & 0.293 & 8.59 & 40 & --- \\
\hline $\mathrm{Mn}$ & -0.280 & 7.84 & 51 & -- \\
\hline $\mathrm{Ag}$ & 0.016 & 0.03 & 24 & $\ldots$ \\
\hline $\mathrm{As}^{1}$ & 0.475 & 22.56 & 22 & $>95$ \\
\hline $\mathrm{Ba}$ & -0.027 & 0.07 & 39 & -- \\
\hline $\mathrm{Be}$ & 0.241 & 5.81 & 18 & --- \\
\hline $\mathrm{Bi}^{1}$ & -0.312 & 9.73 & 10 & $\ldots$ \\
\hline $\mathrm{Cd}^{1}$ & 0.011 & 0.01 & 21 & -- \\
\hline $\mathrm{Cu}$ & 0.022 & 0.05 & 47 & --- \\
\hline Mo & 0.194 & 3.76 & 18 & -- \\
\hline $\mathrm{Pb}$ & 0.190 & 3.61 & 35 & -- \\
\hline $\mathrm{Sb}^{1}$ & 0.459 & 21.07 & 17 & -- \\
\hline W & -0.167 & 2.79 & 6 & -- \\
\hline $\mathrm{Zn}^{1}$ & 0.009 & 0.00 & 21 & -- \\
\hline $\mathrm{Hg}^{1}$ & 0.052 & 0.27 & 18 & $-\ldots$ \\
\hline
\end{tabular}

$1_{\text {Elements analyzed by atomic absorption technique. All other elements }}$ analyzed by semiquantitative spectrography.

\section{Discussion of Characteristics of Gold Grains}

Two populations of gold fineness are suggested from figure 20: a high fineness population (900-1000 fine) and a low fineness population (less than 900 fine).
Numbers of grains of each sample type in the two populations are listed in table 15. As shown in table 15, gold from veins has low fineness and that from terraces has high fineness. About 60 percent of the gold from alluvium has high fineness and $\mathbf{4 0}$ percent has low fineness. Both 


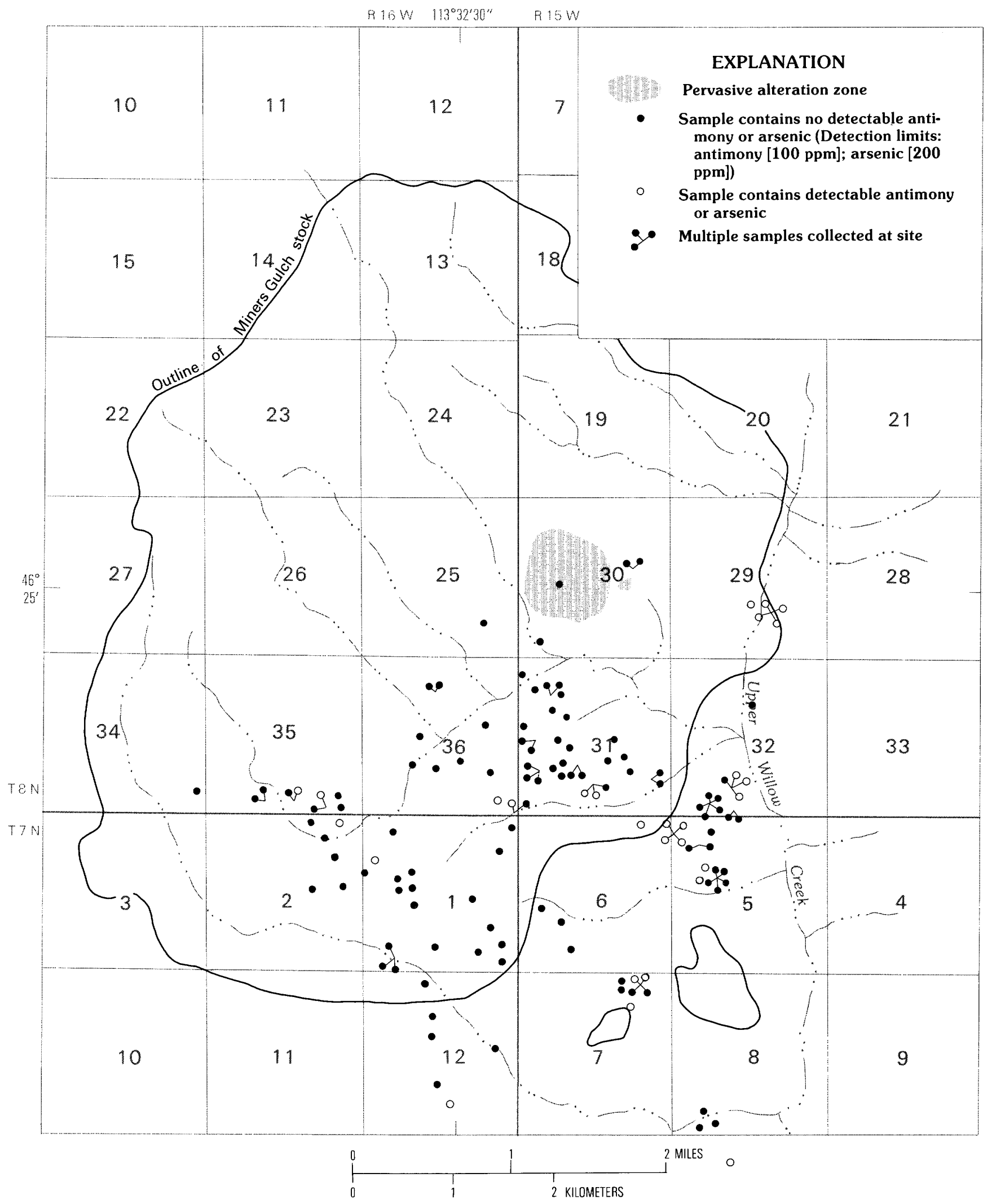

Figure 11. Geochemical distribution of antimony and arsenic from 133 rock samples (see table 5). 


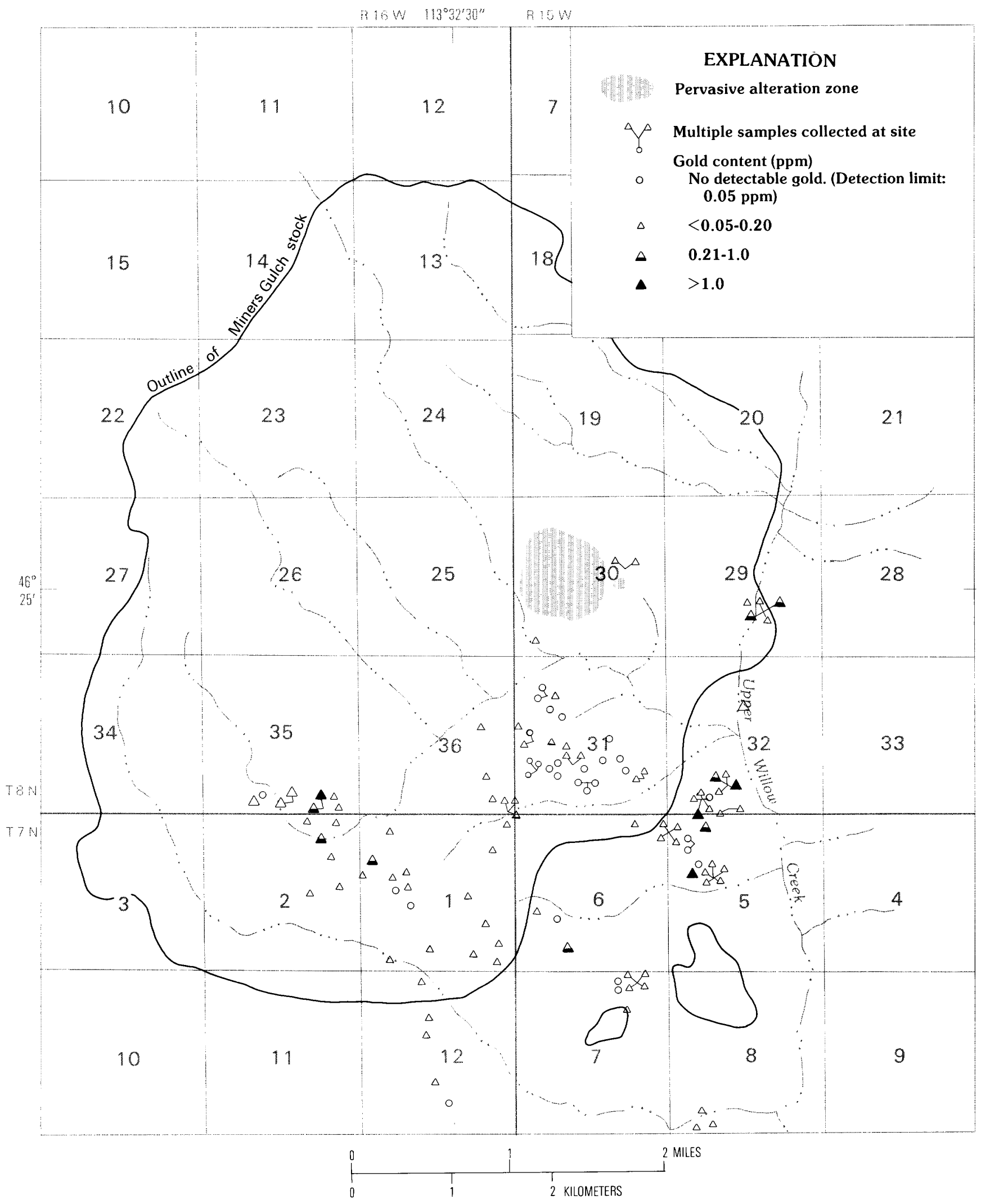

Figure 12. Geochemical distribution of gold from 133 rock samples (see table 4). 


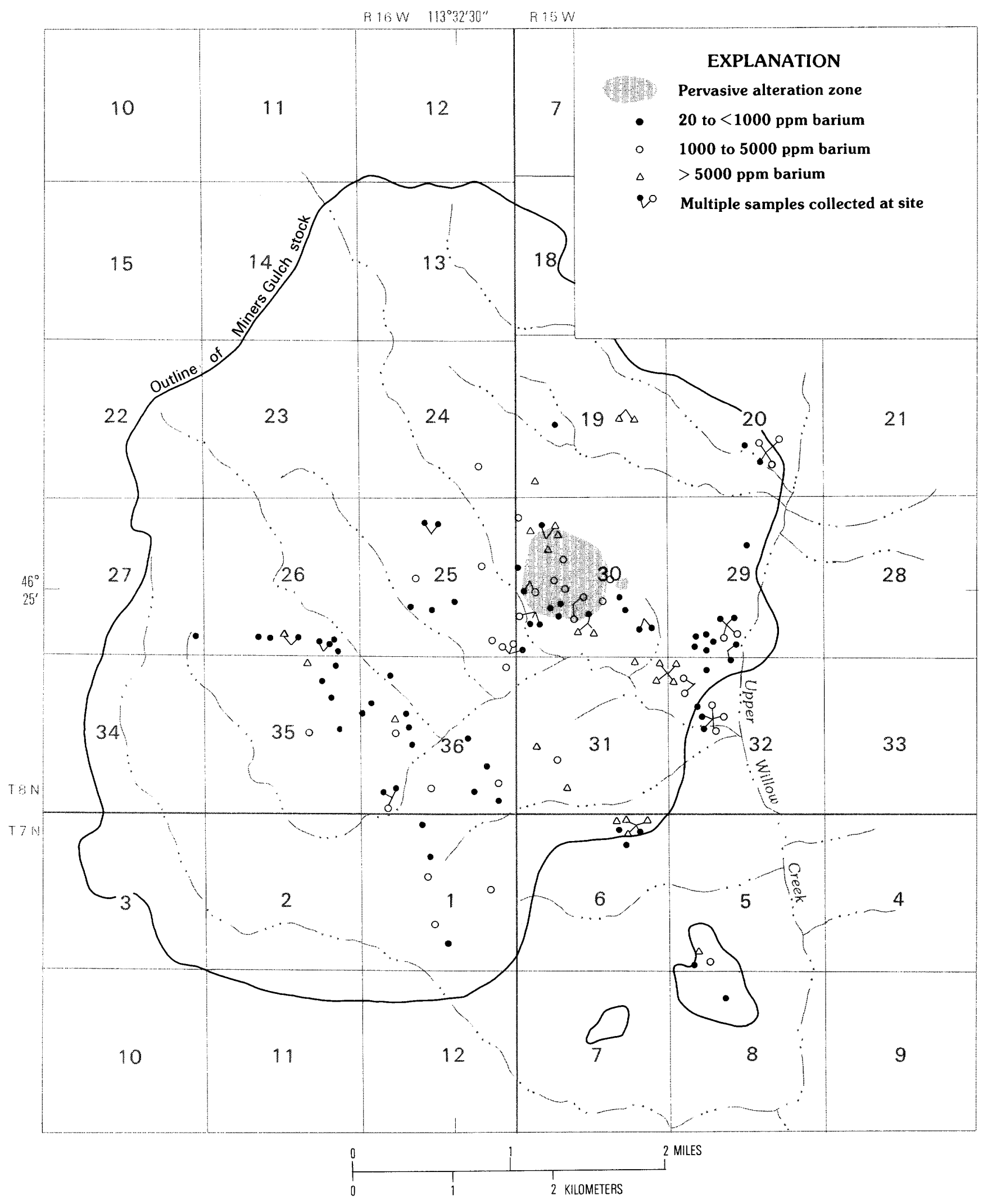

Figure 13. Geochemical distribution of barium from 133 rock samples (see table 4). 


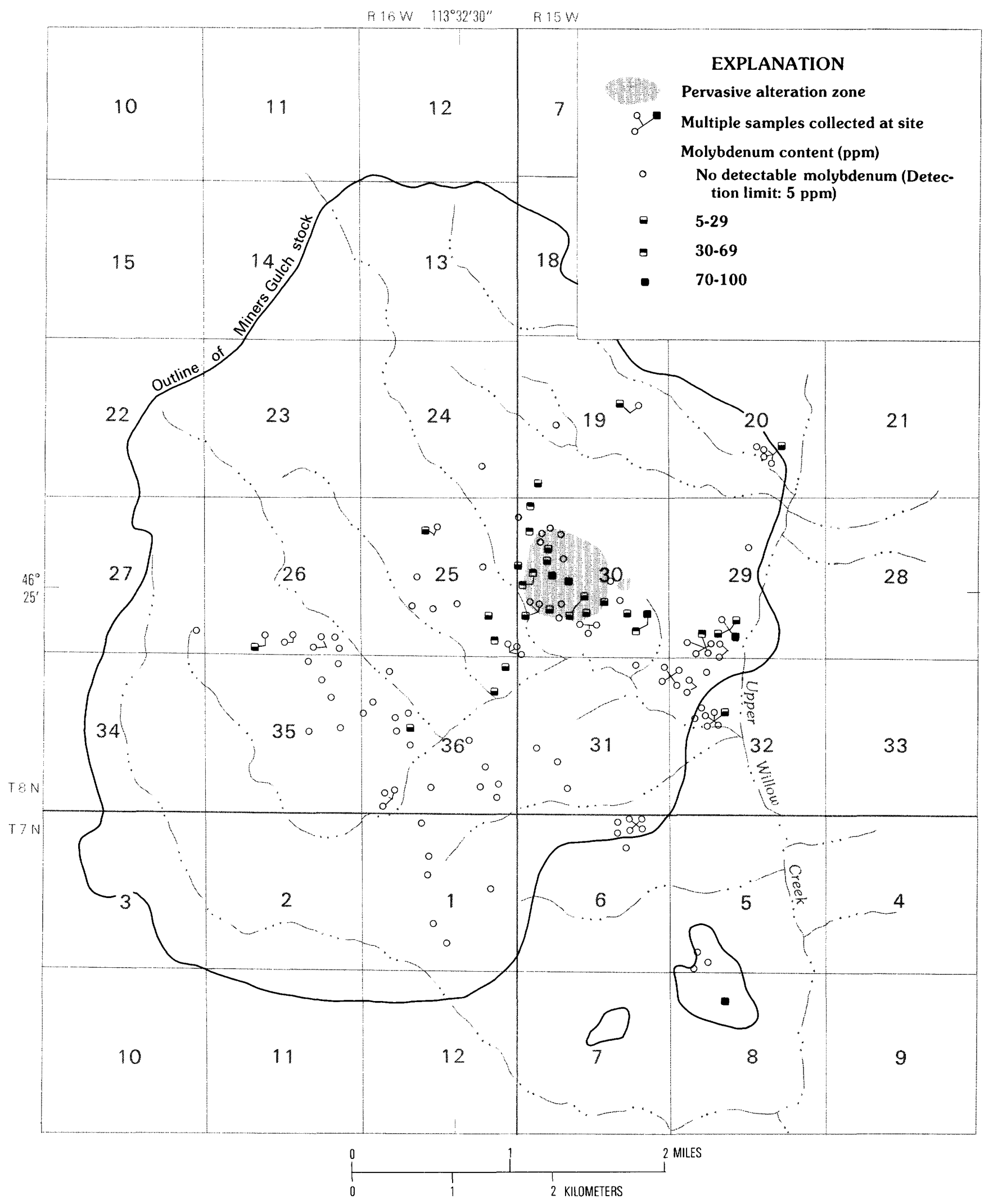

Figure 14. Geochemical distribution of molybdenum from 133 rock samples (see table 4). 


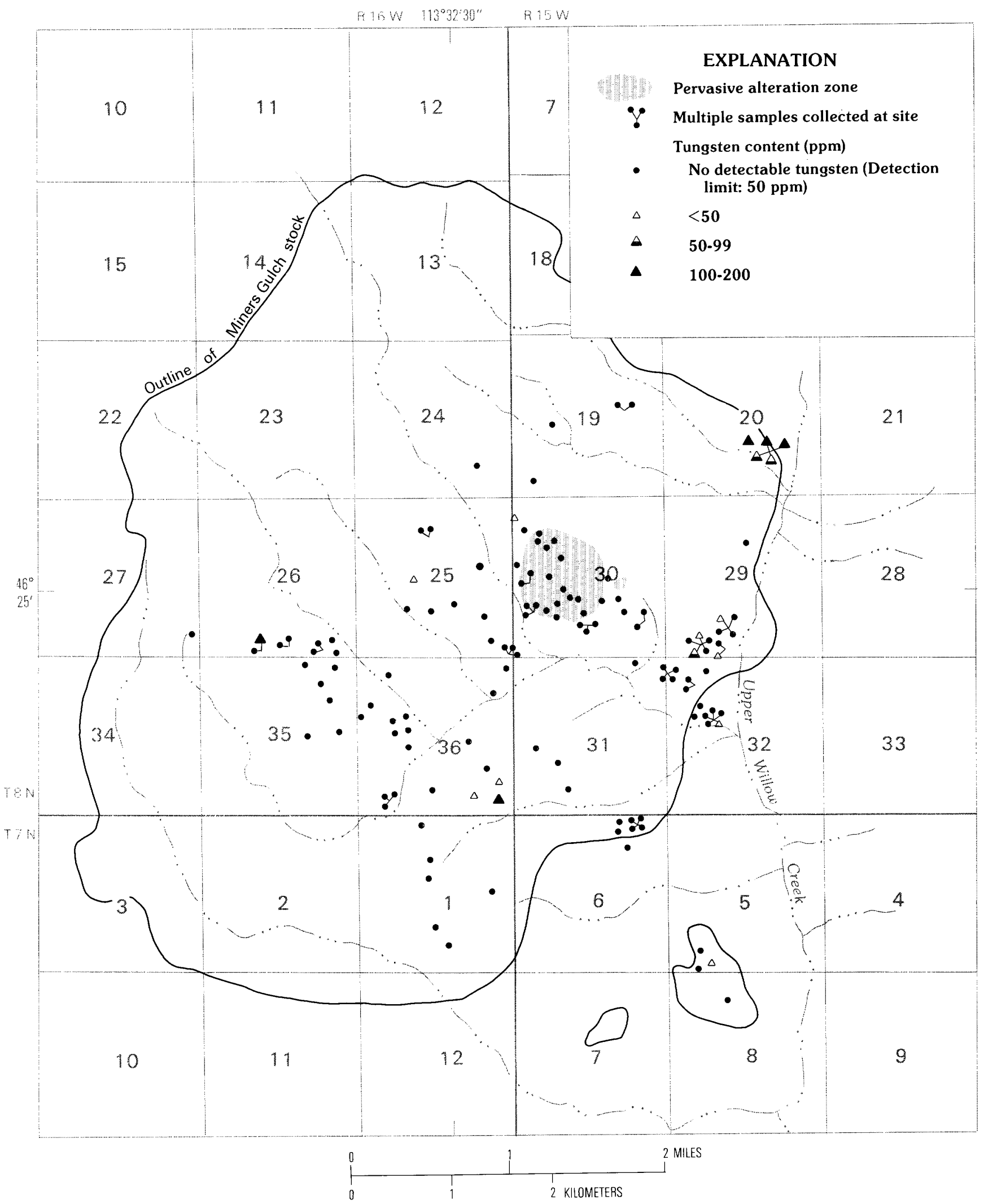

Figure 15. Geochemical distribution of tungsten from 133 rock samples (for data, see table 4). 


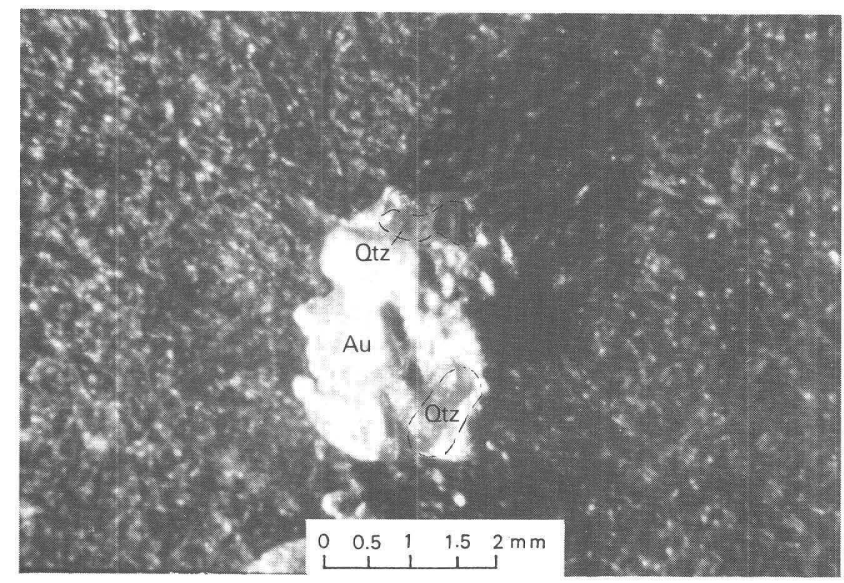

Figure 16. Gold (Au) with attached quartz crystal (Qtz) from alluvium in gulch south of Sawpit Gulch (sample B2091). Magnification: $12.8 \mathrm{X}$.

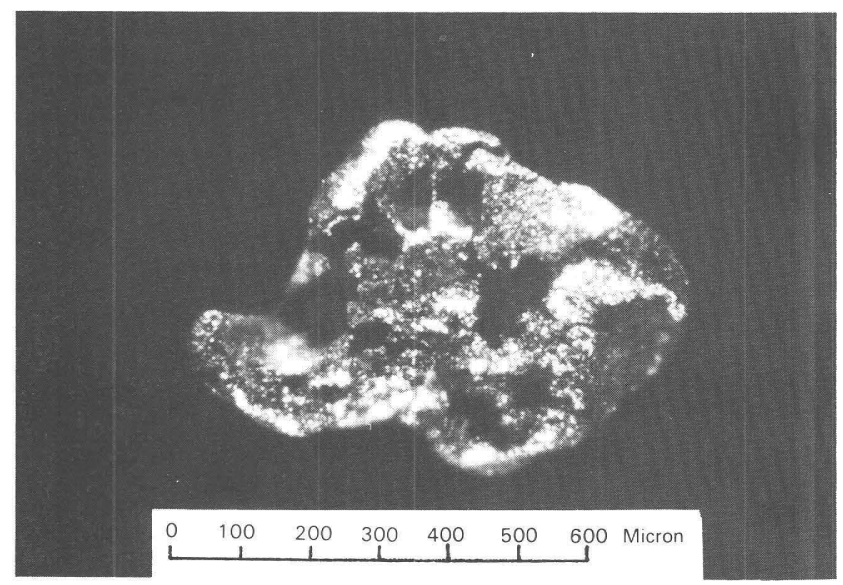

Figure 17. Rounded gold nugget from alluvium in Homestake Gulch (sample B2070).

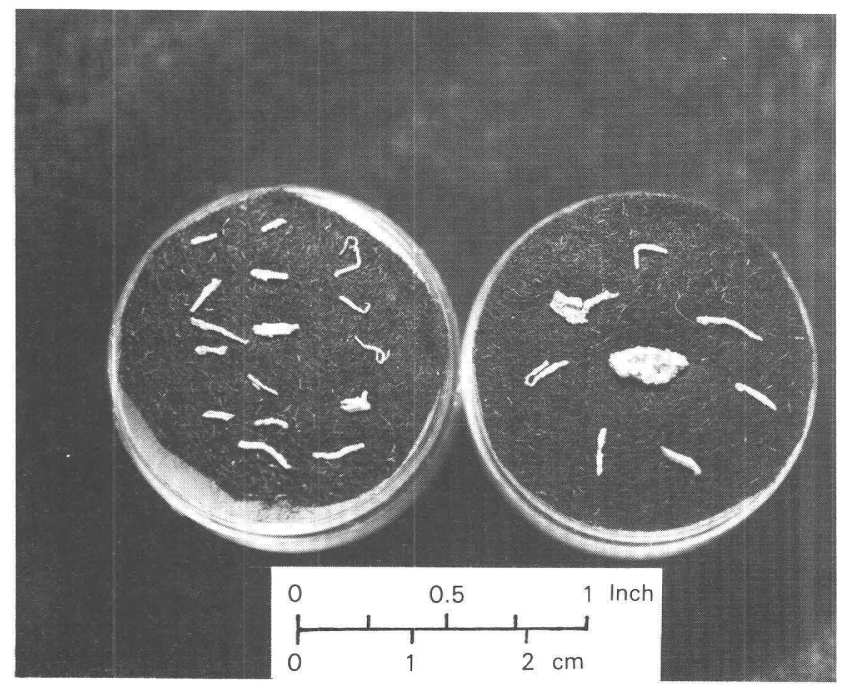

Figure 18. Wire gold and angular nuggets from placer mine in Upper Sawpit Gulch. Mined from placer deposits that are alluvial and colluvial. Gold-bearing gravels occur as thin (3-12 in.) layers between massive grus layers.

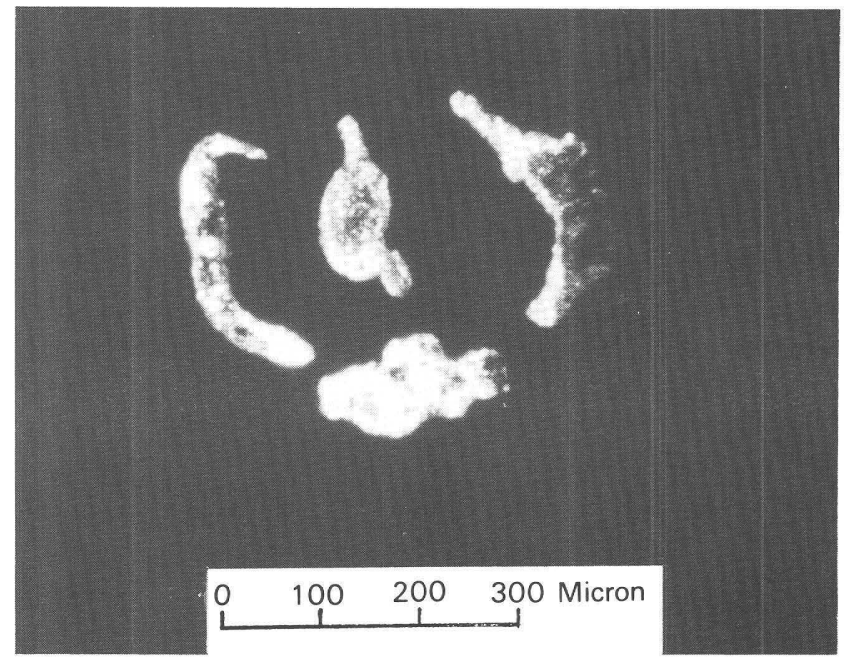

Figure 19. Wire gold from vein south of Sawpit Gulch. Gold was separated from vein by grinding and panning. Microprobe analyses of points on two grains from this sample (L2107) averaged 862 and 866 fine, respectively.

low- and high-fineness gold is present in vein cobbles found in placer tailings, but contamination by detrital gold in the adhered mud is possible. Heterogeneous gold grains belong to either the high- and the low-fineness populations (fig. 20).

The processes that caused the heterogeneous fineness in some of the grains could not be determined from the data available. However, Desborough (1970) presented step-scan data on heterogeneous grains that showed rates of change of fineness between higher fineness rims and lower fineness interiors similar to those shown on figure 21 . He concluded that the high steepness of the rim-to-interior gradient indicates that the process affecting the rims is operative at low temperatures (probably less than $100{ }^{\circ} \mathrm{C}$ ). Desborough favored selective dissolution of silver in the placer environment or in the oxidizing zone of primary mineral deposits as the process. Other heterogeneous grains from the study area contained lower fineness rims and higher fineness interiors. Because selective dissolution of silver in grain interiors is unlikely, primary zoning was probably responsible for this type of heterogeneity. Grains that showed this type of zoning all belonged to the low-fineness population.

\section{Molybdenum Anomaly}

A molybdenum anomaly was identified by geochemical sampling within or adjacent to the Cretaceous or Tertiary porphyritic granodiorite plug (map unit TKpg) in the W $1 / 2$ sec. 30 , T. 8 N., R. 15 W. The anomaly coincides with a zone of strong sericitic alteration of the granodiorite plug and the granodiorite of 


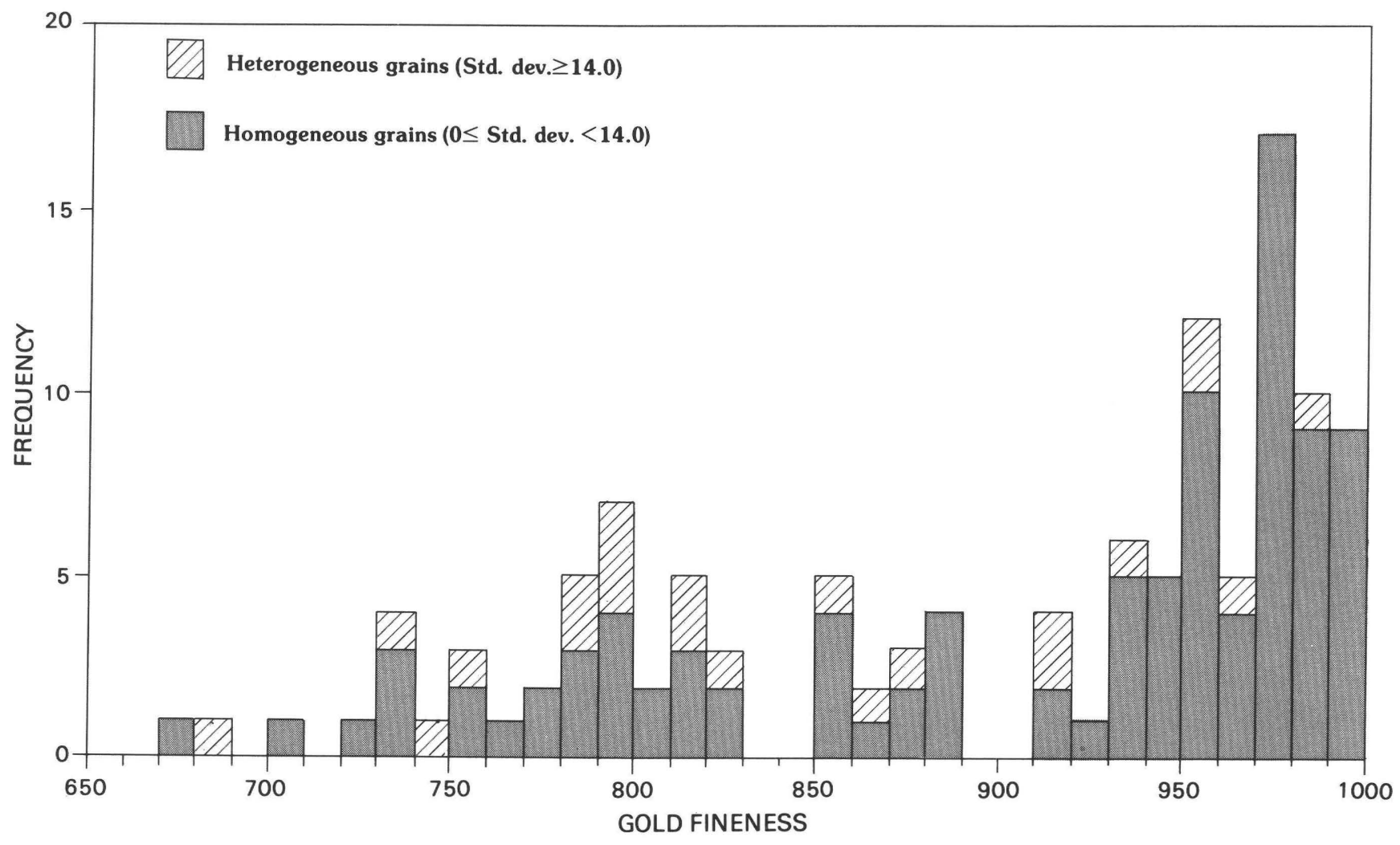

Figure 20. Histogram of gold fineness data, study area ( $n=121$ grains; 99 homogeneous, 22 heterogeneous). One measurement per gold grain (average fineness of microprobe points on gold grains). Microprobe analyses of each of 121 gold grains were averaged, resulting in 1 fineness value per grain. Grains were classified as homogeneous or heterogeneous according to standard deviation of microprobe values from each grain.

Miners Gulch. Chemical analyses show that soil, altered rock, and veins in this area contain higher amounts of molybdenum than samples from surrounding areas. Results of the geochemical studies show geochemical anomalies of molybdenum, antimony, arsenic, gold, tungsten, and barium within or around the pervasively altered zone (figs. 11-15). The anomaly is coincident with magnetic and gravity anomalies.

\section{Geophysical Studies}

A complete Bouguer gravity anomaly map and a reduced aeromagnetic anomaly map were compiled for the study area from regional surveys conducted as part of the Butte $1^{\circ} \times 2^{\circ}$ CUSMAP geophysical study (Hassemer and Hanna, 1982).

Figure 22 shows part of the regional Bouguer gravity anomaly map. The Upper Willow Creek valley lies within a north-trending gravity low. A minor gravity low, indicated by the -200 isogal, is centered just northeast of the center of the Miners Gulch stock. This anomaly indicates the existence of a small mass of lower density rock coincident with the molybdenum anomaly. The gravity low reflects either the strong pervasive alteration in the area or a lower density intrusion at depth, or both.

On the aeromagnetic map (fig. 23), the Miners Gulch stock is characterized by a strong positive magnetic anomaly. This anomaly indicates that the stock is approximately circular in plan view and is steep sided to the north, south, and west. The magnetic signature is that of a strong dipole with the negative pole north of the stock indicating that the stock is most likely a cylindrical body oriented with a strong component of northerly dip (W. F. Hanna, oral commun., 1983).

An area of lower magnetic intensity disrupts the generally circular pattern of the isogams in sec. $30, \mathrm{~T}$. $8 \mathrm{~N}$., R. $15 \mathrm{~W}$. This area coincides with the $-200 \mathrm{mGal}$ gravity low (fig. 22). It is also coincident with the pervasively altered zone, the outcrop of the porphyritic granodiorite plug, and the molybdenum anomaly. The negative magnetic anomaly is large and strong, and suggests that a greater volume of porphyritic granodiorite is present at depth than indicated by the outcrop pattern. The anomaly makes it difficult to interpret the eastern margin of the Miners Gulch stock. The contact may be 

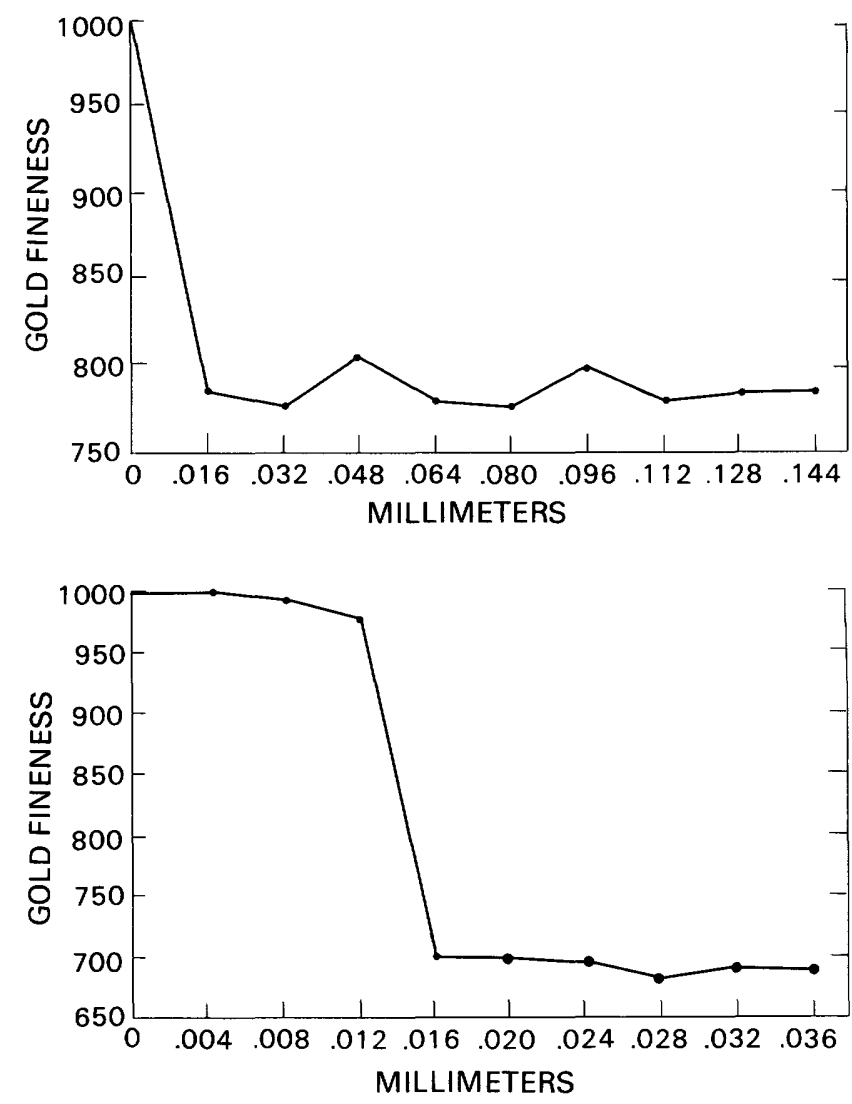

Figure 21. Graphs showing variations in gold $(\mathrm{Au})$ fineness from rims (left) to cores (right) of grains. Upper sample is from panned concentrate of alluvium in Alder Gulch (sample B2111, grain 2). Lower sample is from panned concentrate of stream terrace south of Sawpit Gulch (sample B2091, grain 5).

gently dipping, as the magnetic pattern would suggest, or the contact relationship may be obscured by alteration or by the presence of the porphyritic granodiorite plug.

\section{Discussion of Molybdenum Anomaly}

Geophysical and geochemical patterns demonstrate, in part, the existence of a previously unrecognized molybdenum anomaly in the Miners Gulch stock. Porphyry molybdenum systems may be associated with multiple porphyritic intrusions, and geologic and geophysical data in the Miners Gulch area suggest the presence of such intrusions. The presence of porphyritic rhyolite dikes and aplite dikes in outcrop, mostly in the NW $1 / 4 \mathrm{sec} .32, \mathrm{~T}$. $8 \mathrm{~N}$., R. $15 \mathrm{~W}$., supports the idea that multiple intrusions may be responsible for the aeromagnetic low. All the rhyolite dikes are moderately to strongly sericitically altered and are steeply dipping.

Hints of geochemical zoning also exist in the area. Antimony, arsenic, and possibly mercury indicate that a low-temperature mineral assemblage is present. The antimony-arsenic association is also spatially related to the quartz-sulfide stage of veining, as noted previously. The distribution of antimony and arsenic (fig. 11) and the highest gold values (fig. 12) each define semicircular halos at a radius of as much as $1.5 \mathrm{mi}$ from the center of the pervasively altered zone. High barium values are strongly concentrated within the molybdenum anomaly (fig. 13). High concentrations of barium are common both in ore bodies and in the associated halos of granodiorite molybdenum systems (Mutschler and others, 1981 , p. 875). Perhaps the barium mineralization represents the upper levels of a more deeply seated hydrothermal system. Conceivably, the barium was brought to the surface through the abundant near-vertical fractures caused by intrusion, overprinting this element on the older molybdenum mineralization. Few samples contained detectable tungsten, but those that did define a similar semicircular halo at a radius of about 1-2 mi from the pervasively altered zone (fig. 15). This halo is roughly the expected location for high antimony, mercury, gold, and tungsten concentration in a zoned porphyry molybdenum system.

The low-temperature mineral assemblage (antimony, arsenic, and mercury) mostly surrounds the barite mineralization but in some places overlaps it. The antimony and barite associations, recognized here as late stages of mineralization spatially related to the molybdenum anomaly and to each other, might be explained by the exhaustion of a hydrothermal cell in a developing porphyry molybdenum system. These element associations may be related to an additional hydrothermal cell, deeper and later than the first, and possibly related to the Tertiary rhyolite porphyry dike magmatism. Figure 24 shows an east-west geologic cross section across the Miners Gulch stock, including a possible rhyolite porphyry plug.

This geologic interpretation, to be considered plausible, must explain the strong showing of the antimony-arsenic association east of the anomalous molybdenum area and the poor showing to the west. As earlier discussed, the Upper Willow Creek valley was apparently tilted to the east during Pliocene and Pleistocene time. Thus, the rocks on the eastern edge of the Miners Gulch stock were downdropped relative to the rocks on the west. Consequently, veins exposed on the east side are less deeply eroded and preserve lower temperature assemblages than those veins exposed on the west side.

\section{Comparison of Molybdenum Anomaly to Known Porphyry Molybdenum Deposits}

Many similarities exist between the molybdenum anomaly and stock-type calcalkaline stockwork molybdenum deposits of a 80-60 m.y. old igneous belt that 
Table 15. Fineness ranges for sample types analyzed by electron microprobe

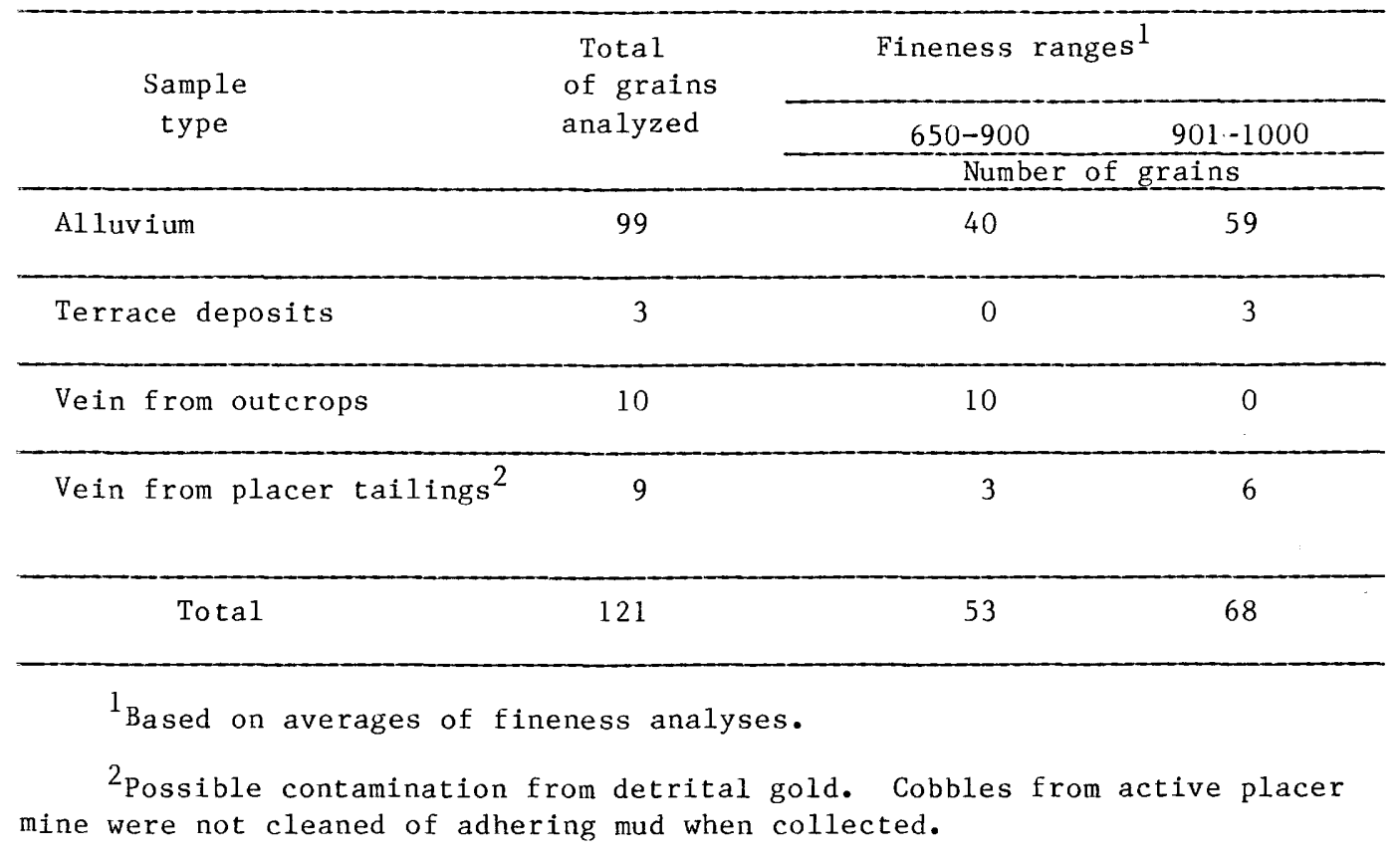

extends roughly south from British Columbia (Westra and Kieth, 1981). According to Westra and Kieth (1981, p. 850), "Stock-type molybdenum deposits are associated with crudely circular composite porphyritic stocks which are commonly less than 1,500 m in diameter." Stock-type deposits containing low fluorine concentrations in the zone of anomalous molybdenum, such as the Buckingham deposit in Nevada (Blake and others, 1979), show even greater similarities to the anomalous molybdenum area.

In the study area, 14 soil and 8 rock samples were analyzed for fluorine. Six of the soil samples and two of the rock samples were collected within the anomalous molybdenum area. Fluorine concentrations in soil samples ranged between 300 and $400 \mathrm{ppm}$ within the molybdenum anomaly and between 300 and $600 \mathrm{ppm}$ elsewhere in the Miner Gulch area. The two rock samples within the molybdenum area contained $200 \mathrm{ppm}$ and $700 \mathrm{ppm}$ fluorine. The two rock samples also contained $20 \mathrm{ppm}$ and $7 \mathrm{ppm}$ molybdenum, respectively. Outside the anomalous molybdenum area, fluorine values for rocks ranged from $100 \mathrm{ppm}$ to $2,600 \mathrm{ppm}$ and averaged $600 \mathrm{ppm}$. The one sample that contained 2,600 ppm fluorine contained no molybdenum. At the Buckingham, Nevada, porphyry molybdenum deposit (a fluorinedeficient molybdenum system) and at all comparable deposits, most analyses of molybdenum-rich rocks show fluorine concentrations in the range of $300-800 \mathrm{ppm}$ (Theodore, 1982).

The mineralogy of the Buckingham deposit also compares favorably with the mineralogy observed in the
Miners Gulch area. Theodore (1982) reported lead, arsenic, zinc, gold, and silver peripheral to the system, and locally, some traces of bismuthinite and stibnite outside the stockwork veins.

The mineralization in most fluorine-deficient molybdenum deposits, including Buckingham, is associated with calcalkaline intrusives of Late Cretaceous age that have been sericitically altered and contain conspicuous quartz phenocrysts. Most of the anomalous molybdenum samples from the study area also occur within a porphyritic granodiorite plug of Late Cretaceous or early Tertiary age that shows all these features.

Abundant, closely spaced quartz veinlets are considered diagnostic for fluorine-deficient molybdenum deposits. At Buckingham, molybdenum typically ranges from 70 to $300 \mathrm{ppm}$ within the stockwork (in contrast to $4 \mathrm{ppm}$ in surrounding rocks). Tungsten is somewhat anomalous (20-40 ppm) within the veined intrusive rock (Theodore, 1982). In the Miners Gulch area, parts of sec. 30 , T. 8 N., R. $15 \mathrm{~W}$., show strong crosscut veining, and molybdenum values are as high as $100 \mathrm{ppm}$ (the highest concentration of molybdenum in the study area). No molybdenite, however, was seen in hand specimens.

At Buckingham, emplacement of middle Tertiary rhyolite, quartz latite, and granite is considered partly responsible for high concentrations of silver, gold, lead, zinc, and arsenic and also for the remobilization of some molybdenum. The mineralizing episode is thought to have been controlled by existing structures (Theodore, 1982). Rhyolite and monzogranite also crop out as dikes in the Miners Gulch area and are intruded where the highest 


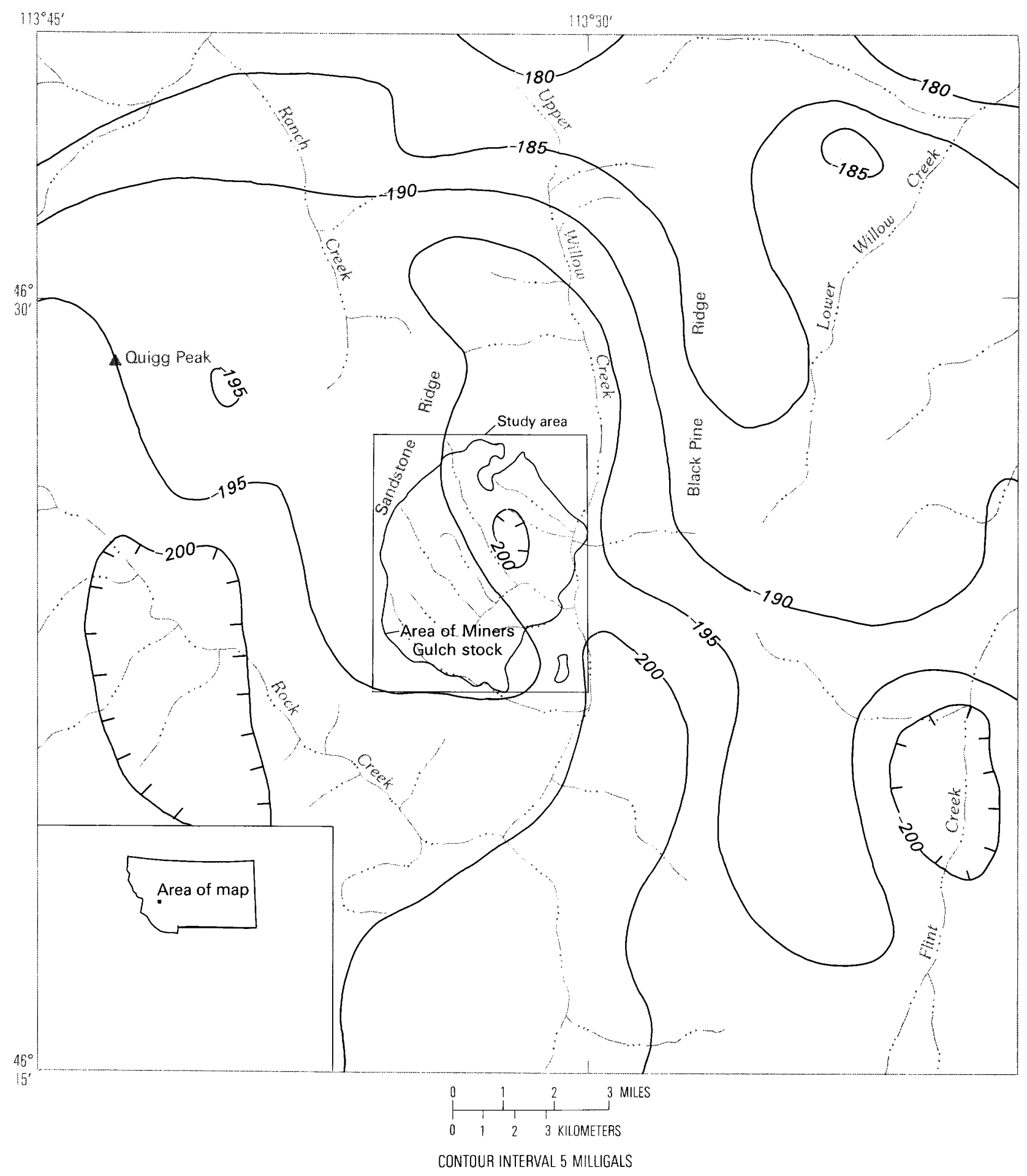

Figure 22. Gravity map, John Long and Sapphire Mountains, southwest Montana. Data from Hassemer and Hanna (1982), and W. F. Hanna (unpublished data).

concentrations of gold, silver, lead, copper, antimony, mercury, arsenic, and bismuth are found-along the eastern margin of the Miners Gulch stock. The ages of the rhyolite and monzogranite intrusives in the Miners Gulch area are not accurately known, but are probably early to mid-Tertiary. Minerals of the antimony and arsenic association are known from field evidence to have been deposited late in the veining sequence, because highly volatile elements (including mercury) and low temperature minerals (such as stibnite) would have been 


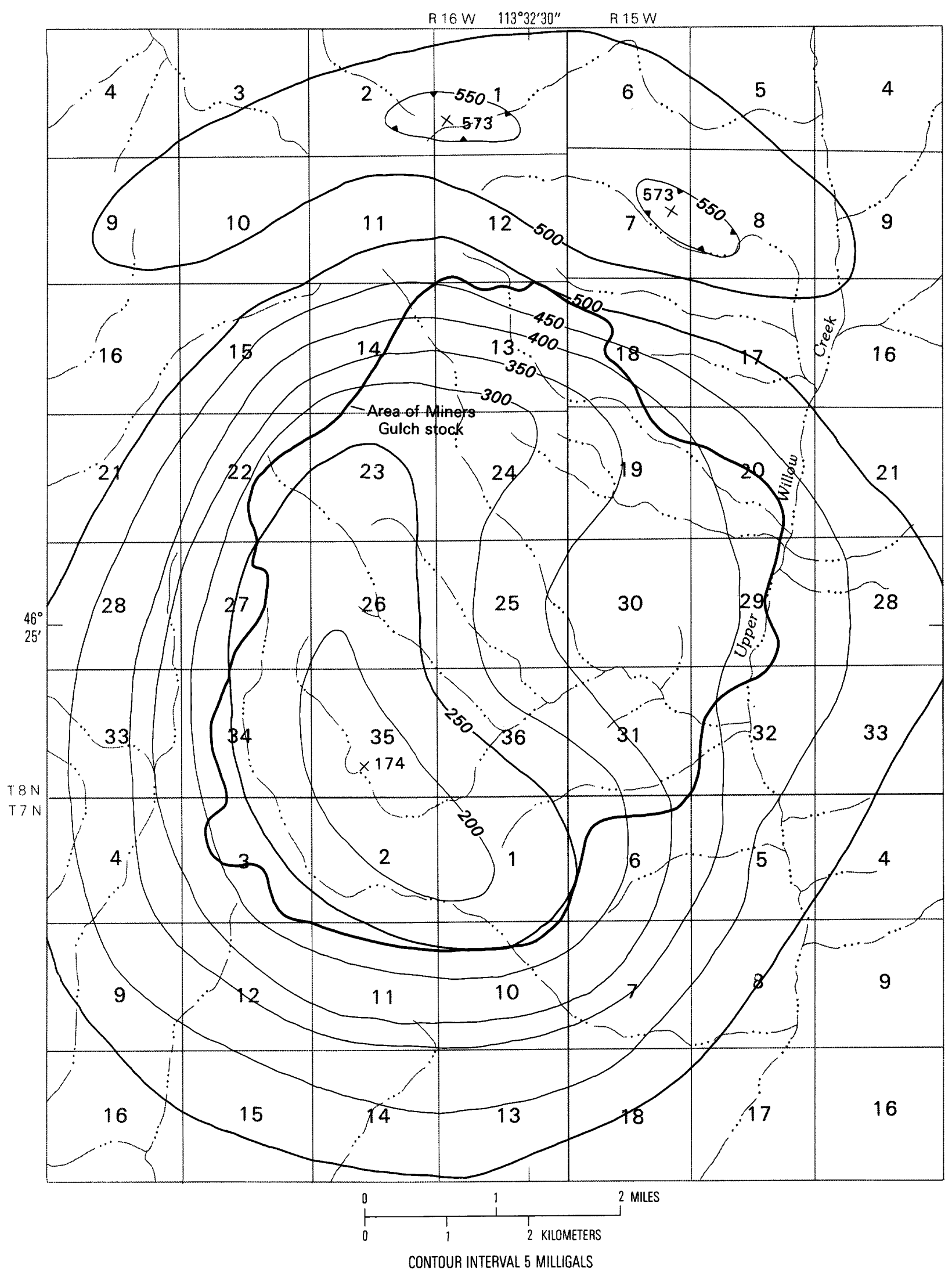

Figure 23. Aeromagnetic map of study area. Heavy line is outline of Miners Gulch stock. Sawteeth indicate magnetic lows. Data from Hassemer and Hanna (1982) and W. F. Hanna (unpublished data). 


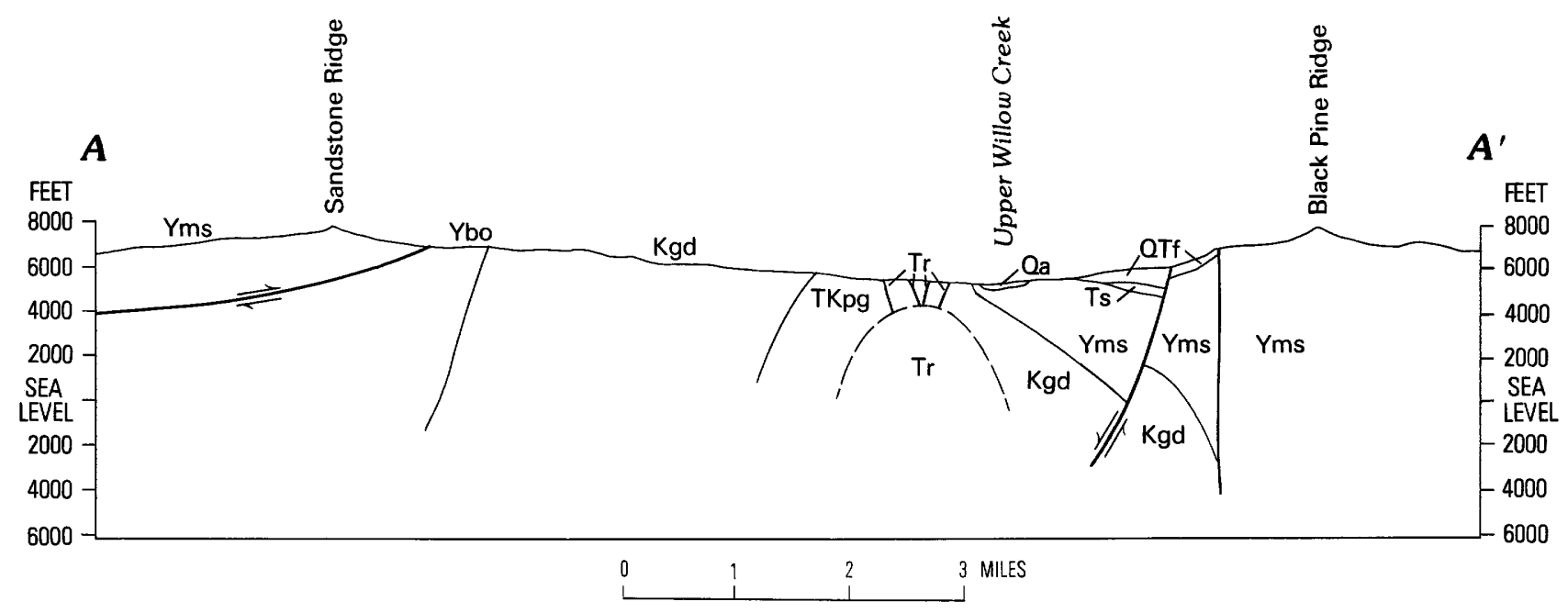

EXPLANATION

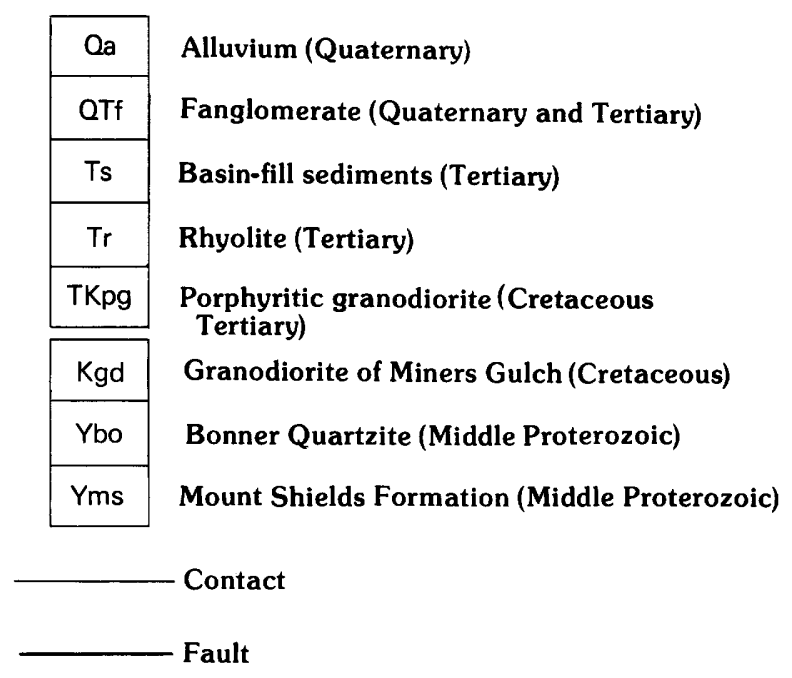

Figure 24. East-west geologic cross section through study area in vicinity of Miners Gulch. Interpretation of subsurface geology is based on aeromagnetic and gravity data, and on surface mapping.

lost from the association had they been deposited before molybdenum (fluid inclusions at Buckingham have a homogenization temperature of $250-350{ }^{\circ} \mathrm{C}$ ). The mineralization represented by the antimony-arsenic association may be the result of rhyolite intrusion and concentration along an unmapped structure on the eastern edge of the Miners Gulch stock or along the northwest-southeast joint trends in the stock.

Calc-alkaline stockwork molybdenum deposits in plutons similar to the Miners Gulch stock rarely exceed 0.25 percent molybdenite in hand samples, because of low initial molybdenum concentration in the parent magma and an effective concentration mechanism in the magma (Westra and Kieth, 1981). According to Westra and Kieth, high fluorine concentrations enhance molybdenum concentration processes, so fluorine-deficient calcalkaline magmas have much less favorable chemistry for molybdenum concentration processes than do fluorine-rich, alkali-calcic systems. Thus, although the molybdenum anomaly in the Miners Gulch area resembles known orebearing molybdenum deposits in the Western United States, the economic importance of this anomaly can only be evaluated through additional studies, preferably subsurface oriented.

\section{Origin of Gold Placer Deposits}

Frequency distributions of fineness analyses (fig. 20) defined two populations that are 659-900 and 901-1000 fine. These populations have been tentatively correlated with two gold different sources of gold for the placers of the Miners Gulch area. 
Samples from alluvium contained gold from both fineness populations, whereas samples from local veins contained gold of only the low population (less than 872 fine). The low-fineness populations in the alluvium thus may be derived predominantly from local veins. Fisher (1945) found a strong relationship between the temperature of hydrothermal gold deposits and the fineness of gold they contain. The gold population having the lowest fineness may be related to the late, low-temperature vein mineralization represented by the antimony-arsenic association. Sample analyses show a positive linear correlation between gold and antimony values $(r=0.46$, table 14). Epithermal veins, whose trace-metal chemistry is similar to that of the antimony-arsenic association, typically contain gold ranging from 500 to 800 fine (Fisher, 1945). (Fisher notes exceptions, apparently caused by solution of silver from the gold-silver alloy during oxidation of veins, at Cripple Creek, Colo., and Goldfield, Nev.).

The high-fineness population, from 901 to 1000 fine, was not represented in gold samples from veins. This population may have originated in either of two ways; gold from a remote source was transported to the area in high-level terrace gravels, or gold alloys from local veins may have been enriched in gold by solution of silver during oxidation of the veins or during stream transport. A remote source rather than solution of silver is indicated because all gold grains collected from oxidized veins in the study area showed fineness less than 900 , and the high-fineness grains contained no observable enriched edges. As shown in table 15, 59 percent of the analyzed gold grains from alluvium was of the high-fineness population. If this percentage represents the amount of gold contributed by a remote source, such as high-level gravels, the remote source was very important to the formation of placer gold concentrations. This percentage estimate may be biased in favor of the high-fineness population, however, because the gold samples were taken from above-bottom alluvium (the "allochthonous" placers of Kartashov, 1971). Above-bottom placers typically contain more gold from recycling of high-level terrace deposits than "autochthonous" or near-bedrock placers. According to Kartashov, autochthonous placers chiefly contain locally derived gold.

Nonetheless, the upper and lower terraces in the Miners Gulch area were apparently deposited in an ancestral river system related to the Tertiary drainage system. Geologic features in the study area indicate a close association between alluvial gold placers and the two terrace deposits. The areal distribution of the placer workings (pl. 1) coincides with the area of greatest erosion and reworking of the terrace alluvium. The placer deposits consist of alluvium composed chiefly of rounded quartzite cobbles derived from the terrace deposits, suggesting a gold source in the terrace deposits.
Analyses of gold from the lower terrace deposits are of the high fineness population (no gold was recovered from samples of the upper terrace deposits). Average values of high-fineness population gold grains for alluvium sites, plotted on a map (fig. 25), are consistently 950-960 fine throughout the study area. This even distribution of the high-fineness gold is best explained by its deposition in a blanket-like medium, such as a highlevel fluvial terrace. Average values for the lower fineness population in samples taken from alluvium show considerable areal variation, reflecting probable derivation from local vein sources.

Lindgren (1911) studied placers formed partly from the reconcentration of gold-bearing Tertiary alluvium deposited by ancestral rivers in the Sierra Nevada, Calif. He cited solution of silver in the stream environment as a valid cause of the higher fineness of placer gold and made the following observations about regional fineness analyses:

"The [fineness] figures quoted show very clearly that in the main Tertiary streams a considerable refining of the gold has been going on, so that the average grade is now decidedly above 900 . It is difficult to compare accurately the tenor of the gold in the present streams with that in the Tertiary channels, for it must be remembered that the former contain a mixture of detrital gold derived from Tertiary channels with much new gold set free during the erosion of the present canyon system."

A situation analogous to the above description seems to be present in the study area. The reversal of Upper Willow Creek in early Pleistocene time caused streams to incise into the upper and lower terrace deposits in order to re-establish a reasonable grade to the new, drastically lowered base level. This incision probably involved periodic sediment storage and transport in various parts of the fluvial system. The complex response of the drainage basin to rejuvenation may thus have caused the multiple reworking of stream deposits necessary for fluvial placer formation (Adams and others, 1978).

As stream incision progressed, weathering of the Miners Gulch stock released gold from local veins. This local gold, predominantly of low fineness, accumulated in colluvium and was gradually transferred to alluvium by hillslope processes such as slope wash, creep, and landsliding. Gold from the upper and lower terrace gravels was also delivered to alluvium after being temporarily stored in colluvial deposits. Mackin and Schmidt (1956) suggested that downslope movement of enriched mantle was accelerated during periods of periglacial climate accompanying glacial advances. Because the major placers are of late Pleistocene age and the study area is about $1,800 \mathrm{ft}$ below the local limit of Pleistocene glaciation, periglacial processes probably influenced placer development in the study area. During glacial stages, streams in the study area were heavily charged with runoff and had 


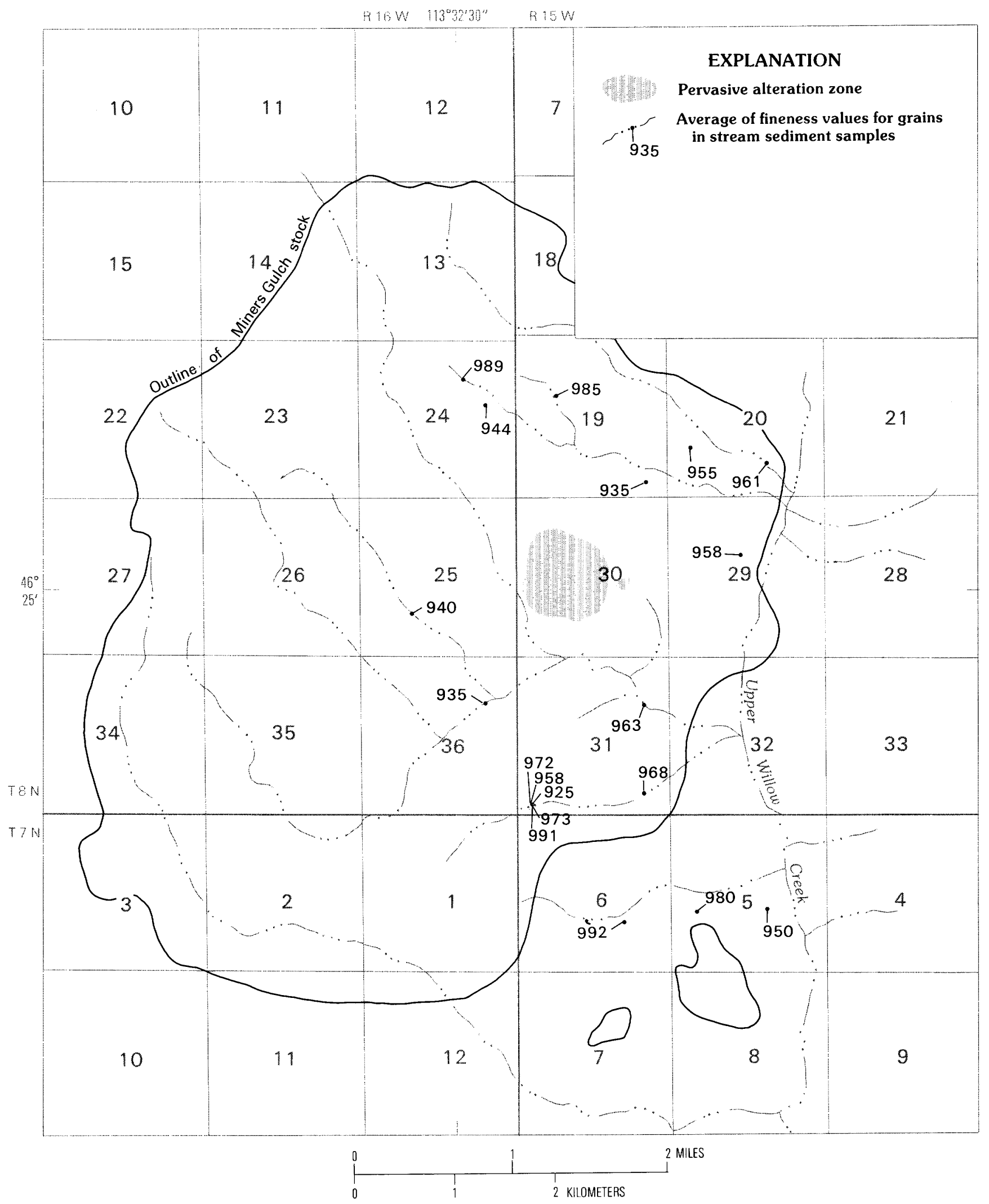

Figure 25. Distribution of average fineness of gold grains with fineness $>900$ in stream-sediment samples. 
sufficient power to concentrate heavy minerals and resistant rocks delivered by invigorated hillslope processes while removing lighter rocks. Placers developed in stream channels and in small alluvial fans at the mouths of streams. The natural morphologic and sedimentologic development of fluvial fans (repeated fan-head trenching) concentrated gold delivered from the basins (Schumm, 1978), and development of secondary fans resulted in further reworking of the gold-bearing deposits. The finegrained sediments that characterize the Holocene suggest that, since the Pleistocene, the area has lacked sufficient water to cause deep channel scouring during floods.

\section{REFERENCES CITED}

Adams, John, Zimpfer, G. L., and McLane, C. F., 1978, Basin dynamics, channel processes, and placer formation-A model study: Economic Geology, v. 73, p. 416-426.

Alden, W. C., 1953, Physiography and glacial geology of western Montana: U.S. Geological Survey Professional Paper 231, $200 \mathrm{p}$.

Alt, David, and Fields, R. W., 1971, Tertiary paleoclimate and origin of drainage-Northern Rocky Mountains: Geological Society of America Abstracts with Programs, v. 3, no. 2, p. 71.

Anderson, A. L., 1947, Drainage diversion in the northern Rocky Mountains of east-central Idaho: Journal of Geology, v. 55, p. 61-75.

Atwood, W. W., 1916, The physiographic conditions at Butte, Montana, and Bingham Canyon, Utah, when the copper ores in these districts were enriched: Economic Geology, v. 11, p. $697-740$.

Bateman, A. M., 1950, Economic mineral deposits (2nd ed.): New York, John Wiley and Sons, 916 p.

Berg, R. B., 1982, Barite occurrences in Montana: Montana Bureau of Mines and Geology Open-File Report MBMG-95, $10 \mathrm{p}$.

Blake, D. W., Theodore, T. G., Batchelder, J. N., and Kretschmer, E. L., 1979, Structural relations of igneous rocks and mineralization in the Battle Mountain mining district, Lander County, Nevada, in Ridge, J. D., ed., Papers on mineral deposits of western North America: Nevada Bureau of Mines Geology Report 33, p. 87-99.

Blaskowski, M. J., Loen, J. S., and Elliott, J. E., 1983, Map showing geology and mineral deposits of the southeast part of the Alder Gulch quadrangle, Granite County, Montana: U.S. Geological Survey Open-File Report 83-414, scale $1: 10,000$.

Bull, W. B., 1977, The alluvial-fan environment: Progress in Physical Geography, v. 1, no. 2, p. 222-270.

Capps, S. R., 1941, Faulting in western Idaho and its relation to the high placer deposits: Idaho Bureau of Mines and Geology Pamphlet 52, $20 \mathrm{p}$.

Desborough, G. A., 1970, Silver depletion indicated by microanalysis of gold from placer occurrences, Western United States: Economic Geology, v. 65, p. 304-311.

Dietrich, W. E., and Dorn, Ronald, 1984, Significance of thick colluvium on hillslopes-a case study involving the use of pollen analysis in the coastal mountains of California: Journal of Geology, v. 92, p. 147-158.

Eaton, G. P., Wahl, R. R., Prostka, H. J., Mabey, D. R., and Kleinkopf, M. D., 1978, Regional gravity and tectonic patterns - their relations to late Cenozoic epeirogeny and lateral spreading of the western Cordillera: Geological Society of America Memoir 152, p. 51-92.

Fisher, N. H., 1945, The fineness of gold, with special reference to the Morobe goldfield, New Guinea: Economic Geology, v. 40 , no. 7 , p. $449-495$.

Geist, Valerius, 1971, The relation to social evolution and dispersal in ungulates during the Pleistocene, with emphasis on the Old World deer and the genus Bison: Quaternary Research, v. 1, p. 283-315.

Griffith, S. V., 1960, Alluvial prospecting and mining (2d ed.): New York, Pergamon Press, 245 p.

Guthrie, R. D., 1970, Bison evolution and zoogeography in North America during the Pleistocene: The Quarterly Review of Biology, v. 45, p. 1-15.

Hassemer, J. H., and Hanna, W. F., 1982, Slides showing preliminary mosaic, magnetic, and complete Bouguer gravity anomaly maps of the Butte $1^{\circ} \times 2^{\circ}$ quadrangle, Montana: U.S. Geological Survey Open-File Report 82-0603.

Hughes, G. T., 1970, Precambrian stratigraphy and structure in the Henderson-Willow Creek igneous belt, Granite County, Montana: Houghton, Michigan Technological University, M.S. thesis, $93 \mathrm{p}$.

1971, Petrology and tectonic setting of igneous rocks in the Henderson-Willow Creek igneous belt, Granite County, Montana: Houghton, Michigan Technological University, Ph.D. thesis, 236 p.

1975, Relationship of igneous rocks to structure in the Henderson-Willow Creek igneous belt, Montana: Northwest Geology, v. 4, p. 15-25.

Kartashov, I. P., 1971, Geological features of alluvial placers: Economic Geology, v. 66, p. 879-885.

Koschmann, A. H., and Bergendahl, M. H., 1968, Principal gold-producing districts of the United States: U.S. Geological Survey Professional Paper 610, 283 p.

Lindgren, Waldemar, 1911, The Tertiary gravels of the Sierra Nevada of California: U.S. Geological Survey Professional Paper 73, 226 p.

Lyden, C. J., 1948, The gold placers of Montana: Montana Bureau of Mines and Geology Memoir 26, $152 \mathrm{p}$.

Macke, D. L., 1977, Stratigraphy and sedimentology of experimental alluvial fans: Fort Collins, Colorado State University M.S. thesis.

Mackin, J. H., and Schmidt, D. L., 1956, Uranium and thorium-bearing minerals in placer deposits in Idaho: International Conference on the Peaceful Uses of Atomic Energy, v. 6 (Geology of uranium and thorium), p. 587-592.

Mutschler, F. E., Wright, E. G., Ludington, Steven, and Abbott, J. T., 1981, Granite molybdenite systems: Economic Geology, v. 76, no. 4, p. 874-897.

Pardee, J. T., 1950, Late Cenozoic block faulting in western Montana: Geological Society of America Bulletin, v. 61, p. $359-406$.

1951, Gold placer deposits of the Pioneer district, Montana: U.S. Geological Survey Bulletin 978-C, p. 69-99. 
Pierson, T. C., 1980, Piezometric response to rainstorms in forested hillslope drainage depressions: Journal of Hydrology, v. 19, p. 1-10.

Rapp, Anders, 1960, Recent development of mountain slopes in Karkevagge and surroundings, northern Scandinavia: Geografiska Annaler, v. 42, p. 65-200.

Rasmussen, D. L., 1973, Extension of the middle Tertiary unconformity into western Montana: Northwest Geology, v. 2, p. 27-35.

Reynolds, M. W., 1979, Character and extent of basin-range faulting, western Montana and east-central Idaho: Rocky Mountain Association of Geologists, Basin and Range Symposium, p. 185-193.

Robinson, G. D., 1963, Geology of the Three Forks Quadrangle, Montana: U.S. Geological Survey Professional Paper 370, 143 p.

Rowe, J. P., 1911, Placer mining operations in western Montana: Mining World, v. 34, p. 877.

Ruppel, E. T., 1967, Late Cenozoic drainage reversal, eastcentral Idaho, and its relation to possible undiscovered placer deposits: Economic Geology, v. 62, p. 648-663.

Ruppel, E. T., Wallace, C. A., Schmidt, R. G., and Lopez, D. A., 1981, Preliminary interpretation of the thrust belt in southwest and west-central Montana and east-central Idaho: Montana Geological Society Field Conference Guidebook, p. 139-159.

Saunders, Ian, and Young, Anthony, 1983, Rates of surface processes on slopes, slope retreat and denudation: Earth Surface Processes and Landforms, v. 8, p. 473-501.

Schumm, S. A., 1978, Experimental studies of fluvial placers [abs.], in Miall, A. D., ed., Fluvial sedimentology: Canadian Society of Petroleum Geologists Memoir 5, p. 856.

Schumm, S. A., and Parker, R. S., 1973, Implications of complex response of drainage systems for Quaternary alluvial stratigraphy: Nature, Physical Science, v. 243, p. 99-100.

Shakhtyrov, V. G., and Shumilov, Yu, V., 1981, Suffosional residual placers, a new genetic type of gold placer: Doklady, Earth Science Sections, v. 246, p. 69-71.

Taysayev, T. T., 1983, Suffosion on rock-stream slopes and associated secondary dispersion halos: Doklady, Earth Science Sections, v. 257, p. 67-71.

Theodore, T. G., 1982, Preliminary model outline for fluorinedeficient porphyry molybdenum deposits, in Erickson, R. L., compiler, Characteristics of mineral deposit occurrences: U.S. Geological Survey Open-File Report 82-795, p. 33-38.

U.S. Geological Survey, 1980, Geological Survey Research, 1980: U.S. Geological Survey Professional Paper 1175, 459 p.

Wallace, C. A., Schmidt, R. G., Waters, M. R., Lidke, D. J., and French, A. B., 1981, Preliminary geologic map of parts of the Butte $1^{\circ} \times 2^{\circ}$ quadrangle, central Montana: U.S. Geological Survey Open-File Report 81-1030, scale 1:250,000.

Westra, Gerhard, and Kieth, S. B., 1981, Classification and genesis of stockwork molybdenum deposits: Economic Geology, v. 76, p. 844-873.

Wilson, M., 1980, Morphological dating of late Quaternary bison on the northern plains: Canadian Journal of Anthropology, v. 1, no. 1, p. 81-85.

Young, Anthony, 1972, Slopes: Edinburgh, Oliver and Boyd, 288 p. 

Chapter B

Colluvial Gold Placers

Near Miners Gulch,

Granite County, Montana

BY JEFFREY S. LOEN

U.S. GEOLOGICAL SURVEY BULLETIN 1791

GEOLOGY AND MINERAL DEPOSITS OF THE MINERS GULCH AREA, GRANITE COUNTY, MONTANA 


\section{CONTENTS}

Abstract B1

Introduction B1

Geology B1

Description of colluvial deposits B2

Mode of formation $\mathbf{B 3}$

Conclusion B3

Acknowledgments B5

References cited B5

FIGURES

1. Map showing the location of the study area, the regional drainage system, placer-mined areas, and important geologic and geographic features $\mathbf{B 2}$

2. Generalized geologic map of part of the Miners Gulch area B4

3. Representative stratigraphic column of gold-bearing colluvium, Miners Gulch area B5 


\title{
Colluvial Gold Placers
} Near Miners Gulch,

\section{Granite County, Montana}

\author{
By Jeffrey S. Loen
}

\begin{abstract}
Colluvial placers were mined during the late 19th century near Miners Gulch, Granite County, Mont. The colluvial deposits occupy U-shaped bedrock depressions in drainage headwaters. The bedrock depressions developed by the deepening and widening of joints in granodiorite of the Miners Gulch stock by weathering, followed by landsliding of the weathered debris and refilling with upslope sediment. The stratigraphy of the colluvial deposits consists chiefly of alternating layers of gravel and sand. Slope processes associated with infrequent torrential rainstorms, alternating with normal slope processes, produced the alternating coarse (gold-bearing) and fine (barren) layers. Gold was concentrated from low-grade terrace deposits and local veins.

Colluvial placers are genetically distinct from eluvial or residual placers (formed by in-situ weathering of primary lode gold). Some placers in the western United States, formerly identified as eluvial or residual, may have formed by concentration of low-grade gold by colluvial processes and by slope processes associated with torrential rainwash rather than by eluvial processes.
\end{abstract}

\section{INTRODUCTION}

Gold placers that are remote from stream channels have previously been categorized as "residual mantle" or "eluvial placers" (Lindgren, 1933; Pardee, 1933; Bateman, 1950; Boyle, 1979). These deposits result from deep, in-situ weathering of a primary gold lode. Colluvial placers, genetically distinct from eluvial placers (Macdonald, 1983), result from the concentration of gold in hillslope debris by sheetwash and rilling.

Geomorphic studies have determined that processes of hillslope development can involve the accumulation of colluvium in depressions in bedrock, followed by periodic erosion and slow refilling of the depressions. This process is important in controlling the discharge of hillslope sediments into stream channels. In gold-bearing areas, such colluvial processes also control the supply of detrital gold delivered to developing stream placers. Locally, the colluvium itself may constitute placer deposits of commercial grade.
Colluvial placers occur near Miners Gulch, in the John Long Mountains northwest of Philipsburg, Mont. (fig. 1). Alluvial placers in the Miners Gulch area were mined intensively beginning in the late 1860's (Loen and others, Chapter A, this volume). The colluvial deposits, which fill troughlike depressions in granodiorite, grade into these alluvial placers. About 40 acres of the surficial mantle on the hillsides, remote from active drainage channels, was mined.

The objective of this report is to describe general features of the colluvial placers near Miners Gulch and to evaluate their mode of origin and regional significance. The study area is in nonglaciated drainage at an elevation of about $5,500 \mathrm{ft}$ on the west side of the Upper Willow Creek Valley. Upper Willow Creek is a tributary to Rock Creek, which flows into the Clark Fork River south of Clinton, Mont.

Gold was discovered in Miners Gulch in 1867. During the following 20 years placer ground was mined along about 17 linear mi of stream channels in 8 main drainages within a $21 \mathrm{sq} \mathrm{mi}$ area (Blaskowski and others, 1983), including colluvial deposits in drainage headwaters. Several tens of miles of ditches were constructed in order to mine the alluvial and colluvial placers. Between 1880 and 1900 , numerous quartz veins were prospected. Two small lode mines near Miners Gulch may have then produced gold. Mining activity during the early 1980's included the exploration for commercial placer gold deposits throughout the area, and the operation of two small-scale, goldwashing plants in Sawpit Gulch (fig. 1).

\section{GEOLOGY}

The study area is underlain chiefly by the Miners Gulch stock, a 70.6-m.y.-old granodiorite pluton that intruded into Middle Proterozoic sedimentary rocks (Hughes, 1971, 1975). The stock is characterized by strong, near-vertical, nearly orthogonal jointing trending N. $60^{\circ}$ E. and N. $30^{\circ} \mathrm{W}$. The jointing influences the trends of hills and stream segments and the location of 


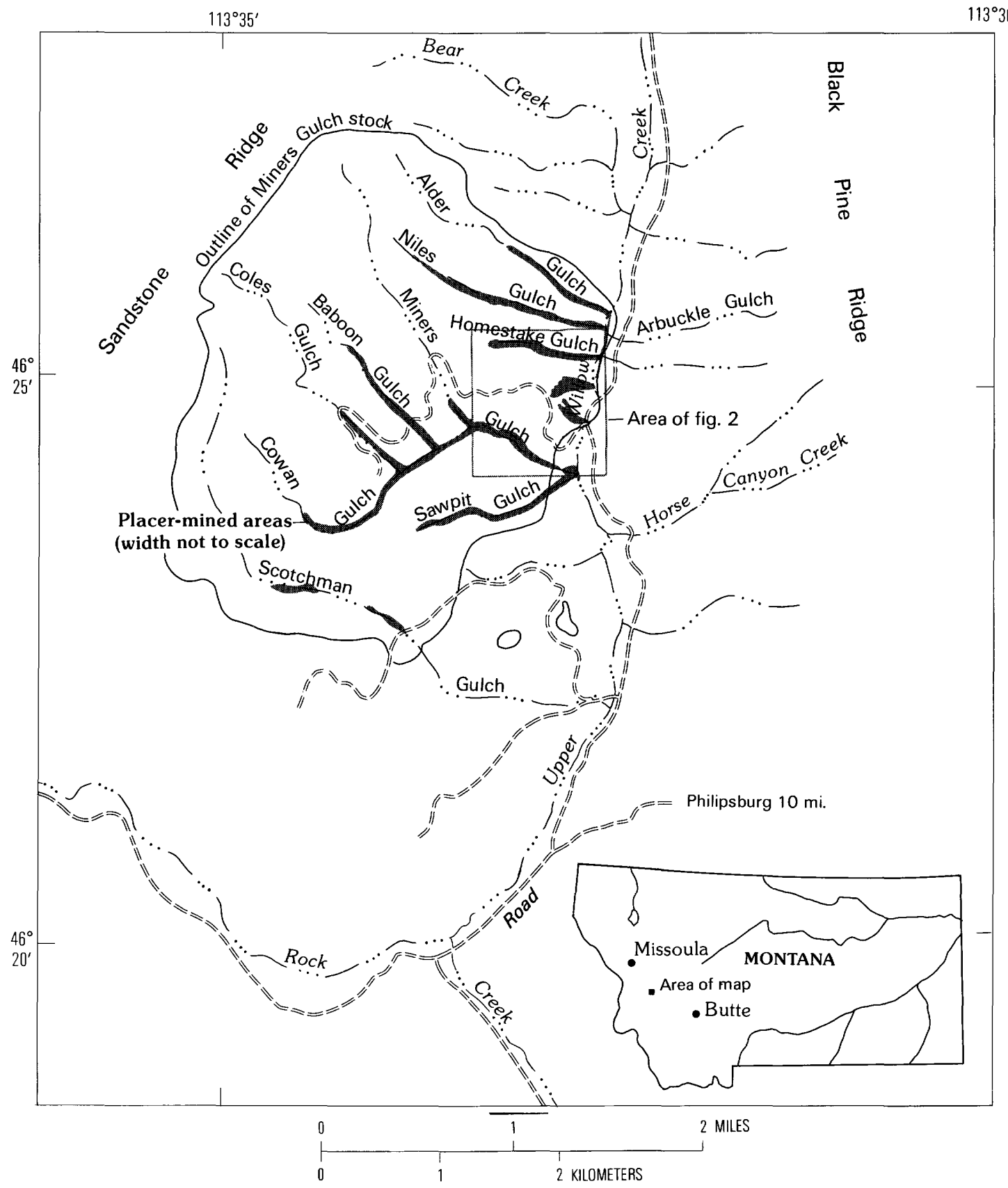

Figure 1. Map showing the location of the study area, the regional drainage system, placer-mined areas, and important geologic and geographic features.

dikes and gold-bearing quartz and barite veins. Outcrops of spheroidally weathered granodiorite typically form pinnacles and knobs as much as $140 \mathrm{ft}$ high.

Hills in the area of the stock are capped by remnants of terrace gravels of Pliocene(?) and early Pleistocene age which were deposited by an ancestral Upper Willow Creek. The terrace deposits occur $300-500 \mathrm{ft}$ topographically above Upper Willow Creek. The terrace remnants are composed of 3 to $30 \mathrm{ft}$ of gravel in a sandy clay matrix.

\section{Description of Colluvial Deposits}

The colluvial deposits form hillslope surfaces in the headwaters of first-order drainages bordering hills capped by terrace deposits. Where undisturbed, these hillslope surfaces are typically smooth. Because of soil and forest cover, the deposits are difficult to distinguish from granodiorite bedrock except where the deposits are exposed in pits and trenches.

The best exposures of gold-bearing colluvium are 
on a broad hillside between Homestake and Miners Gulches (fig. 2), where the placers were mined by an intricate system of placer-mining cuts. The deposits in this area occupy U-shaped bedrock depressions that parallel major joint sets. The deposits are 10-20 ft wide, 5-10 ft thick, and thin uphill.

The colluvium is composed of gravel-sized clasts of rounded, feldspathic quartzite derived from terrace deposits, and of spheroidal granodiorite and angular quartz vein clasts from the stock; these clasts are interlayered with grus and, locally, with white claypresumably weathered volcanic ash (fig. 3). Tailings piles contain about 70 percent feldspathic quartzite clasts, 20 percent granodiorite boulders, and 10 percent quartz vein clasts. Miners report that gravel-enriched layers locally contain large amounts of coarse gold, and that relatively small amounts of very fine grained gold are present in the grus layers.

The age of the colluvium is not precisely known. However, weathering features suggest a Pleistocene or Holocene age. Soils are weakly developed, and total 1-2.5 $\mathrm{ft}$ thick. Argillic B horizons locally range from .4 to .8 in. thick and contain an estimated 5-10 percent pedogenic clay. Granodiorite boulders within the colluvium are decomposed and are surrounded by iron-oxide weathering rinds. Gravel layers between beds of grus typically show notable iron-oxide stain because of oxidation of iron-bearing minerals by ground-water percolation.

\section{Mode of Formation}

Hillslopes in the study area formed when the present drainage system was incised in early to midPleistocene time (Loen and others, Chapter A, this volume). At that time, streams cut through the terrace deposits into granodiorite of the Miners Gulch stock. Locally, the terrace gravels formed caprocks on hills and ridges because of the high resistance of the quartzite clasts to chemical weathering. Surface waters tended to percolate through the gravels rather than forming stream courses on the gravel surfaces.

Depressions in bedrock formed because bedrock joints localized weathering effects. Water movement toward the center of developing depressions (Pierson, 1980) caused deepening of the joints by frost wedging, hydration of biotite, solution of nonresistant bedrock minerals, and possibly by removal of small mineral particles in suspension. During early stages of hillslope development, joints widened and deepened. As the jointcontrolled depressions became filled with grus and with sediment shed from surrounding hillslopes, mass movement became the dominant surficial process.

Recent studies in the Pacific Northwest have linked the formation of colluvial deposits in bedrock depressions on slopes to landsliding (Dietrich and Dunne, 1978; Dietrich and others, 1982; Marron, 1982; Lehre, 1982a, 1982b; Swanson and Fredriksen, 1982; Dietrich and Dorn, 1984). In earlier studies such deposits were interpreted as stream gullies that were filled by fluvial action (Bryan, 1940; Beaty, 1959; Mills, 1981). The geometry and distribution of the bedrock depressions in the Miners Gulch area suggest that they were formed by landsliding, rather than by fluvial action. The depressions display U-shaped cross sections and lack the V-shaped notches characteristic of fluvial channels. Many of the colluvial deposits are located on steep slopes near ridgetops, where landsliding is a more likely process than is effective stream flow. Clasts of locally derived rock types in the deposits show no rounding, indicating movement by slope processes rather than by streams.

The bedrock depressions left as a result of landsliding are filled with sediment transported from adjacent slopes. Grus is transported downhill by rainfall, creep, and biogenic activity, resulting in grus layers that contain few coarse-sized clasts. Runoff during rainstorms in small drainage areas is variable, and the coarsest sediments are carried only by overland flow during torrential storms of low recurrence interval (Wolman and Miller, 1960; Mills, 1981). During infrequent catastrophic rainstorms, pebbles, cobbles, and-sometimes-boulders are mobilized by overland flow and are deposited in the topographic depressions. As coarse-sized clasts accumulate in the depressions, the frictional resistance of the surface is increased and overland flow is retarded, causing deposition. Fine sediments are removed by runoff, leaving coarse and heavy particles as a lag deposit which armors the underlying sand. This lag deposit contains gravel-sized rocks and mineral grains (including gold) of similar hydraulic equivalence.

Pleistocene or Pliocene(?) terrace deposits and local quartz veins are low-grade sources of placer gold which accumulates in the colluvium. Neither of these sources appears to contain gold in commercial concentrations in the Miners Gulch area (Loen and others, Chapter A, this volume). However, the terraces and veins, together, furnished gold for fluvial and colluvial placers which were mined extensively.

\section{CONCLUSION}

Gold placers on hillslopes, which have been termed “colluvial placers," have previously been described by Parker (1974) and Macdonald (1983). Most productive fluvial placers depend upon extensive colluvial deposits for their sediment supply (Macdonald, 1983). However, advances in the understanding of hillslope processes have not been applied to the majority of known gold placers on hillslopes, which have traditionally been classified as "residual" or "eluvial" placers. 


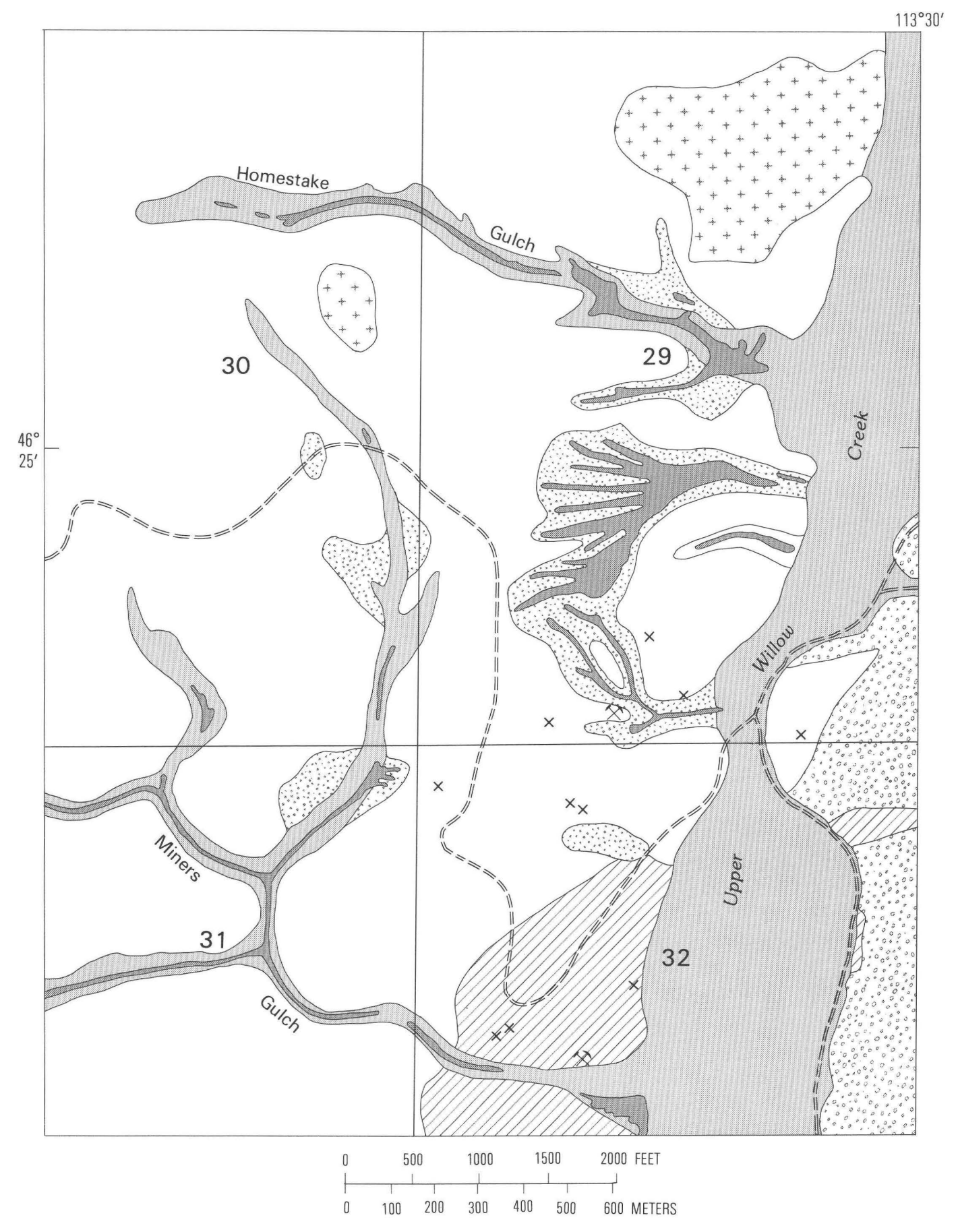

EXPLANATION

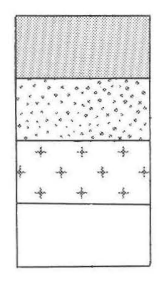

Alluvium (Holocene and Pleistocene)
Colluvium (Holocene and Pleistocene)
Terrace deposits (Pleistocene or Pliocene)
Fanglomerate (Quaternary and Tertiary)

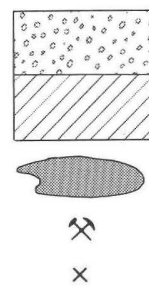

Granodiorite of Miners Gulch (Upper Cretaceous)

Mount Shields Formation (Middle

Proterozoic)

Placer-mined area

X Prospect

Figure 2. Generalized geologic map of part of the Miners Gulch area. Mapped by J. S. Loen and M. J. Blaskowki, 1982-83. Section numbers refer to T. 8 N., R. 15 W. Colluvium is more extensive than shown, but it is typically too thin to map. Location of figure is shown on figure 1. 


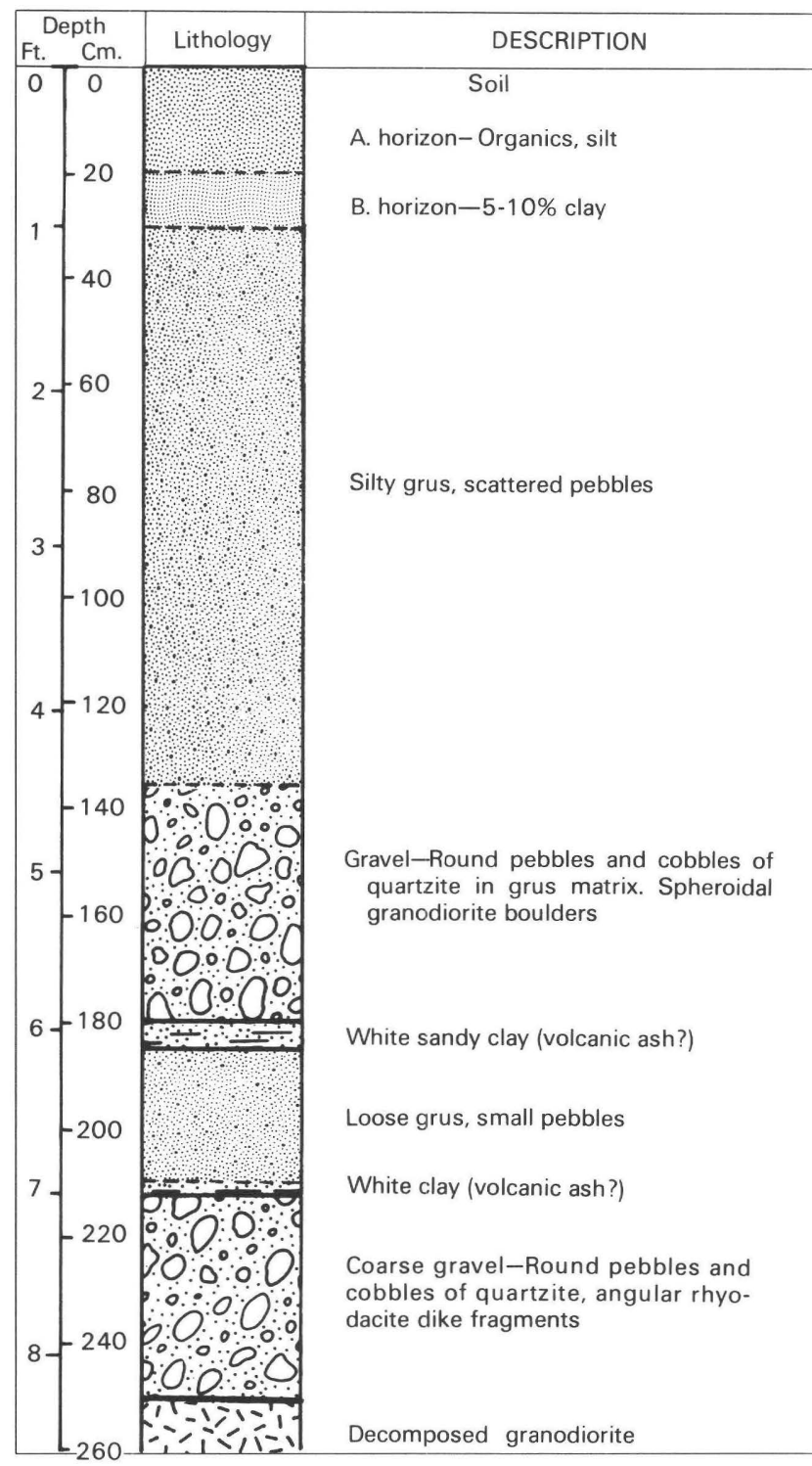

Figure 3. Representative stratigraphic column of gold-bearing colluvium, Miners Gulch area.

"Residual" and "eluvial" placers have been described in Arizona (Hill, 1910; Jones, 1916), California (Pardee, 1933; Jenkins, 1935), Colorado (Parker, 1974), Idaho (Hite, 1933; Lorain and Metzger, 1939; Anderson, 1953; Mackin and Schmidt, 1956; Hubbard, 1957; Choate, 1962), Oregon (Diller, 1914; Shenon, 1933), Montana (Pardee, 1933; Lyden, 1948), and Nevada (Ferguson, 1917, 1922). Boyle (1979) described eluvial placers in Canada and in other countries.

Many hillslope placers in the western U.S. are more similar to the colluvial placers at Miners Gulch than to "residual" or "eluvial" placers. Because eluvial placers result from the in-situ decomposition of rock (Bates and Jackson, 1980) they form only from rich primary gold lodes. At Miners Gulch, and at other hillslope placers in the Western United States, rich primary lodes are not present. These placers appear to form by slope processes that concentrate gold from low-grade gold sources. The higher grade gold placers that result should be termed "colluvial placers."

Colluvial placers form through genetic processes which are distinct from the processes that form eluvial placers. Little quantitative information is available about colluvial placers. Additional geomorphic study of colluvial deposits and increased awareness of colluvial processes by economic geologists are needed before the regional economic significance of colluvial placers will be known.

\section{ACKNOWLEDGMENTS}

M. R. Waters, J. E. Elliott, and G. A. Desborough of the U.S. Geological Survey, and M. D. Harvey, S. A. Schumm, and M. E. McCallum of Colorado State University contributed helpful discussions and useful comments on the manuscript. This study was conducted as part of the CUSMAP (Conterminous United States Mineral Assessment Program) study of the Butte $1^{\circ} \times 2^{\circ}$ quadrangle, Montana.

\section{REFERENCES CITED}

Anderson, A.L., 1953, Gold-copper-lead deposits of the Yellowjacket district, Lemhi County, Idaho: Idaho Bureau of Mines and Geology Pamphlet No. 94, 41 p.

Bateman, A.M., 1950, Economic mineral deposits (2d ed.): New York, John Wiley, 916 p.

Bates, R.L., and Jackson, J.A., eds., 1980, Glossary of geology (2d ed.): Falls Church, American Geological Institute, $751 \mathrm{p}$.

Beaty, C.B., 1959, Slope retreat by gullying: Geological Society of America Bulletin, v. 70, p. 1479-1482.

Blaskowski, M.J., Loen, J.S., and Elliott, J.E., 1983, Map showing geology and mineral deposits of the southern part of the Alder Gulch quadrangle, Granite County, Montana: U.S. Geological Survey Open-File Report 83-414, scale $1: 10,000$.

Boyle, R.W., 1979, The geochemistry of gold and its deposits: Geological Survey of Canada Bulletin 280, 584 p.

Bryan, Kirk, 1940, Gully gravure-a method of slope retreat: Journal of Geomorphology, v. 3, p. 87-107.

Choate, Raoul, 1962, Geology and ore deposits of the Stanley area: Idaho Bureau of Mines and Geology Pamphlet No. $126,122 \mathrm{p}$.

Dietrich, W.E., and Dorn, Ronald, 1984, Significance of thick deposits of colluvium on hillslopes-A case study involving the use of pollen analysis in the coastal mountains of northern California: Journal of Geology, v. 92, p. 147-158.

Dietrich, W.E., and Dunne, Thomas, 1978, Sediment budget for a small catchment in mountainous terrain: Zeitschrift fur Geomorphologie, Supplement Band 29, p. 191-206. 
Dietrich, W.E., Humphrey, N.F., and Reid, L.M., 1982, Construction of sediment budgets for drainage basins, in Swanson, F.J., Janda, R.J., Dunne, Thomas, and Swanston, D.N., eds., Sediment budgets and routing in forested drainage basins: U.S. Forest Service General Technical Report PNW-141, p. 5-23.

Diller, J.S., 1914, Mineral resources of southwest Oregon: U.S. Geological Survey Bulletin 546, 147 p.

Ferguson, H.G., 1917, Placer deposits of the Manhattan district, Nevada: U.S. Geological Survey Bulletin 640-J, p. 163-193.

1922, The Round Mountain district, Nevada: U.S. Geological Survey Bulletin 725-I, p. 383-406.

Hill, J.M., 1910, Notes on the placer deposits of Greaterville, Arizona: U.S. Geological Survey Bulletin 430, p. 11-22.

Hite, T.H., 1933, Fine gold and platinum of Snake River, Idaho: Economic Geology, v. 28, no. 3, p. 256-265.

Hubbard, C.R., 1957, Mineral resources of Latah County, Idaho: Idaho Bureau of Mines and Geology County Report No. 2, $29 \mathrm{p}$.

Hughes, G.T., 1971, Petrology and tectonic setting of igneous rocks in the Henderson-Willow Creek igneous belt, Granite County, Montana: Houghton, Michigan Technological University, Ph.D. dissertation, 236 p.

1975, Relationship of igneous rocks to structure in the Henderson-Willow Creek igneous belt, Montana: Northwest Geology, v. 4, p. 15-25.

Jenkins, O.P., 1935, New technique applicable to study of placers: California Division of Mines and Geology State Mineralogist Report, v. 31, no. 2, 210 p.

Jones, E.L., 1916, Gold deposits near Quartzite, Arizona: U.S. Geological Survey Bulletin 620, p. 45-150.

Lehre, A.K., 1982a, Sediment mobilization and production from a small mountain catchment, Lone Tree Creek, Marin County, California: Berkeley, University of California, Ph.D. dissertation, 375 p.

$1982 \mathrm{~b}$, Sediment budget of a small coast range drainage basin in northcentral California, in Swanson, F.J., Janda, R.J., Dunne, Thomas, and Swanston, D. N., eds., Sediment budgets and routing in forested drainage basins: U.S. Forest Service General Technical Report PNW-141, p. 67-77.

Lingren, Waldemar, 1933, Mineral deposits (4th ed.): New York, McGraw-Hill, 930 p.

Loen, J.S., Blaskowski, M.J., and Elliott, J.E., Chapter A,
Gold placer deposits and a molybdenum anomaly in the Miners Gulch area, Granite County, Montana in Geology and mineral deposits of the Miners Gulch area, Granite County, Montana: U.S. Geological Survey Bulletin 1791.

Lorain, S.H., and Metzger, O.H., 1939, Reconnaissance of placer-mining districts in Lemhi County, Idaho: U.S. Bureau of Mines Information Circular 7082, 81 p.

Lyden, C.J., 1948, The gold placers of Montana: Montana Bureau of Mines and Geology Memoir 26, 152 p.

Macdonald, E.H., 1983, Alluvial mining, the geology, technology and economics of placers: New York, Chapman and Hall, 495 p.

Mackin, J.H., and Schmidt, D.L., 1956, Uranium- and thorium-bearing minerals in placer deposits in Idaho: International Conference on the Peaceful Uses of Atomic Energy, v. 6, p. 587-592.

Marron, D.C., 1982, Hillslope evolution and the genesis of colluvium in Redwood National Park, northwestern California - the use of soil development in their analysis: Berkeley, University of California, Ph.D. dissertation, $187 \mathrm{p}$.

Mills, H.H., 1981, Boulder deposits and the retreat of mountain slopes, or "gully gravure" revisited: Journal of Geology, v. 89, p. 649-660.

Pardee, J.T., 1933, Placer deposits of the western United States, in Ore deposits of the Western States (Lingren volume): American Institute of Mining and Metallurgical Engineers, p. 410-450.

Parker, B.H., Jr., 1974, Gold placers of Colorado: Colorado School of Mines Quarterly, v. 69, no. 3, 268 p., no 4. 224 p.

Pierson, T.C., 1980, Piezometric response to rainstorms in forested hillslope drainage depressions: Journal of Hydrology, v. 19, p. 1-10.

Shenon, P.J., 1933, Geology and ore deposits of the TakilmaWaldo district, Oregon, including the Blue Creek district: U.S. Geological Survey Bulletin 846-B, p. 141-194.

Swanson, F.J., and Fredriksen, R.L., 1982, Sediment routing and budgets-implications for judging impact of forestry practices, in Swanson, F. J., Janda, R.J., Dunne, Thomas, and Swanston, D.N., eds., Sediment budgets and routing in forested drainage basins: U.S. Forest Service General Technical Report PNW-141, p. 129-137.

Wolman, M.G., and Miller, J.P., 1960, Magnitude and frequency of forces in geomorphic processes: Journal of Geology, v. 68 , p. 54-74. 